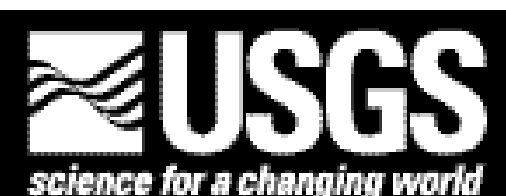

science for a changing world

\title{
The Niger Delta Petroleum System: Niger Delta Province, Nigeria, Cameroon, and Equatorial Guinea, Africa
}

by Michele L. W. Tuttle, ${ }^{1}$ Ronald R. Charpentier, ${ }^{1}$ and Michael E. Brownfield $^{1}$

Open-File Report 99-50-H

1999

This report is preliminary and has not been reviewed for conformity with U.S. Geological Survey editorial standards or with the North American Stratigraphic Code. Any use of trade, firm, or product names is for descriptive purposes only and does not imply endorsement by the U.S. Government.

\section{U.S. DEPARTMENT OF THE INTERIOR}

U.S. GEOLOGICAL SURVEY

${ }^{1}$ Denver, Colorado 


\section{The Niger Delta Petroleum System: Niger Delta Province, Nigeria Cameroon, and Equatorial Guinea, Africa}

by Michele L. W. Tuttle, Ronald R. Charpentier, and Michael E. Brownfield

Open-File Report 99-50-H

1999

\section{CONTENTS}

Forward

by the U.S. Geological Survey World Energy Project

Chapter A. Tertiary Niger Delta (Akata-Agbada) Petroleum System (No. 719201), Niger Delta Province, Nigeria, Cameroon, and Equatorial Guinea, Africa by Michele L. W. Tuttle, Michael E. Brownfield, and Ronald R. Charpentier

Chapter B. Assessment of Undiscovered Petroleum in the Tertiary Niger Delta (Akata-Agbada) Petroleum System (No. 719201), Niger Delta Province, Nigeria, Cameroon, and Equatorial Guinea, Africa

by Michele L. W. Tuttle, Ronald R. Charpentier, and Michael E. Brownfield

Chapters A and B are issued as a single volume and are not available separately. 


\section{TABLE OF CONTENTS}

Page

Forward, by the U.S. Geological Survey World Energy Project 1

Chapter A. Tertiary Niger Delta (Akata-Agbada) Petroleum System (No. 719201), Niger Delta Province, Nigeria, Cameroon, and Equatorial Guinea, Africa

by Michele L. W. Tuttle, Michael E. Brownfield, and Ronald R. Charpentier

Page

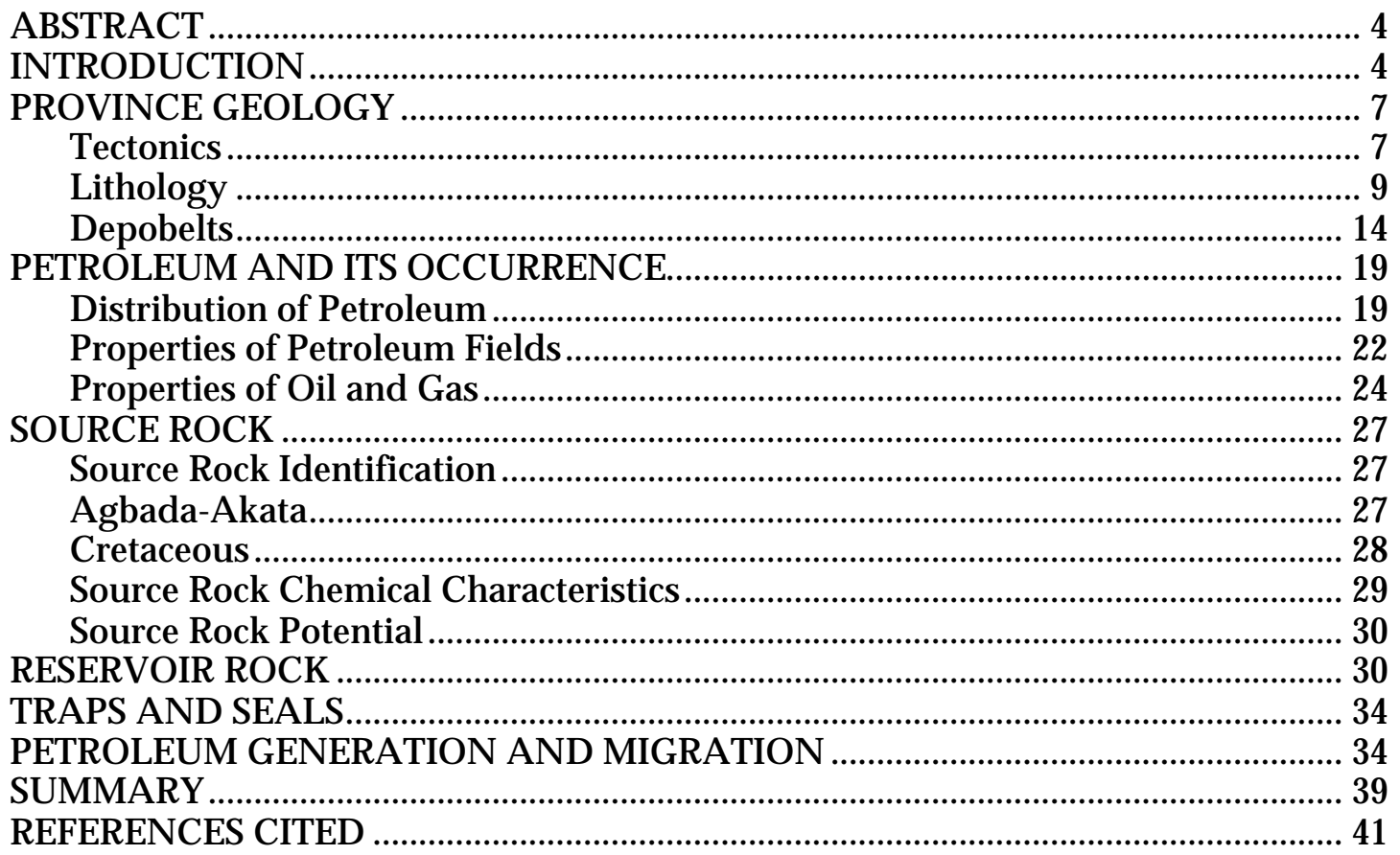

\section{FIGURES}

Figure 1. Index map of Nigeria and Cameroon. Map of the Niger Delta showing Province outline, bounding structural features, and minimum petroleum system.

Figure 2. Cross plots for cumulative number of oil and gas fields versus cumulative number of total new-field wildcat wells in the Niger Delta Province. 
Figure 3. Paleogeographic maps showing the opening of the South Atlantic and development of the region around Niger Delta....

Figure 4. Schematic of a seismic section from the Niger Delta continental slope/rise showing the results of internal gravity tectonics on sediments at the distal portion of the depobelt.....

Figure 5. Stratigraphic section of the Anambra Basin from the Late Cretaceous through the Eocene.

Figure 6. Location map cross sections through the Niger Delta Region ..................... 15

Figure 7. Stratigraphic column showing the three formations of the Niger Delta.

Figure 8. Structural map of the top of Akata Formation and thickness isopach of Agbada Formation.

Figure 9. Cartoon showing how the coastline of the Niger delta has prograded since $35 \mathrm{Ma}$.

Figure 10. Schematic showing the location of lobes of the early Niger Delta, prolific

oil centers, and shale prone areas ............................................................................ 21

Figure 11. Sequence stratigraphic model for the central portion of the Niger Delta. 23

Figure 12. Distribution of size and mean reservoir depth of Niger Delta oil and gas fields

Figure 13. Geochemical data for nonbiodegraded oil (A) and a partially biodegraded oil (B) from the Niger Delta .......................................................................................... 26

Figure 14. Physiographic sketch of the deep marine sediments in the Gulf of Guinea off the Niger Delta.

Figure 15. Slope-Edge normal fault simulation, Nigerian example ............................. 33

Figure 16. Examples of Niger Delta oil field structures and associated trap types ... 35

Figure 17. Subsurface depth to top of Niger Delta oil...................................................... 36

Figure 18. Burial history chart for the northern portion of the Niger Delta (Akata-Agbada) petroleum system

Figure 19. Events chart for Niger Delta (Akata/Agbada) petroleum system

Chapter B. Assessment of Undiscovered Petroleum in the Tertiary Niger Delta (Akata-Agbada) Petroleum System (No. 719201), Niger Delta Province, Nigeria, Cameroon, and Equatorial Guinea, Africa

by Michele L. W. Tuttle, Ronald R. Charpentier, and Michael E. Brownfield

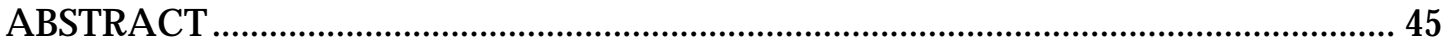

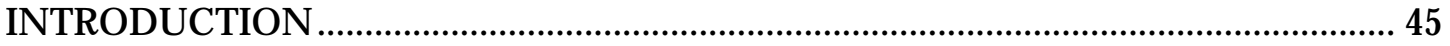

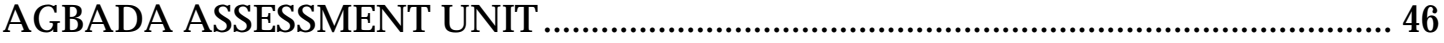

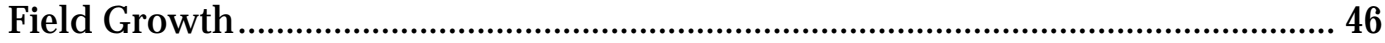

Exploration for Undiscovered Petroleum ....................................................... 46 
Assumptions for Assessing Undiscovered Resources........................................ 47

Assessment of Undiscovered Petroleum ............................................................. 53

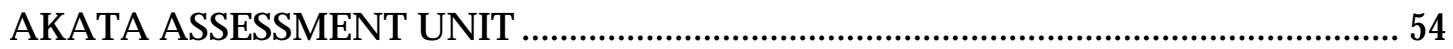

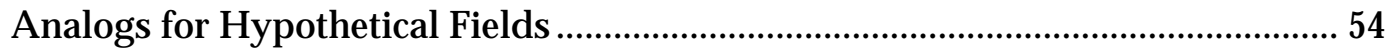

Assessment of Undiscovered Petroleum .................................................................... 55

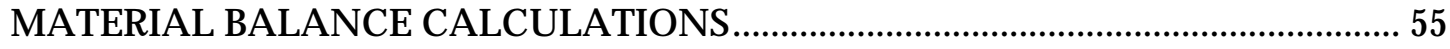

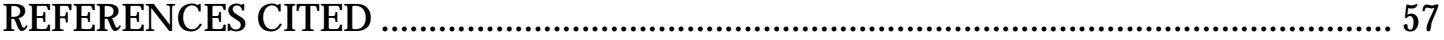

\section{FIGURES}

Figure 1. Map showing the boundaries of the Agdada "Deltaic"

Reservoir Assessment Unit and the Akata "Turbidite" Reservoir Assessment

Unit

Figure 2. Cross plots for cumulative number of (A) oil fields and (B)

gas fields versus cumulative number of total new-field wildcat

wells in the Niger Delta Province.......................................................................... 49

Figure 3. Crossplots for cumulative volume of discovered (A) oil fields (MMB0) and

(B) gas fields (BCFG) versus cumulative number of

new-field wildcat wells in the Niger Delta Province.

Figure 4. Histogram showing the grown oil field size divided into first third, second third, and third third of the oil fields discovered in the Niger Delta

Figure 5. Histogram showing the grown gas field size divided into first third, second third, and third third of the gas fields discovered in the Niger Delta

\section{APPENDICES}

Appendix A. Input for Monte Carlo Simulations of the Agbada and the Akata Assessment Units

Appendix B. Summary of the results from the Monte Carlo

simulations 


\section{Foreword}

\section{By the U.S. Geological Survey World Energy Project}

This report was prepared as part of the World Energy Project of the U.S. Geological Survey's Energy Resources Program. The purpose of this effort is to assess the quantities of oil, gas, and natural gas liquids that have the potential to be added to reserves within the next 30 years. These volumes either reside in undiscovered fields whose sizes exceed the minimum-field-size cutoff value (variable, but at least 1 million barrels of oil equivalent), or occur as reserve growth of fields already discovered.

To organize, evaluate, and delineate areas to assess, a hierarchical scheme of geographic and geologic units was developed. These are regions, geologic provinces, petroleum systems, and assessment units. In the World Energy Project, regions serve as organizational units and geologic provinces are used as prioritization tools

The project divided the world into eight regions and 937 geologic provinces. Provinces were ranked according to the discovered oil and gas volumes within each (Klett and others, 1997). Seventy-six "priority" provinces (exclusive of the U.S. and chosen for their high ranking) and 26 "boutique" provinces (exclusive of the U.S. and chosen for their anticipated petroleum richness or special regional economic or strategic importance) were selected for appraisal of oil and gas resources. The petroleum geology and assessment results of priority and boutique provinces are described in a series of reports, including the following two chapters.

A geologic province is an area having characteristic dimensions of hundreds of kilometers that encompasses a natural geologic entity (for example, sedimentary basin, thrust belt, accreted terrain) or some combination of contiguous geologic entities. Province boundaries were drawn as logically as possible along natural geologic boundaries, although, in some places, their location is based on other factors such as a specific bathymetric depth in open oceans.

Petroleum systems and assessment units are delineated within each of the geologic provinces assessed for undiscovered oil and gas. Although the boundaries of petroleum systems and assessment units are usually contained within a geologic province, it is not required. The total petroleum system concept emphasizes the oils that come from a common source (Magoon and Dow, 1994), unlike geologic provinces and plays that emphasize similarities in the rocks and structural characteristics. The mapped area of the petroleum system includes all genetically related petroleum that occurs in shows and accumulations (discovered and undiscovered) generated by a pod of mature source rock. The area also includes the essential geologic elements (i.e. reservoirs, seals, traps, and overburden rocks) that control the fundamental processes of petroleum occurrence-generation, expulsion, migration, entrapment, and preservation. The "minimum" petroleum system is that part of a petroleum system encompassing discovered shows and accumulations together with the geologic space in which the various essential elements have been proved by these discoveries. 
An assessment unit is a portion of a petroleum system in which discovered and undiscovered fields constitute a single, relatively homogeneous population. ${ }^{1} \mathrm{~A}$ petroleum system might equate to a single assessment unit, or, if necessary, may be subdivided into two or more assessment units such that each assessment unit is sufficiently homogeneous in terms of geology, exploration considerations, and risk to assess individually. Heterogeneity cannot be alleviated in all assessment units. In such cases, uniform accumulation density and exploration concepts are not extrapolated across the entire assessment unit.

A numeric code identifies each region, province, petroleum system, and assessment unit; these codes are uniform throughout the project and throughout all publications of the project. The code is as follows:

Region (single digit)

Province (three digits to the right of region code)

Example

Petroleum system (two digits to the right of province code)

Assessment unit (two digits to the right of petroleum system code)

3

3162

316205

31620504

The codes for the regions and provinces are listed in Klett and others (1997).

Known oil and gas volumes (sum of cumulative production and estimated reserves) quoted in this report are derived from Petroconsultants, Inc. 1996 Petroleum Exploration and Production database (Petroconsultants, 1996) and other area reports from Petroconsultants, Inc., unless otherwise noted. Increases in reported estimated total recoverable volumes are commonly observed from year to year. To address this phenomenon, the U.S. Geological Survey has developed and adopted several "fieldgrowth" models and also uses the U.S. Minerals Management Service model. When applicable, a model is applied to the reported data and the resultant "grown" data, rather than the Petroconsultant's "known" data, are used in the assessment process.

Figures in this report that show boundaries of the petroleum system(s), assessment units, and pods of active source rocks were compiled using geographic information system (GIS) software. Political boundaries and cartographic representations were taken, with permission, from Environmental Systems Research Institute's ArcWorld 1:3 million digital coverage (Environmental Systems Research Institute, 1992). These are not politically definitive and are displayed for general reference only. Oil and gas field center points, shown on these figures, are reproduced, with permission, from Petroconsultants (1996).

\section{REFERENCES CITED IN FORWARD}

Environmental Systems Research Institute, 1992, ArcWorld 1:3M digital database: Environmental Systems Research Institute, Inc. (ESRI), available from ESRI, Redlands, CA, scale: 1:3,000,000.

\footnotetext{
${ }^{1}$ The methodology of our resource assessment is based on the probability of number and size of undiscovered fields and, therefore, is sensitive to the homogeneity of each population being assessed.
} 
Klett, T. R., Ahlbrandt, T. S., Schmoker, J. W., and Dolton, G. L., 1997, Ranking of the world's oil and gas provinces by known petroleum volumes: U. S. Geological Survey Open-File Report 97-463, CD-Rom.

Petroconsultants, 1996, Petroleum exploration and production database: Houston, Texas, Petroconsultants, Inc., [database available from Petroconsultants, Inc., P.O. Box 740619, Houston, TX 77274-0619]. 


\title{
Chapter A
}

\section{Tertiary Niger Delta (Akata-Agbada) Petroleum System (No. 701901), Niger Delta Province, Nigeria, Cameroon, and Equatorial Guinea, Africa}

\author{
by Michele L. W. Tuttle, Michael E. Brownfield, and Ronald R. \\ Charpentier
}

\begin{abstract}
In the Niger Delta province, we have identified one petroleum system--the Tertiary Niger Delta (Akata-Agbada) petroleum system. The delta formed at the site of a rift triple junction related to the opening of the southern Atlantic starting in the Late Jurassic and continuing into the Cretaceous. The delta proper began developing in the Eocene, accumulating sediments that now are over 10 kilometers thick. The primary source rock is the upper Akata Formation, the marine-shale facies of the delta, with possibly contribution from interbedded marine shale of the lowermost Agbada Formation. Oil is produced from sandstone facies within the Agbada Formation, however, turbidite sand in the upper Akata Formation is a potential target in deep water offshore and possibly beneath currently producing intervals onshore.

Known oil and gas resources of the Niger Delta rank the province as the twelfth largest in the world. To date, 34.5 billion barrels of recoverable oil and 93.8 trillion cubic feet of recoverable gas have been discovered. In 1997, Nigeria was the fifth largest crude oil supplier to the United States, supplying 689,000 barrels/day of crude.
\end{abstract}

\section{INTRODUCTION}

The Niger Delta is situated in the Gulf of Guinea (fig. 1) and extends throughout the Niger Delta Province as defined by Klett and others (1997). From the Eocene to the present, the delta has prograded southwestward, forming depobelts that represent the most active portion of the delta at each stage of its development (Doust and Omatsola, 1990). These depobelts form 

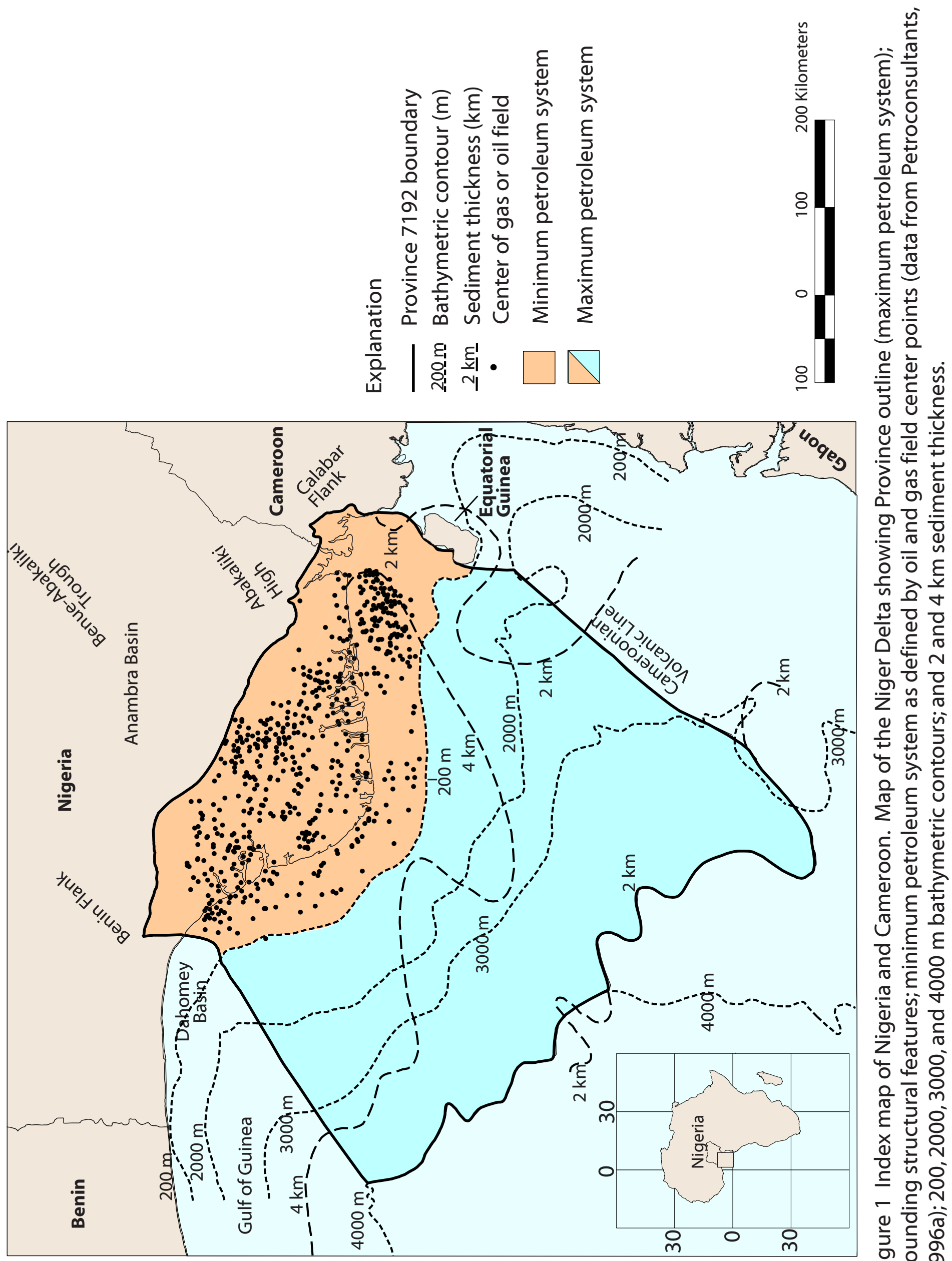

어음 늠

ᄃ 으 드

은 뜸

을

.

宅

ก)

핑 음

口 运

(1) $\frac{1}{0} \frac{N}{0}$

祭

(1) ह 느

范芠艺

을 ह

$\sum \frac{\hat{x}}{0} \cdot \frac{u}{4}$

ㄷํㅇ은

잉 눈

늘 을

ह ह

ชู

으 $\frac{1}{\sigma}$

๙ ह

- 즌 in

ฮั 을 음

之 른

ᄂ

음ㅎํ

है Ј

$\times$ 능

은 웅

드융

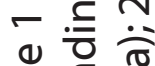

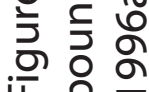


one of the largest regressive deltas in the world with an area of some 300,000 $\mathrm{km}^{2}$ (Kulke, 1995), a sediment volume of $500,000 \mathrm{~km}^{3}$ (Hospers, 1965), and a sediment thickness of over $10 \mathrm{~km}$ in the basin depocenter (Kaplan and others, 1994).

The Niger Delta Province contains only one identified petroleum system (Kulke, 1995; Ekweozor and Daukoru, 1994; this study). This system is referred to here as the Tertiary Niger Delta (Akata-Agbada) Petroleum System. ${ }^{1}$ The maximum extent of the petroleum system coincides with the boundaries of the province (fig. 1). The minimum extent of the system is defined by the areal extent of fields and contains known resources (cumulative production plus proved reserves) of 34.5 billion barrels of oil (BBO) and 93.8 trillion cubic feet of gas ${ }^{2}$ (TCFG) (14.9 billion barrels of oil equivalent, BBOE) (Petroconsultants, 1996a). Currently, most of this petroleum is in fields that are onshore or on the continental shelf in waters less than 200 meters deep (fig. 1), and occurs primarily in large, relatively simple structures. A few giant fields do occur in the delta, the largest contains just over 1.0 BBO (Petroconsultants, Inc., 1996a). Among the provinces ranked in the U.S. Geological Survey's World Energy Assessment (Klett and others, 1997), the Niger Delta province is the twelfth richest in petroleum resources, with $2.2 \%$ of the world's discovered oil and $1.4 \%$ of the world's discovered gas (Petroconsultants, Inc. 1996a).

In 1908, the German Nigerian Bitumen Corporation drilled the first wells in the vicinity of the tar seep deposits in the northern portion of the delta (Frost, 1997). However, significant oil shows were not found in Tertiary rocks until the early 1950's. Shell-British Petroleum brought the first well on stream in 1958 at 5,100 barrels per day. From 1958 until the Biafran War in 1967, exploration and production increased in Nigeria. The war curtailed both activities until its end in 1970, when world oil prices were rising and Nigeria again could benefit economically from its petroleum resources in the Niger Delta. In 1971, Nigeria joined the Organization of the Petroleum Exporting Countries (OPEC) with a total production of 703 million barrels of oil (MMBO) per annum.

In 1997, production rose to $810 \mathrm{MMBO}$ (Energy Information Administration, 1998a). Thirty-one percent of this production (251 MMBO) was exported to

\footnotetext{
${ }^{1}$ Akata-Agbada follows the petroleum system naming convention of Magoon and Dow (1994) where the petroleum system source rock is given first followed by the reservoir rock containing the largest volume of hydrocarbons.

${ }^{2}$ Reijers and others (1997) report natural gas reserves at 260 TCFG (46.3 BBOE). This is a near 2.5-fold increase that likely reflects the underreporting of gas in The Petroconsultant's Inc.'s database.
} 
the United States, making Nigeria the fifth largest supplier of U.S. oil. Despite the political uncertainty in Nigeria today, the country's sustainable production capacity is expected to increase over current production--they have agreed, however, to reduce their production by 225,000 barrels/day in 1998. Petroleum exploration is also expanding, especially in deeper water offshore, with the Nigerian government currently planning to offer six additional lease blocks in water up to $3000 \mathrm{~m}$ deep. Considering both oil and gas, the overall success ratio for exploration drilling is as high as $45 \%$ (Kulke, 1995; figs. 2A and 2B).

Exploration of the small portions of the Niger Delta in Cameroon and Equatorial Guinea began much later than in Nigeria. Recoverable oil and gas (produced plus proved reserves) are much smaller than in Nigeria. In 1997, $96 \%$ of the Niger Delta recoverable petroleum was in Nigeria, $3.5 \%$ in Cameroon, and 0.5\% in Equatorial Guinea (Petroconsultants, Inc., 1996a).

Acknowledgements. The authors wish to acknowledge T. Klett, F. Persits, and L. Osmonson of the U.S. Geological Survey for assistance with data and maps; .Petroconsultants Group and Geomark Research, Inc.; and L. Magoon, G. Ulmishek, and G. Dolton for thoughtful reviews of the manuscript.

\section{PROVINCE GEOLOGY}

The onshore portion of the Niger Delta Province is delineated by the geology of southern Nigeria and southwestern Cameroon (fig. 1). The northern boundary is the Benin flank--an east-northeast trending hinge line south of the West Africa basement massif. The northeastern boundary is defined by outcrops of the Cretaceous on the Abakaliki High and further east-south-east by the Calabar flank--a hinge line bordering the adjacent Precambrian. The offshore boundary of the province is defined by the Cameroon volcanic line to the east, the eastern boundary of the Dahomey basin (the eastern-most West African transform-fault passive margin) to the west, and the twokilometer sediment thickness contour or the 4000-meter bathymetric contour in areas where sediment thickness is greater than two kilometers to the south and southwest. The province covers $300,000 \mathrm{~km}^{2}$ and includes the geologic extent of the Tertiary Niger Delta (Akata-Agbada) Petroleum System.

\section{Tectonics}

The tectonic framework of the continental margin along the West Coast of equatorial Africa is controlled by Cretaceous fracture zones expressed as trenches and ridges in the deep Atlantic. The fracture zone ridges subdivide the margin into individual basins, and, in Nigeria, form the boundary faults of the Cretaceous Benue-Abakaliki trough, which cuts far into the West African shield. The trough represents a failed arm of a rift triple junction 

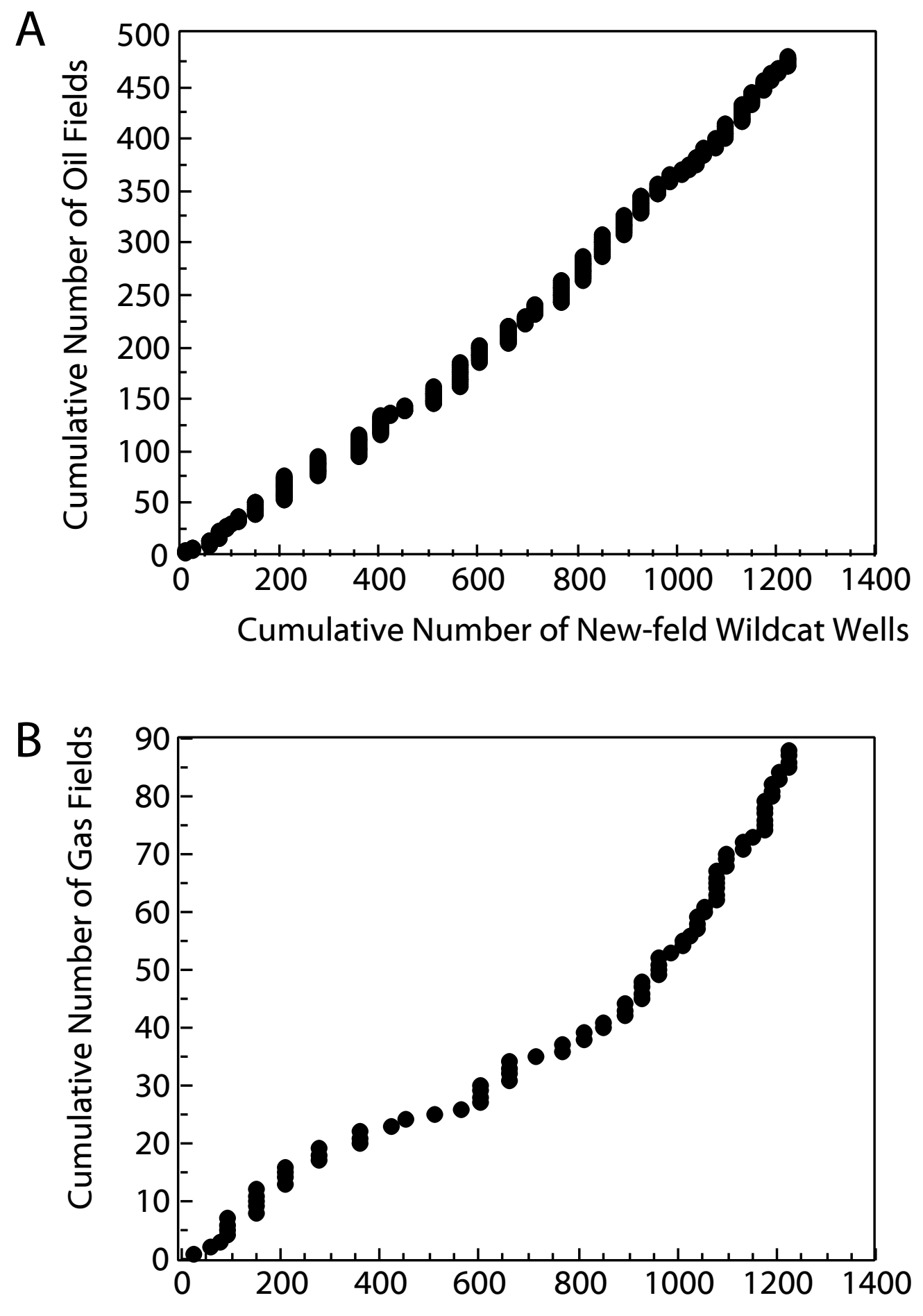

Cumulative Number of New-field Wildcat Wells

Figure 2. Crossplots for cumulative number of (A) oil fields and (B) gas fields versus cumulative number of total new-field wildcat wells in the Niger Delta Province. Data from Petroconsultants (1996a). 
associated with the opening of the South Atlantic. In this region, rifting started in the Late Jurassic and persisted into the Middle Cretaceous (Lehner and De Ruiter, 1977). In the region of the Niger Delta, rifting diminished altogether in the Late Cretaceous. Figure 3 shows the gross paleogeography of the region as well as the relative position of the African and South American plates since rifting began.

After rifting ceased, gravity tectonism became the primary deformational process. Shale mobility induced internal deformation and occurred in response to two processes (Kulke, 1995). First, shale diapirs formed from loading of poorly compacted, over-pressured, prodelta and delta-slope clays (Akata Fm.) by the higher density delta-front sands (Agbada Fm.). Second, slope instability occurred due to a lack of lateral, basinward, support for the under-compacted delta-slope clays (Akata Fm. ) (fig. 4). For any given depobelt, gravity tectonics were completed before deposition of the Benin Formation and are expressed in complex structures, including shale diapirs, roll-over anticlines, collapsed growth fault crests, back-to-back features, and steeply dipping, closely spaced flank faults (Evamy and others, 1978; Xiao and Suppe, 1992). These faults mostly offset different parts of the Agbada Formation and flatten into detachment planes near the top of the Akata Formation.

\section{Lithology}

The Cretaceous section has not been penetrated beneath the Niger Delta Basin, the youngest and southernmost sub-basin in the Benue-Abakaliki trough (Reijers and others, 1997). Lithologies of Cretaceous rocks deposited in what is now the Niger Delta basin can only be extrapolated from the exposed Cretaceous section in the next basin to the northeast--the Anambra basin (fig. 5). From the Campanian through the Paleocene, the shoreline was concave into the Anambra basin (Hospers, 1965) (see fig. 3 in this paper), resulting in convergent longshore drift cells that produced tide-dominated deltaic sedimentation during transgressions and river-dominated sedimentation during regressions (Reijers and others, 1997). Shallow marine clastics were deposited farther offshore and, in the Anambra basin, are represented by the Albian-Cenomanian Asu River shale, Cenomanian-Santonian Eze-Uku and Awgu shales, and Campanian/Maastrichtian Nkporo shale, among others (figs. 5 and 6) (Nwachukwu, 1972; Reijers and others, 1997). The distribution of Late Cretaceous shale beneath the Niger Delta is unknown

In the Paleocene, a major transgression (referred to as the Sokoto transgression by Reijers and others, 1997) began with the Imo shale being deposited in the Anambra Basin to the northeast and the Akata shale in the Niger Delta Basin area to the southwest (fig. 5). In the Eocene, the coastline shape became convexly curvilinear, the longshore drift cells switched to 


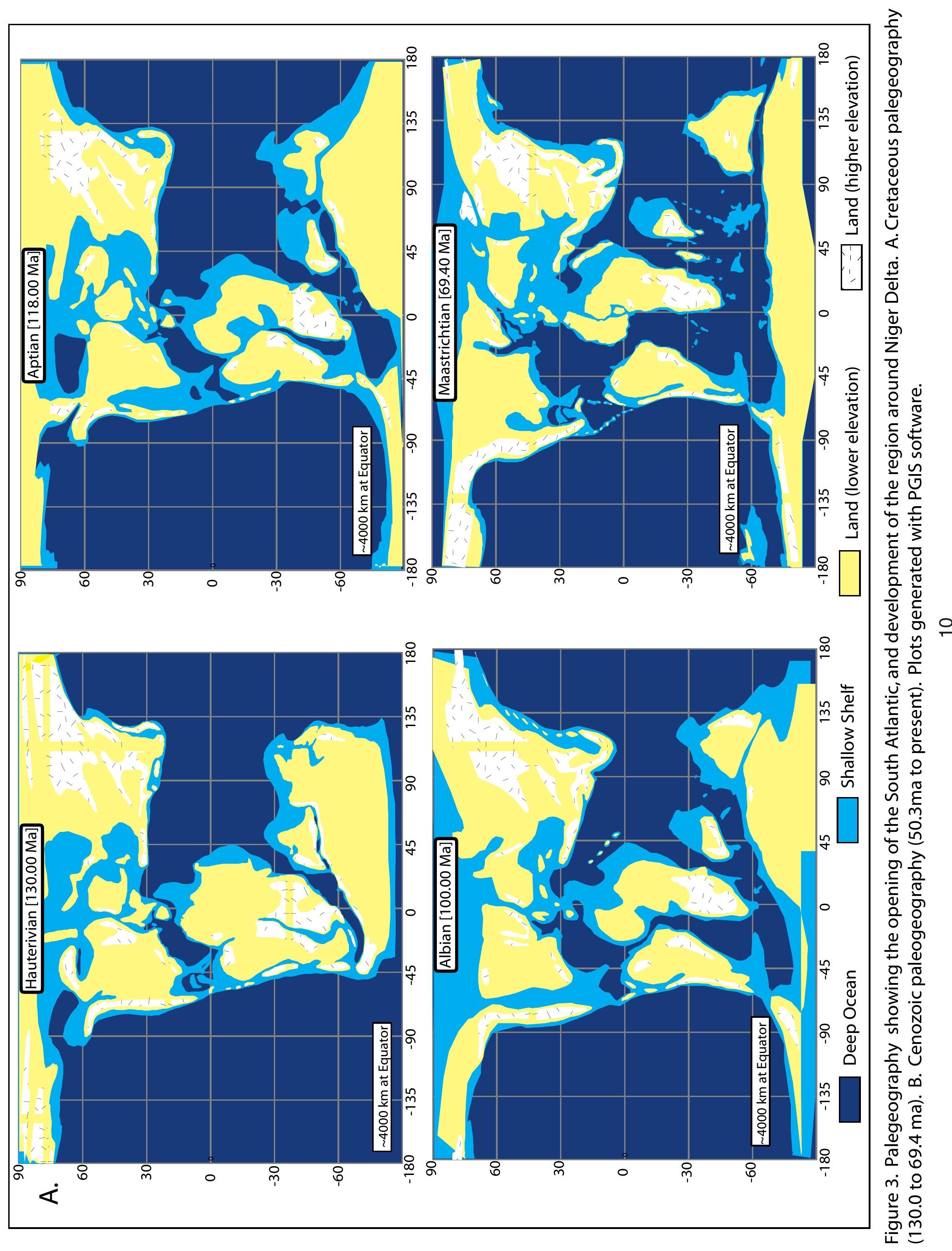



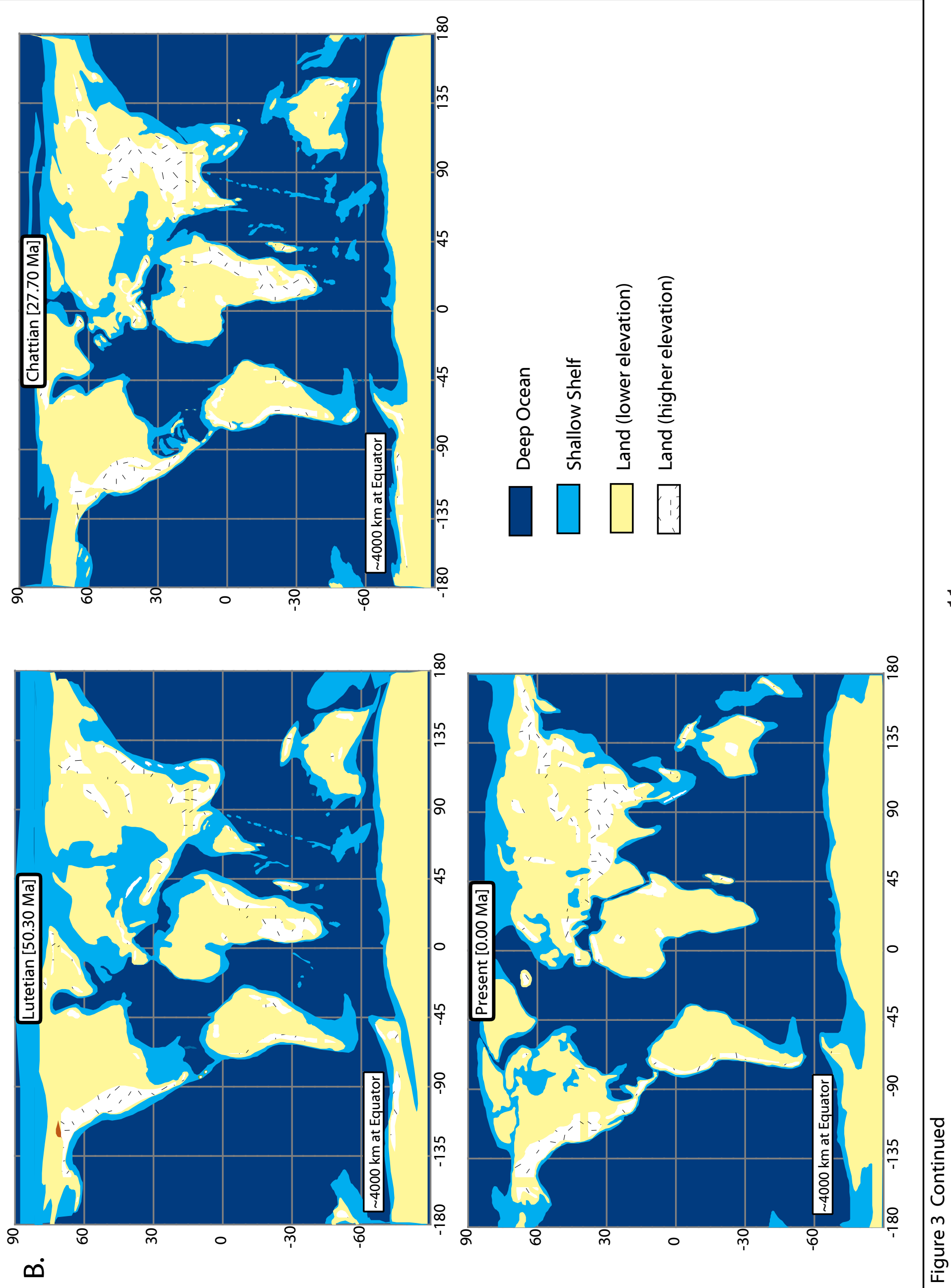


\section{Distal Portion of Depobelt}

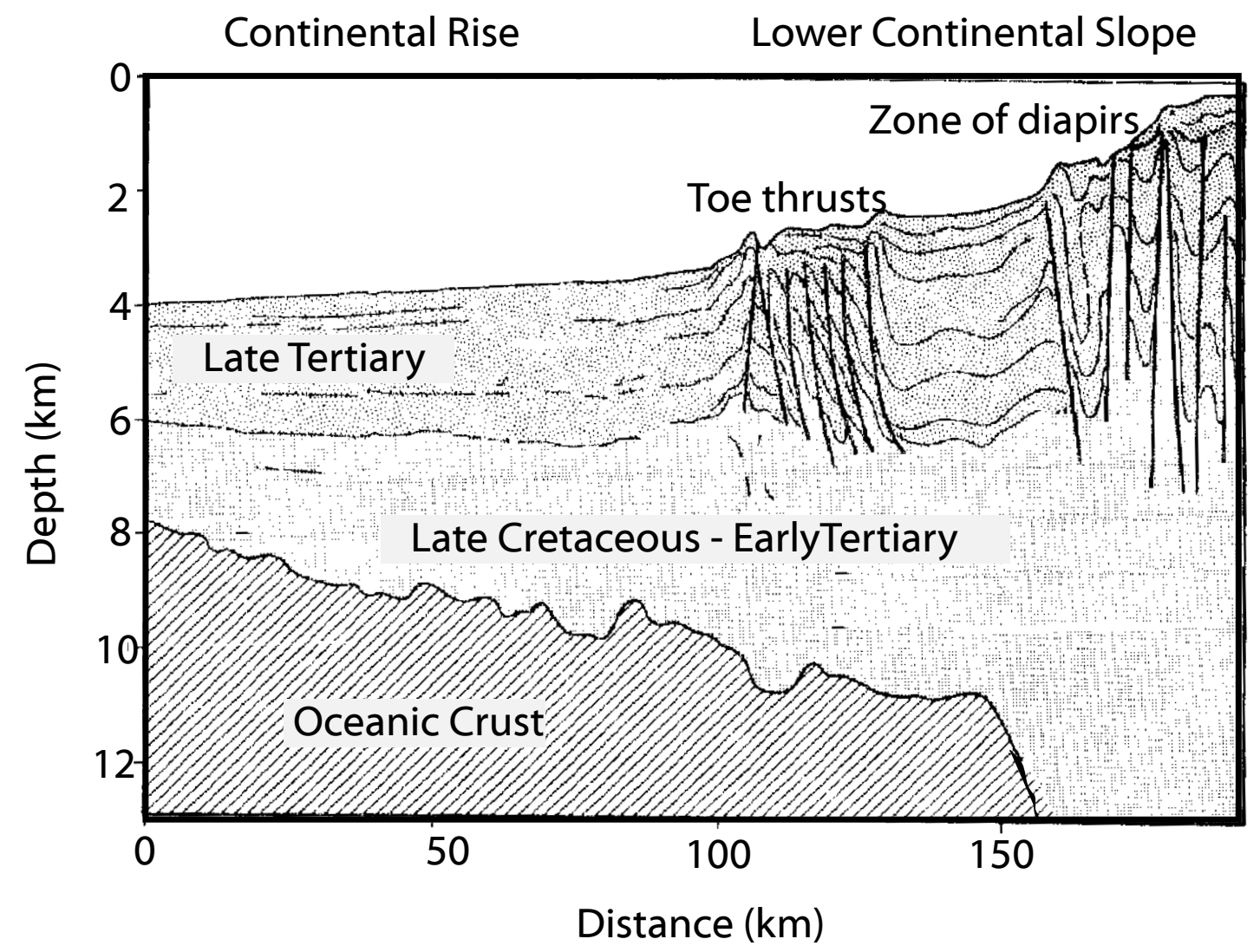

Figure 4. Schematic of a seismic section from the Niger Delta continental slope/ rise showing the results of internal gravity tectonics on sediments at the distal portion of the depobelt. The Late Cretaceous-Early Tertiary section has a lowvelocity gradient, probably marine shales, whereas the Late Tertiary has a normalvelocity gradient, suggesting a much sandier facies. Modified from Lehner and De Ruiter, 1977; Doust and Omatsola, 1990. 

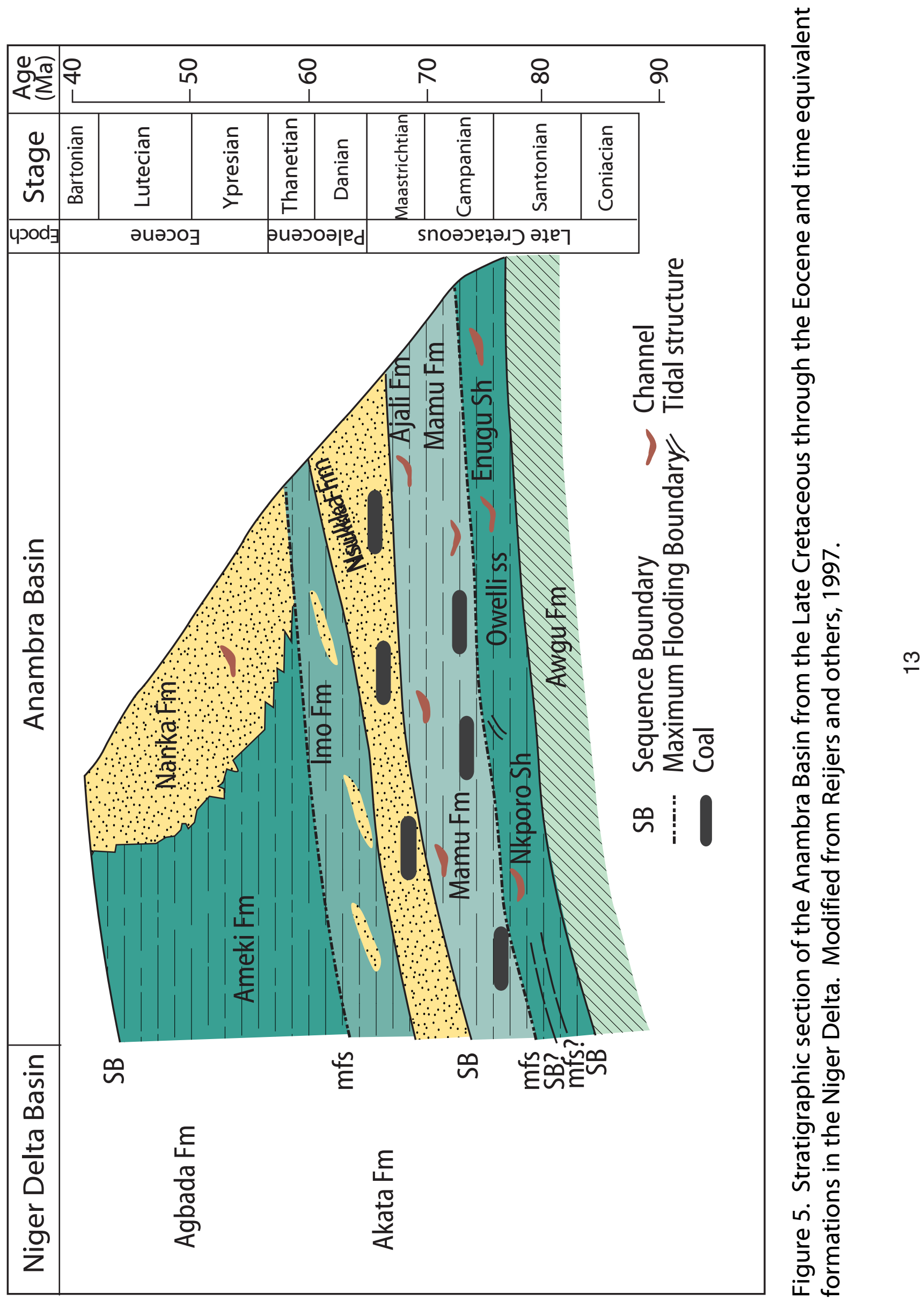
divergent, and sedimentation changed to being wave-dominated (Reijers and others, 1997). At this time, deposition of paralic sediments began in the Niger Delta Basin proper and, as the sediments prograded south, the coastline became progressively more convex seaward. Today, delta sedimentation is still wave-dominated and longshore drift cells divergent (Burke, 1972).

The Tertiary section of the Niger Delta is divided into three formations, representing prograding depositional facies that are distinguished mostly on the basis of sand-shale ratios. The type sections of these formations are described in Short and Stäuble (1967) and summarized in a variety of papers (e.g. Avbobvo, 1978; Doust and Omatola, 1990; Kulke, 1995). The Akata Formation at the base of the delta is of marine origin and is composed of thick shale sequences (potential source rock), turbidite sand (potential reservoirs in deep water), and minor amounts of clay and silt (figs. 5,6 and 7). Beginning in the Paleocene and through the Recent, the Akata Formation formed during lowstands when terrestrial organic matter and clays were transported to deep water areas characterized by low energy conditions and oxygen deficiency (Stacher, 1995). Little of the formation has been drilled; therefore, only a structural map of the top of the formation is available (fig. 8A). It is estimated that the formation is up to 7,000 meters thick (Doust and Omatsola, 1990). The formation underlies the entire delta, and is typically overpressured. Turbidity currents likely deposited deep sea fan sands within the upper Akata Formation during development of the delta (Burke, 1972).

Deposition of the overlying Agbada Formation, the major petroleum-bearing unit, began in the Eocene and continues into the Recent (figs. 5, 6, and 7). The formation consists of paralic siliciclastics over 3700 meters thick (Fig. 8B) and represents the actual deltaic portion of the sequence. The clastics accumulated in delta-front, delta-topset, and fluvio-deltaic environments. In the lower Agbada Formation, shale and sandstone beds were deposited in equal proportions, however, the upper portion is mostly sand with only minor shale interbeds. The Agbada Formation is overlain by the third formation, the Benin Formation, a continental latest Eocene to Recent deposit of alluvial and upper coastal plain sands that are up to $2000 \mathrm{~m}$ thick (Avbovbo, 1978).

\section{Depobelts}

Deposition of the three formations occurred in each of the five offlapping siliciclastic sedimentation cycles that comprise the Niger Delta. These cycles (depobelts) are 30-60 kilometers wide, prograde southwestward 250 kilometers over oceanic crust into the Gulf of Guinea (Stacher, 1995), and are defined by 

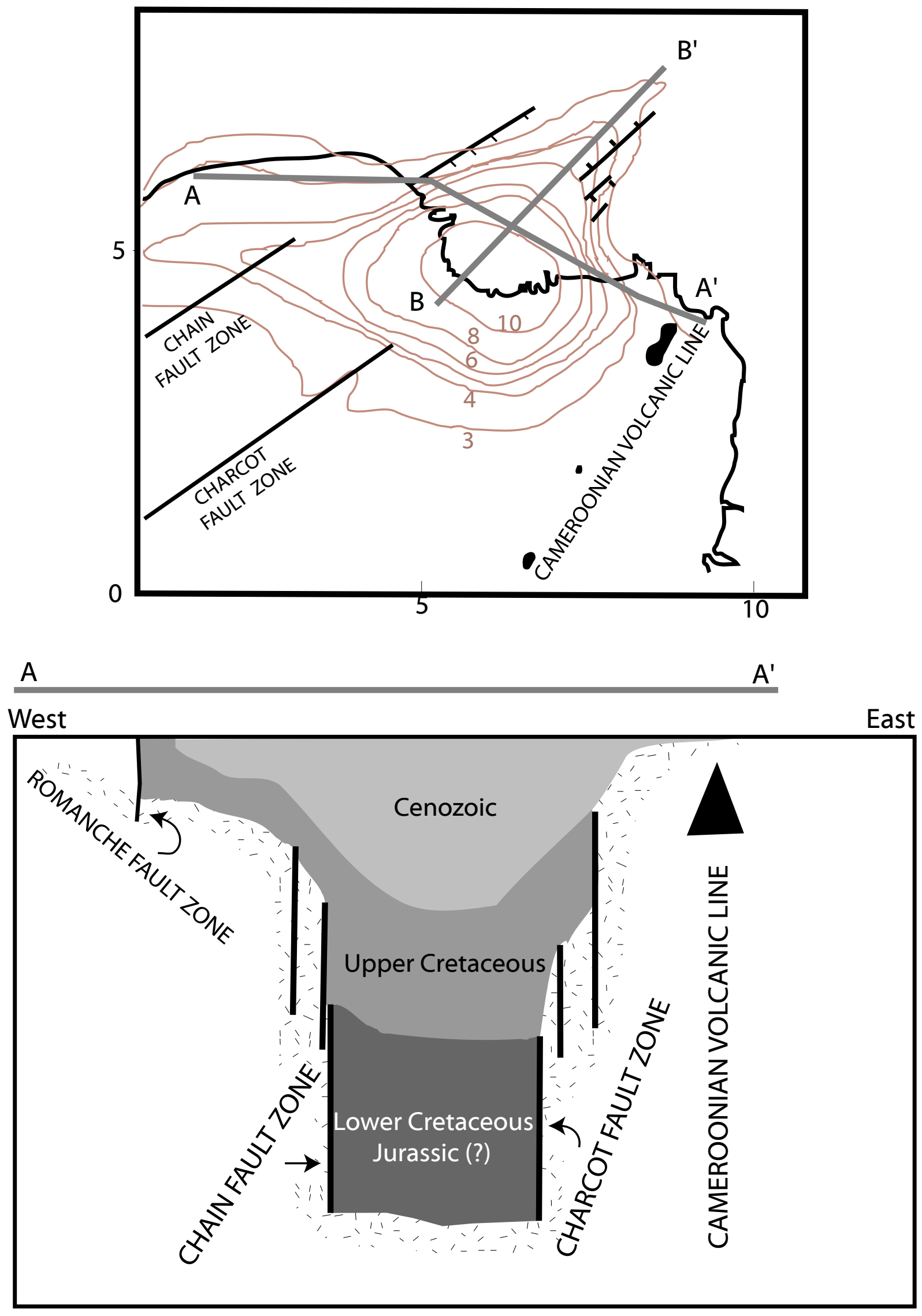

Figure 6. Diagrammatic east-west (A-A') cross section and southwest-northeast (B-B') cross section through the Niger Delta Region. Isopachs $(\mathrm{km})$ in location map are total sediment thickness (Kaplan and others, 1994). Stippled pattern in A-A', continental basement. Cross section A-A' and B-B' modified from Whiteman (1982). 

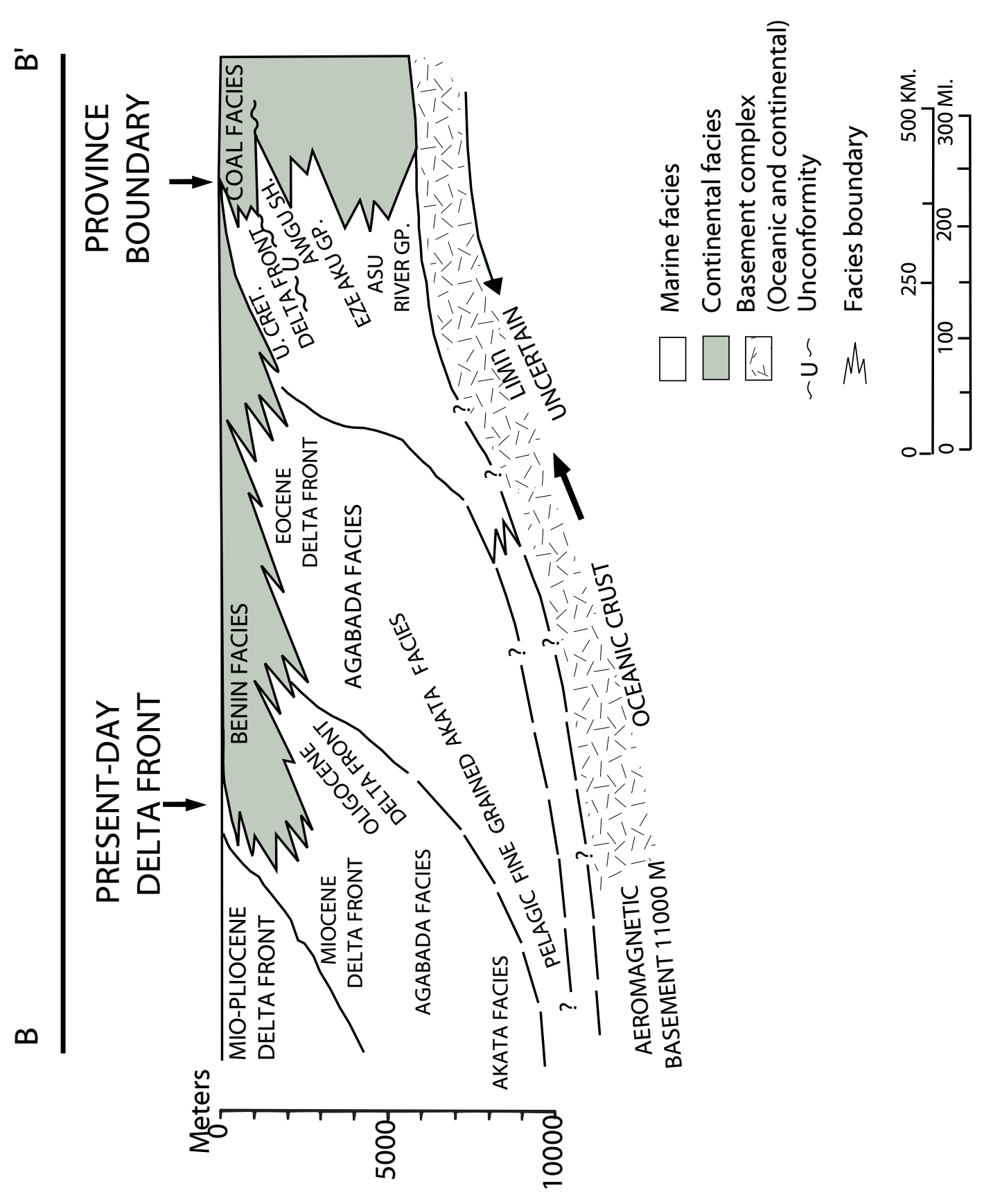

$\stackrel{\circ}{\circ}$ 


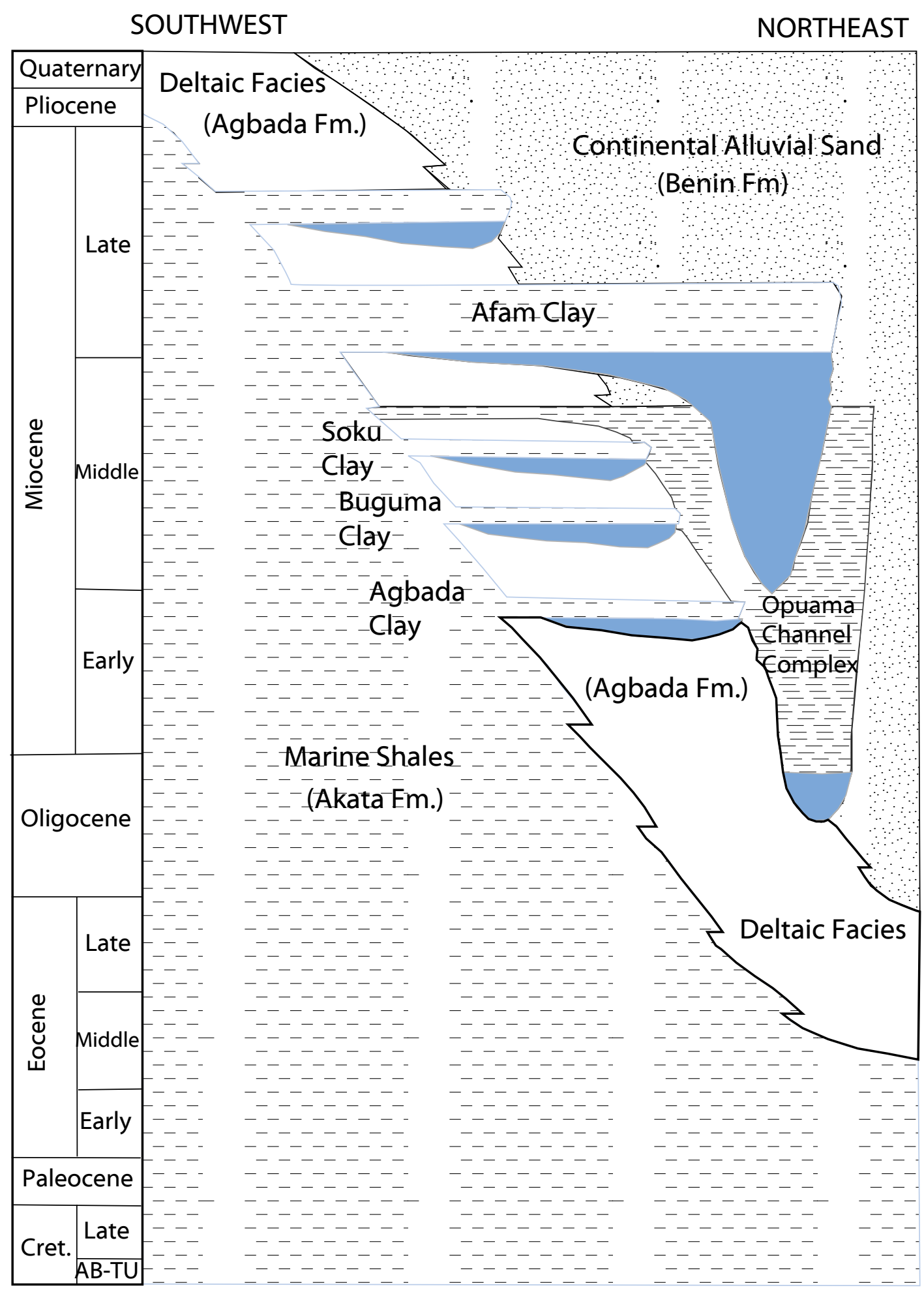

Extent of erosional truncation

Figure 7. Stratigraphic column showing the three formations of the Niger Delta. Modified from Shannon and Naylor (1989) and Doust and Omatsola (1990). 
A.

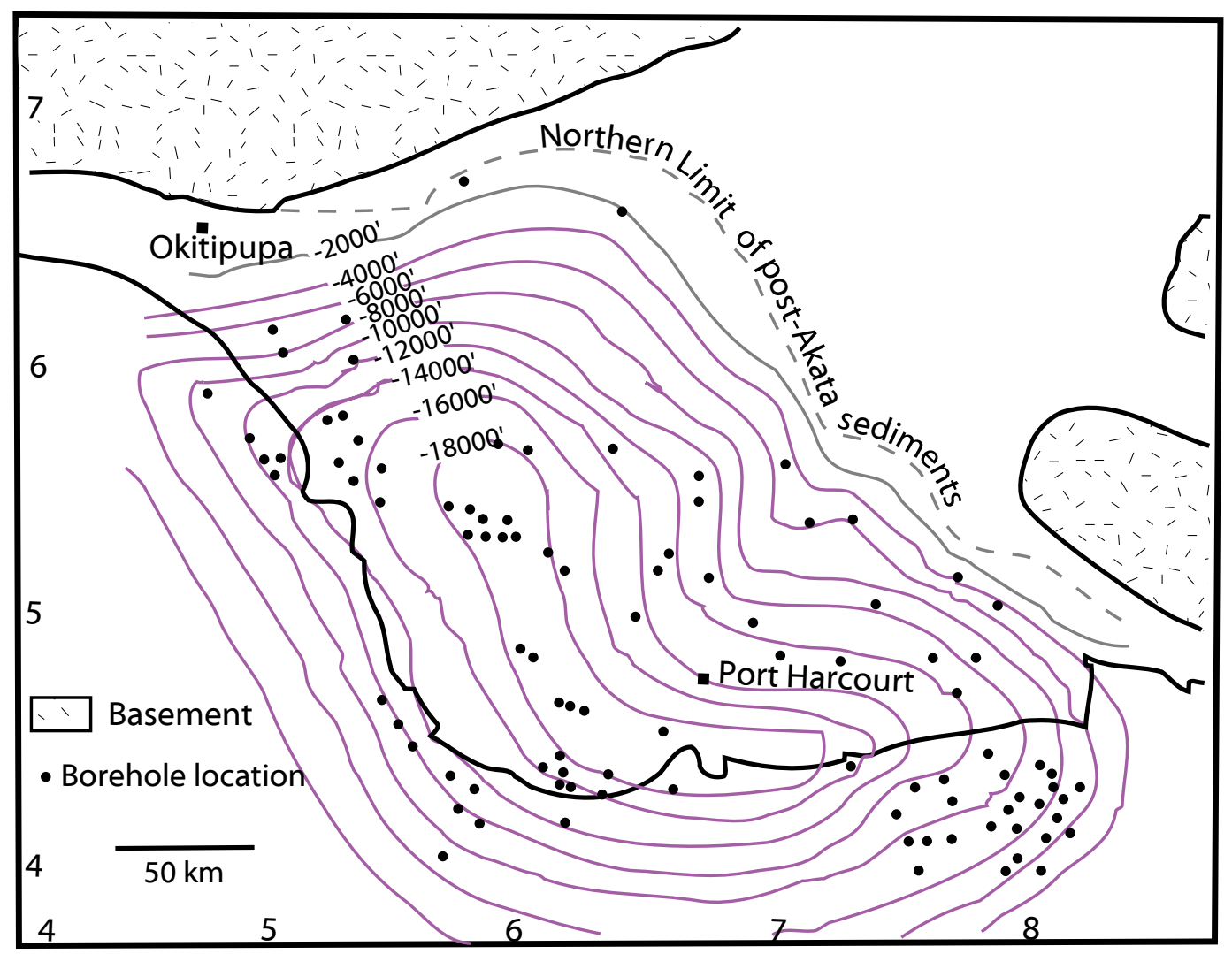

B.

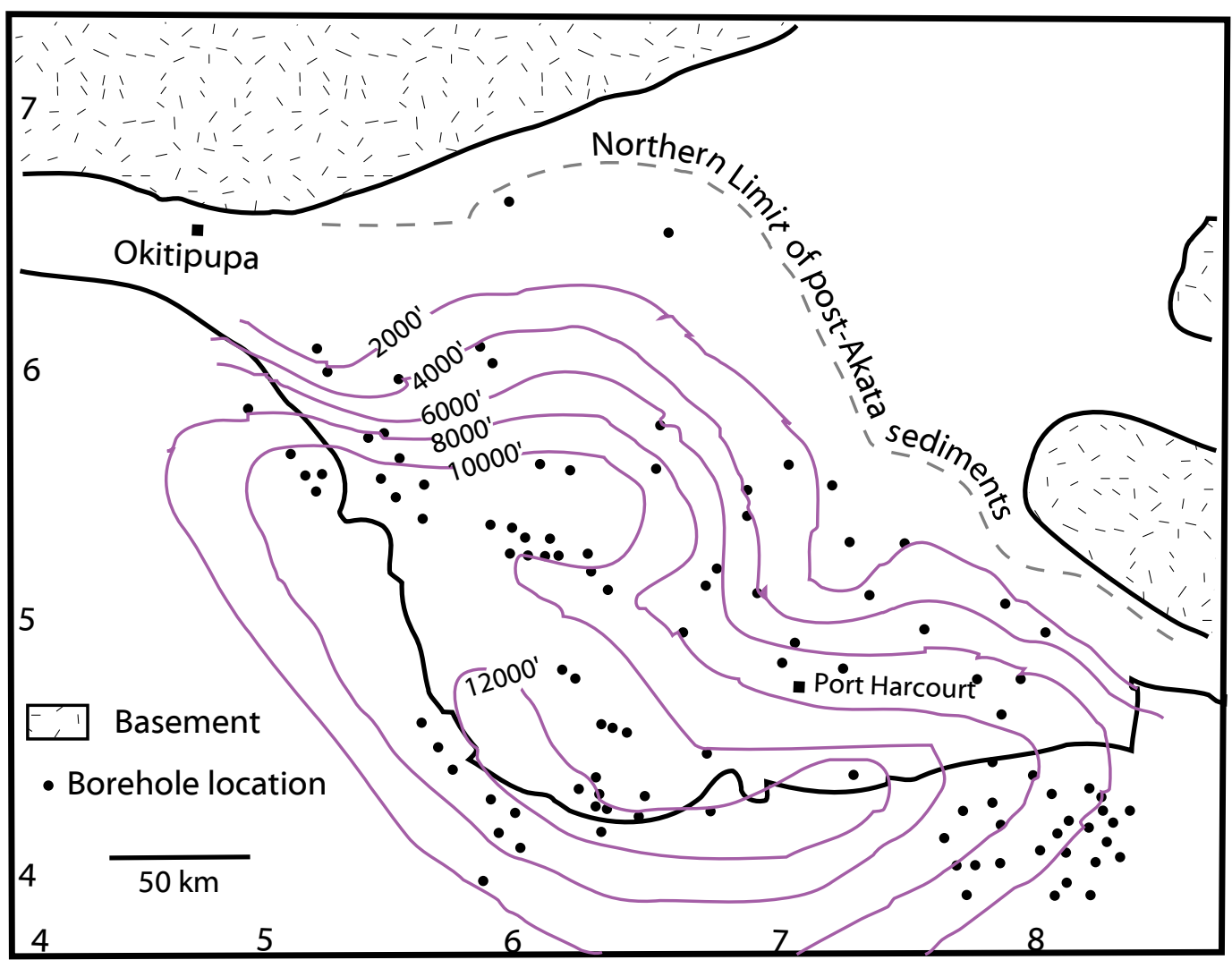

Figure 8. A structural map of the top of Akata Formation (A) and thickness isopach contours of the Agbada Formation (B). Contours in 2000 foot intervals. Modified from Avbovbo (1978). 
synsedimentary faulting that occurred in response to variable rates of subsidence $^{3}$ and sediment supply (Doust and Omatsola, 1990). The interplay of subsidence and supply rates resulted in deposition of discrete depobelts-when further crustal subsidence of the basin could no longer be accommodated, the focus of sediment deposition shifted seaward, forming a new depobelt (Doust and Omatsola, 1990). Each depobelt is a separate unit that corresponds to a break in regional dip of the delta and is bounded landward by growth faults and seaward by large counter-regional faults or the growth fault of the next seaward belt (Evamy and others, 1978; Doust and Omatsola, 1990). Five major depobelts are generally recognized, each with its own sedimentation, deformation, and petroleum history (fig. 9).

Doust and Omatsola (1990) describe three depobelt provinces based on structure. The northern delta province, which overlies relatively shallow basement, has the oldest growth faults that are generally rotational, evenly spaced, and increase their steepness seaward. The central delta province has depobelts with well-defined structures such as successively deeper rollover crests that shift seaward for any given growth fault. Last, the distal delta province is the most structurally complex due to internal gravity tectonics on the modern continental slope.

\section{PETROLEUM AND ITS OCCURRENCE}

\section{Distribution of Petroleum}

Petroleum occurs throughout the Agbada Formation of the Niger Delta (fig. 1), however, several directional trends form an "oil-rich belt" having the largest field and lowest gas:oil ratio (Ejedawe, 1981; Evamy and others; 1978; Doust and Omatsola, 1990). The belt extends from the northwest offshore area to the southeast offshore and along a number of north-south trends in the area of Port Harcourt (fig. 10). It roughly corresponds to the transition between continental and oceanic crust, and is within the axis of maximum sedimentary thickness (see isopach map in fig. 6). This hydrocarbon distribution was originally attributed to timing of trap formation relative to petroleum migration (earlier landward structures trapped earlier migrating oil). Evamy and others (1978), however, showed that in many rollovers, movement on the structure-building fault and resulting growth continued and was relayed progressively southward into the younger part of the section by successive crestal faults, concluding that there was no relation between growth along a fault and distribution of petroleum. Ejedawe (1981) relates the position of the oil-rich areas within the belt to five delta lobes fed by four different rivers. He states that the two controlling factors are an increase in

\footnotetext{
${ }^{3}$ Gravity field data from Hospers (1965) indicate that the Niger Delta is in near-isostatic equilibrium and represents a load accomodated by subsidence of the crust.
} 


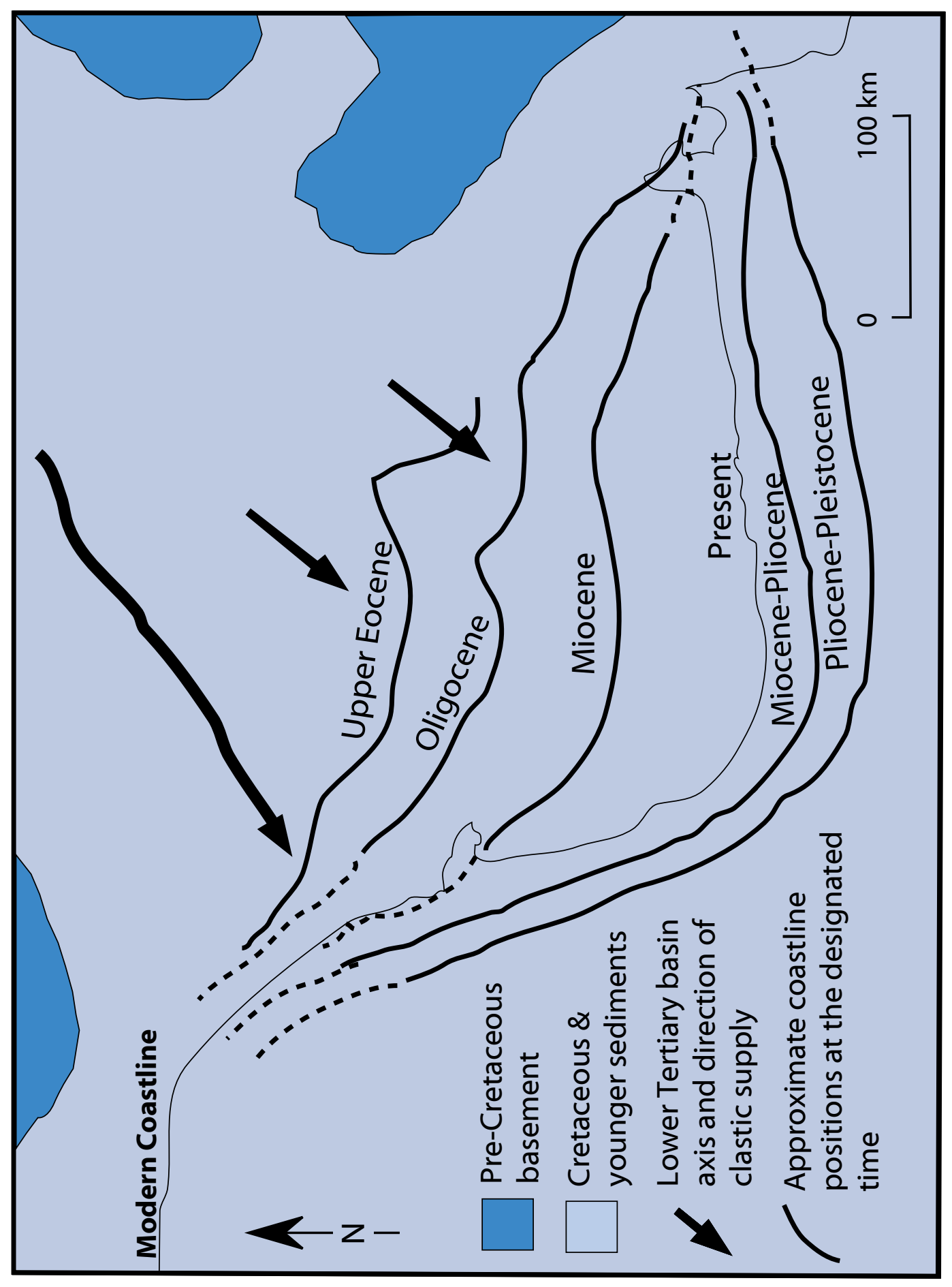

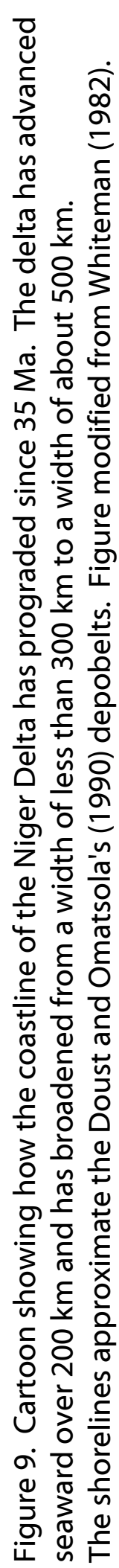




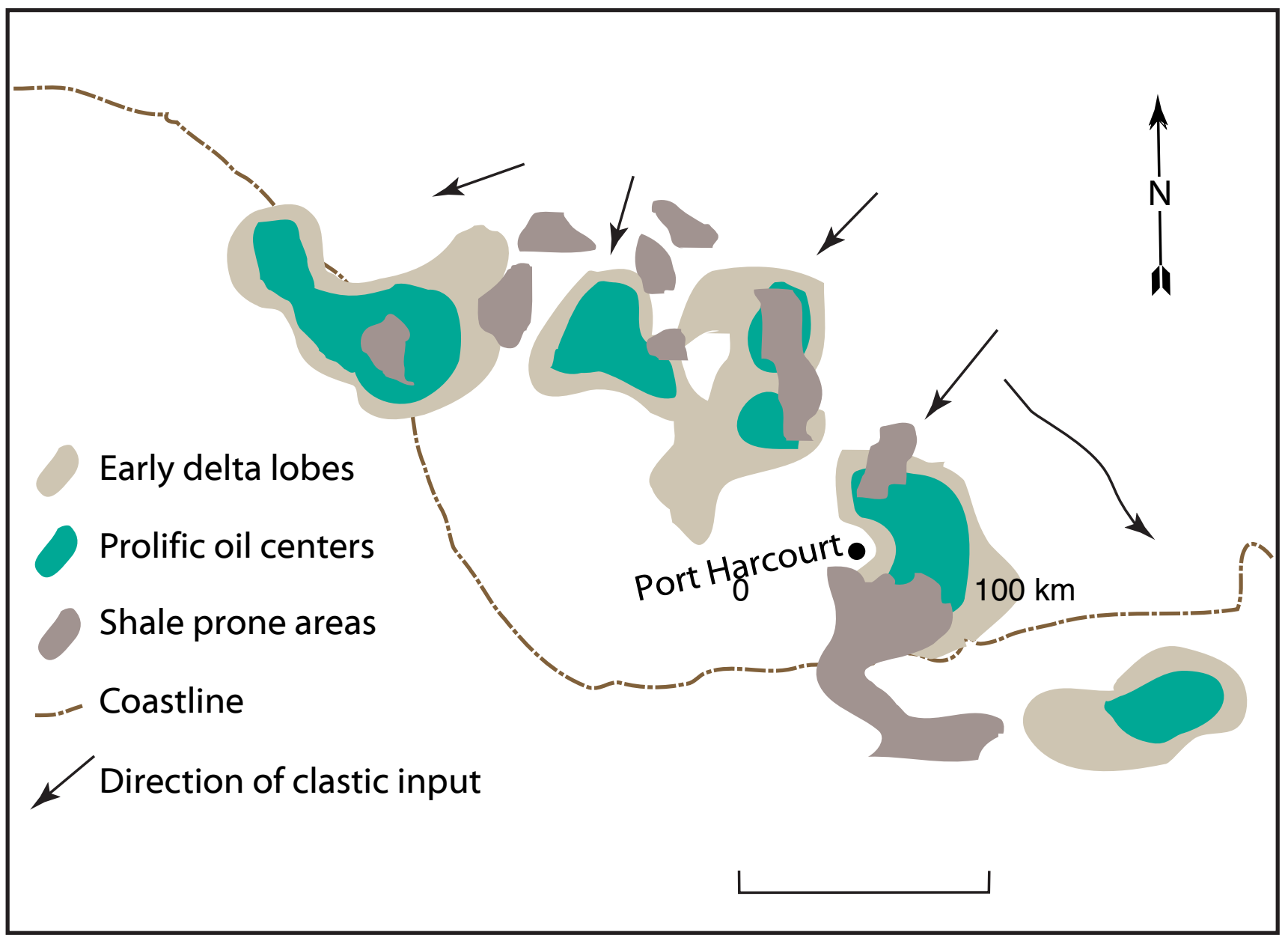

Figure 10. Schematic showing the location of lobes of the early Niger Delta, prolific oil centers, and shale prone areas. Modified from Ejedawe (1981) and Reijers and others (1997). 
geothermal gradient relative to the minimum gradient in the delta center and the generally greater age of sediments within the belt relative to those further seaward. Together these factors gave the sediments within the belt the highest "maturity per unit depth." Weber (1987) indicates that the oil-rich belt ("golden lane") coincides with a concentration of rollover structures across depobelts having short southern flanks and little paralic sequence to the south. Doust and Omatsola (1990) suggest that the distribution of petroleum is likely related to heterogeneity of source rock type (greater contribution from paralic sequences in the west) and / or segregation due to remigration. Haack and others (1997) relate the position of the oil-rich belt to oil-prone marine source rocks deposited adjacent to the delta lobes (fig. 10), and suggest that the accumulation of these source rocks was controlled by preTertiary structural sub-basins related to basement structures.

Outside of the "oil-rich belt" (central, easternmost, and northernmost parts of the delta), the gas:oil ratios (GOR) are high. The GOR within each depobelt increases seaward and along strike away from depositional centers. Causes for the distribution of GOR's are speculative and include remigration induced by tilting during the latter history of deposition within the downdip portion of the depobelt, updip flushing of accumulations by gas generated at higher maturity, and/or heterogeneity of source rock type (Doust and Omatsola, 1990).

Stacher (1995), using sequence stratigraphy, developed a hydrocarbon habitat model for the Niger Delta (fig. 11). The model was constructed for the central portion of the delta, including some of the oil-rich belt, and relates deposition of the Akata Formation (the assumed source rock) and the sand/shale units in the Agbada Formation (the reservoirs and seals) to sea level. Pre-Miocene Akata shale was deposited in deep water during lowstands and is overlain by Miocene Agbada sequence system tracts. The Agbada Formation in the central portion of the delta fits a shallow ramp model with mainly highstand (hydrocarbon-bearing sands) and trangressive (sealing shale) system tracts-third order lowstand system tracts were not formed. Faulting in the Agbada Formation provided pathways for petroleum migration and formed structural traps that, together with stratigraphic traps, accumulated petroleum. The shale in the transgressive system tract provided an excellent seal above the sands as well as enhancing clay smearing within faults.

\section{Properties of Petroleum Fields}

Most fields consist of a number of individual reservoirs that contain oil of varying composition with different gas/oil ratios. Gas caps are common. Many reservoirs are overpressured and primary production is mainly from gas expansion (Kulke, 1995). Common oil production problems include water coning, unconsolidated sands, wax deposition and high gas/oil ratios (see 


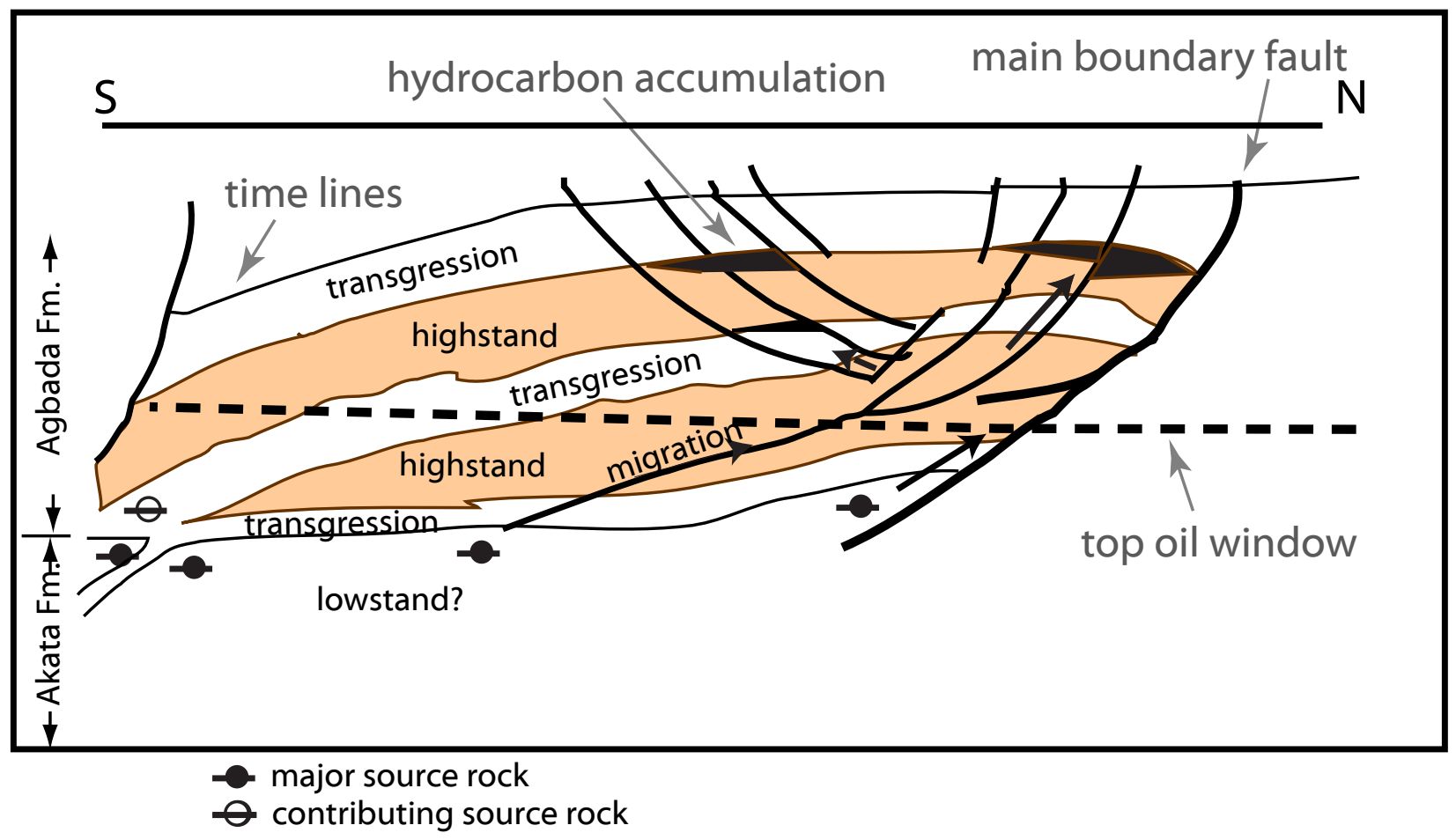

Figure 11. Sequence stratigraphic model for the central portion of the Niger Delta showing the relation of source rock, migration pathways and hydrocarbon traps related to growth faults. The main boundry fault separates megastructures which represent major breaks in the regional dip of the delta (Evamy and others, 1978). Figure is modified from Stacher (1995). 
below), leading to ultimate recovery rates up to 30\% (Kulke, 1995). The size and depth distribution of oil and gas fields is shown in Figure 12.

\section{Properties of Oil and Gas}

The physical and chemical properties of the oil in the Niger Delta are highly variable, even down to the reservoir level. Organic geochemical profiles for a nonbiodegraded and moderately biodegraded Niger Delta oil are summarized in Figure 13. The oil within the delta has a gravity range of $16-50^{\circ} \mathrm{API}$, with the lighter oils having a greenish-brown color (Whiteman 1982). Fifty-six percent of Niger Delta oils have an API gravity between $30^{\circ}$ and $40^{\circ}$ (Thomas, 1995). Most oils fall within one of two groups. The first group are light paraffin based, waxy oils from deeper reservoirs (wax content up to 20\%, but commonly around 5\%; Kulke, 1995; Doust and Omatsola, 1990; high nparaffin/naphthene of 0.86 , fig. 13). The second group of oils are biodegraded and from shallow reservoirs. They have lower API gravity (average API of $26^{\circ} ;$ Kulke, 1995) and are naphthenic non-waxy oils (n-paraffin $/$ naphthene $=$ 0.37 , fig. 13). Biodegradation and washing is extreme in some Pleistocene sands of the Agbada Formation, forming extra heavy oils (API 8-20 ${ }^{\circ}$ ). Oils with less than $25^{\circ}$ API account for only $15 \%$ of the Niger Delta reserves (Thomas, 1995). The concentration of sulfur in most oils is low, between 0.1 $\%$ and $0.3 \%$ (Mbendi, 1996), with a few samples having concentrations as high as $0.6 \%$ (Nwachukwu and others, 1995). A limited data set (Mbendi, 1996; Nwachuku and others, 1995) shows a negative correlation between API gravity and sulfur content, suggesting that sulfur content is likely related to oil degradation. This trend, however, is not seen in the data presented in Figure 13.

Oils derived from terrestrial organic matter such as those in the Niger Delta have high pristane:phytane ratios (fig. 13). If the oils are derived from terrestrial organic matter younger than mid-Cretaceous, then the oleanane: $C_{30}$-hopane ratios are high as well (fig. 13). ${ }^{4}$

Concentrations of $\mathrm{Ni}$ and $\mathrm{V}$ in Niger Delta oils are less than 100 and $\mathrm{V} /(\mathrm{V}+\mathrm{Ni})$ values range between 0.01 and 0.41 with an average of $0.12 \mathrm{ppm}$ (Nwachukwu and others, 1995), consistent with values in oils derived from Type III organic matter (Lewan and Maynard, 1982). Concentrations of sulfur and $\mathrm{V} /(\mathrm{V}+\mathrm{Ni})$ in Niger Delta oil, place the Niger Delta source rocks in Lewan's (1984) Regime II with respect to source-rock depositional conditions. These trace-metal data, together with the organic geochemistry and physical properties of the oil indicate that the Niger Delta source rocks contain

\footnotetext{
${ }^{4}$ Oils derived from marine organic matter of mid-Cretaceous or younger age have ratios between 0.05 and 0.2 (Paul Lillis, U.S. Geological Survey, personal communication).
} 
A. Oil fields
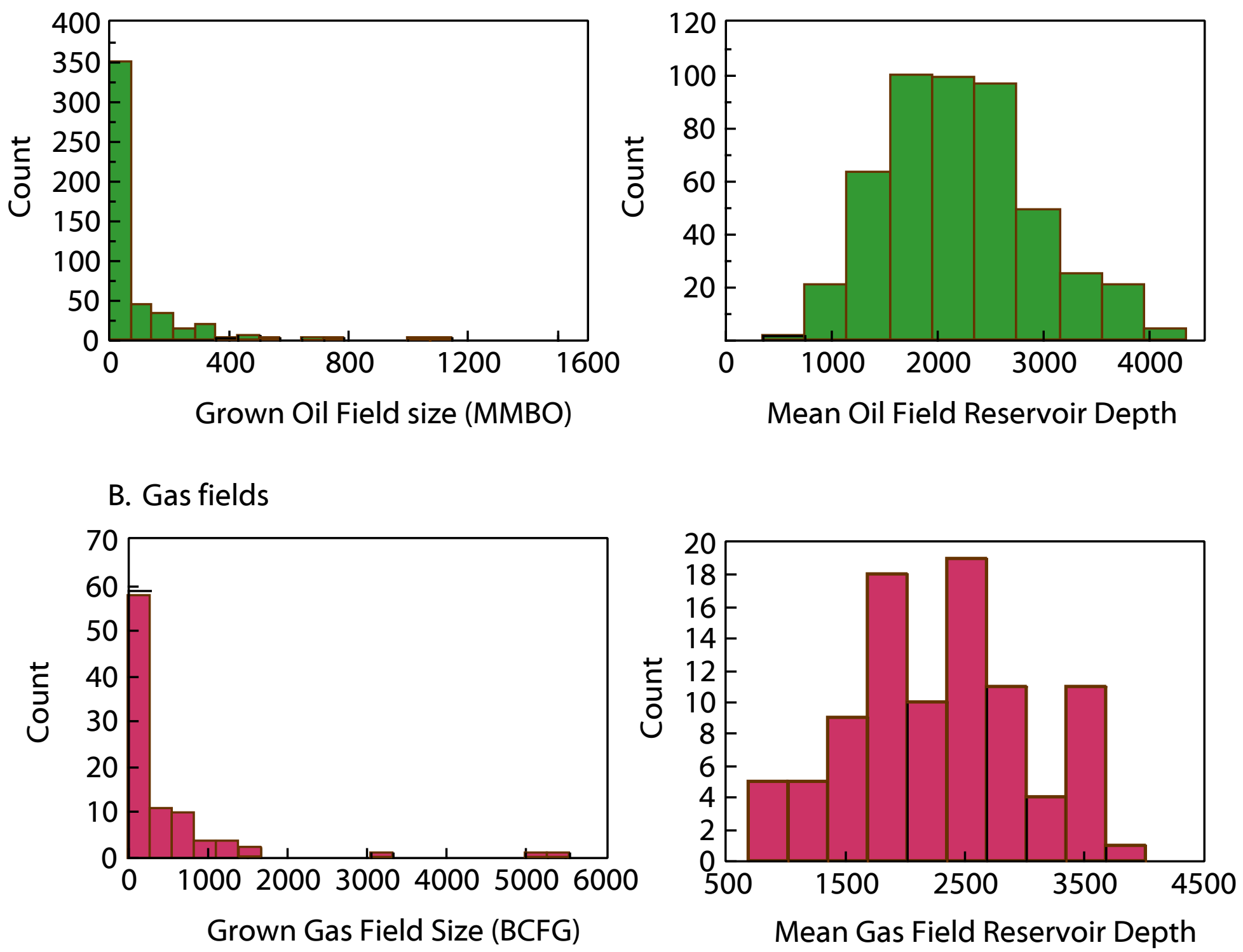

Figure 12. Histograms showing the distribution of size and average reservoir depth in (A) oil fields and (B) gas fields. Data from Petroconsultants (1996a). 


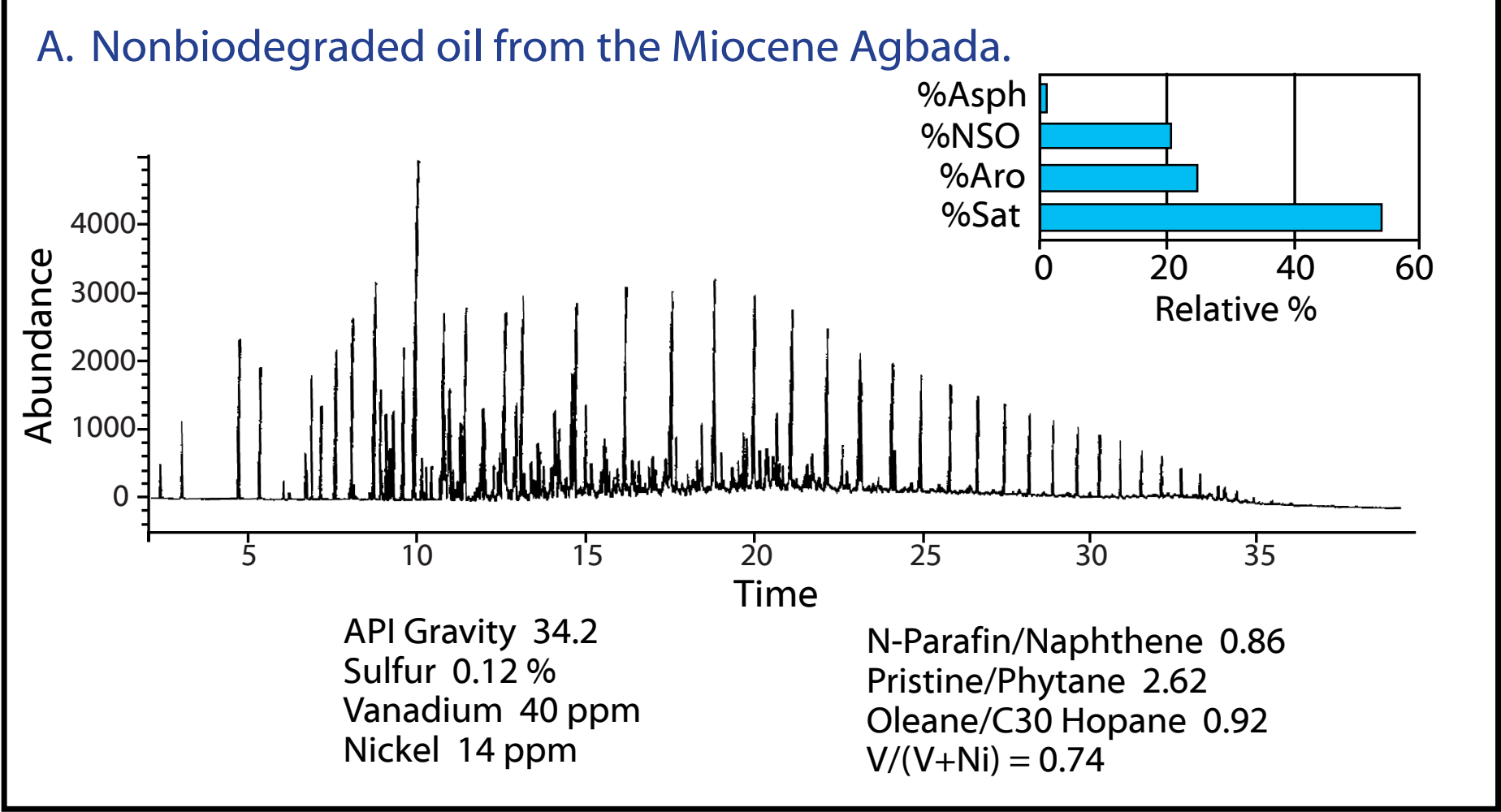

B. Biodegraded oil from the Miocene Agbada.

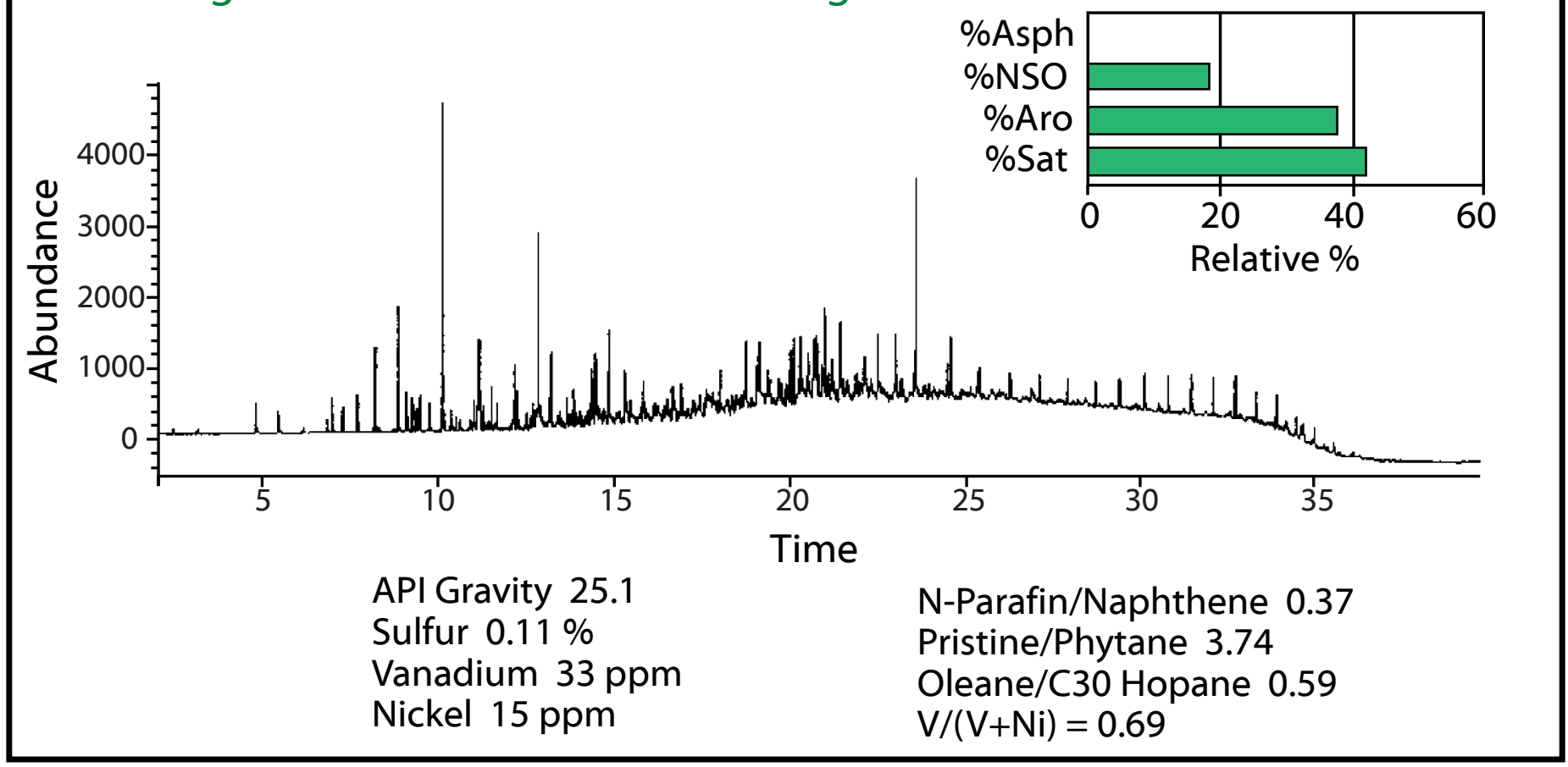

Figure 13. Geochemical data for a nonbiodegraded oil (A) and a partially biodegraded oil (B) from the Niger Delta. Data include whole crude gas chromatograms, chart showing relative proportions of bulk composition and a variety of physical and chemical analyses and ratios. Data from Geomark Research, Inc. (1998). 
predominately terrestrial organic matter. The organic matter was deposited in suboxic-anoxic bottom waters where vanadyl and nickel availability for bonding was hindered in part by formation of hydroxides and complexing with metastable sulfide ions, respectively. Preservation of the organic matter would be quite good under these conditions.

The associated gas in the Niger Delta is thermal in origin $\left(\delta^{13} \mathrm{C}\right.$ values of -36 to $40 \%$; Doust and Omatsola, 1990), with low $\mathrm{CO}_{2}$ and $\mathrm{N}_{2}$ concentrations. Hydrogen sulfide is not a problem associated with Niger Delta gas; however, relatively high mercury concentrations have been observed. Currently, $75 \%$ of the gas produced from the Niger Delta is flared, ${ }^{5} 10 \%$ is reinjected to maintain reservoir pressure, and only 15\% marketed. (Energy Information Administration, 1998b).

\section{SOURCE ROCK}

\section{Source Rock Identification}

There has been much discussion about the source rock for petroleum in the Niger Delta (e.g. Evamy and others, 1978; Ekweozor and others, 1979;

Ekweozor and Okoye, 1980; Lambert-Aikhionbare and Ibe, 1984; Bustin, 1988; Doust and Omatsola, 1990). Possibilities include variable contributions from the marine interbedded shale in the Agbada Formation and the marine Akata shale, and a Cretaceous shale (Weber and Daukoru, 1975; Evamy and others, 1978; Ejedawe and others, 1979; Ekweozor and Okoye, 1980; Ekweozor and Daukoru, 1984; Lambert-Aikhionbare and Ibe, 1984; Doust and Omatsola, 1990; Stacher, 1995; Frost, 1977; Haack and others, 1997).

Agbada-Akata. The Agbada Formation has intervals that contain organiccarbon contents sufficient to be considered good source rocks (see data in Ekweozor and Okoye, 1980; Nwachukwu and Chukwura, 1986). The intervals, however, rarely reach thickness sufficient to produce a world-class oil province and are immature in various parts of the delta (Evamy and others, 1978; Stacher, 1995). The Akata shale is present in large volumes beneath the Agbada Formation (fig. 8A) and is at least volumetrically sufficient to generate enough oil for a world class oil province such as the Niger Delta.

Based on organic-matter content and type, Evamy and others (1978) proposed that both the marine shale (Akata Fm.) and the shale interbedded with paralic sandstone (lower Agbada Fm.) were the source rocks for the Niger Delta oils.

\footnotetext{
${ }^{5}$ Currently, an effort is underway to recover much of the associated gas for piping to near-by West Africa countries.
} 
Ekweozor and others (1979) used $\alpha \beta$-hopanes and oleananes to fingerprint crude with respect to their source--the shale of the paralic Agbada Formation on the eastern side of the delta and the Akata marine-paralic source on the western side of the delta. Ekweozor and Okoye (1980) further constrained this hypothesis using geochemical maturity indicators, including vitrinite reflectance data, that showed rocks younger than the deeply buried lower parts of the paralic sequence to be immature. Lambert-Aikhionbare and Ibe (1984) argued that the migration efficiency from the over-pressured Akata shale would be less than $12 \%$, indicating that little fluid would have been released from the formation. They derived a different thermal maturity profile, showing that the shale within the Agbada Formation is mature enough to generate hydrocarbons. [See discussion about expulsion from abnormally pressured source rocks in the section on Petroleum Generation, Migration and Accumulation.]

Ejedawe and others (1984) use maturation models to conclude that in the central part of the delta, the Agbada shale sources the oil while the Akata shale sources the gas. In other parts of the delta, they believe that both shales source the oil. Doust and Omatsola (1990) conclude that the source organic matter is in the deltaic offlap sequences and in the sediments of the lower coastal plain. Their hypothesis implies that both the Agbada and Akata Formations likely have disseminated source rock levels, but the bulk will be in the Agbada Formation. In deep water, they favor delta slope and deep turbidite fans of the Akata Formation as source rocks. The organic matter in these environments still maintains a terrestrial signature, however, it may be enriched in amorphous, hydrogen-rich matter from bacterial degradation. Stacher (1995) proposes that the Akata Formation is the only source rock volumetrically significant and whose depth of burial is consistent with the depth of the oil window.

Cretaceous. Some have proposed that marine Cretaceous shale beneath the Niger Delta is a viable source rock (e.g. pre-Albian super source rock; Frost, 1997). This Cretaceous section has never been drilled beneath the delta due to its great depth; therefore, no data exist on its source-rock potential. Migration of oil from the Cretaceous into the reservoirs in the Agbada Formation would have required an intricate fault/fracture network as the Akata shale reaches a thickness greater than 6,000 meters. No data exist to support such a network. The chemical composition of the oils provides conflicting evidence for the hypothesis of a Cretaceous source rock, especially for an Early Cretaceous one. Nwachukwu and others (1995) report low V:V+Ni ratios in Niger Delta crude (0.12), a ratio quite smaller than the ratio in Cretaceous oils in onshore seeps in the northern portion of the province (0.46; Oluwole and others, 1985 as cited in Kulke, 1995). The $\mathrm{V}+\mathrm{Ni}$ ratios for Miocene oils reported in 1998 by 
Geomark Research Inc. (fig. 13), however, are similar to those in the Cretaceous oils. Significant oleanane is found in Niger Delta crude. This compound is related to angiosperms, which only became wide spread in the Late Cretaceous-Tertiary. Haack and others (1997) use the northern Gulf of Mexico Basin model of older rocks sourcing oils in deeper water to suggest that oil in hypothetical deep-water plays of the Niger Delta may be sourced, in part, by Upper Cretaceous rocks. As these oils are in hypothetical plays, no geochemical data are available yet to test such a hypothesis in the Niger Delta.

\section{Source Rock Chemical Characteristics}

Bustin (1988), in a detailed source-rock study on side-wall core and cuttings from the Agbada-Akata transition or uppermost Akata Formation, concluded that there are no rich source rocks in the delta. With respect to oil potential, Bustin claims that the poor source-rock quality has been more than compensated by their great volume, excellent migration pathways, and excellent drainage. The oil potential is further enhanced by permeable interbedded sandstone and rapid hydrocarbon generation resulting from high sedimentation rates. The total organic-carbon (TOC) content of sandstone, siltstone, and shale in his study is essentially the same (average of 1.4 to $1.6 \%$ TOC). The content, however, seems to vary with age of the strata-a trend of decreasing content with decreasing age (average of $2.2 \%$ in the late Eocene compared to $0.9 \%$ in Pliocene strata). Bustin's Eocene TOC average compares well with the averages of $2.5 \%$ and $2.3 \%$ obtained for Agbada-Akata shales in two wells (Udo and Ekweozor, 1988). Ekeweozor and Okoye (1980) report TOC values from 0.4 to $14.4 \%$ in the both onshore and offshore paralic sediments. Nwachukwu and Chukwura (1986) report values as high as $5.2 \%$ in paralic shales from the western part of the delta. The higher TOC contents are limited to thin beds and are only easily recognized in conventional cores (Doust and Omatsola, 1990).

The organic matter consists of mixed maceral components (85-98\% vitrinite with some liptinites and amorphous organic matter) (Bustin, 1988). There is no evidence of algal matter and the shales are low in sulfur (.02 to .1\%). Hydrogen indices (HI) are quite low and generally range from 160 to less than $50 \mathrm{mg} \mathrm{HC} / \mathrm{g}$ TOC. Ekweozor and Daukoru (1994) believe that Bustin's average of $90 \mathrm{mg} \mathrm{HC} / \mathrm{g}$ TOC underestimates the true source-rock potential because of matrix effects on whole-rock pyrolysis of deltaic rocks. Udo and others (1988) report $\mathrm{HI}$ values of 232 for immature kerogen isolates from Agbada-Akata shales. HI values over 400 have been measured (U.S. Geological Survey, unpublished proprietary data).

Pristane/phytane in extracts range between 2 and 4 (Bustin, 1988). Bustin found that both HI values and pristane/phytane change with stratigraphic position similarly to TOC contents (lower values in younger strata). He 
attributes these stratigraphic trends in organic-matter to increased dilution as sedimentation rates increased and possibly an increase in oxidizing conditions of the depositional environment.

\section{Source Rock Potential}

Demaison and Huizinga (1994) have estimated the average source potential index (SPI) for the Niger Delta at $14 \mathrm{t} \mathrm{HC} / \mathrm{m}^{2}$. Given that the Niger Delta is a vertically drained system (drainage area small), the SPI value is in the upper portion of the medium range of worldwide values. SPI is calculated as follows:

SPI (in metric tons $\left.\mathrm{HC} / \mathrm{m}^{2}\right)=\mathrm{h}\left(\mathrm{S}_{1}+\mathrm{S}_{2}\right) \rho / 1000$ where $h$ is thickness of source rock in meters, $S_{1}+S_{2}$ is the average genetic potential in kilograms of HC per metric ton of rock, and $\rho$ is the rock density in metric tons per cubic meter (Demaison and Huizinga, 1994). Using a genetic potential of $7.5 \mathrm{~kg} / \mathrm{t}$ (median of U.S. Geological Survey unpublished proprietary Niger Delta data) and assuming a density of $2.26 \mathrm{~g} / \mathrm{cm}^{3}$ (Michael Lewan, U.S. Geological Survey, written communication, 1999), the thickness of source rocks required by the above equation is 825 meters. This is much larger than the 100 to 300 meter thickness calculated using material balance equations (Michael Lewan, U.S. Geological Survey, written communication, 1999) as summarized in Chapter B. One hundred to 300 meters of mature source rock could be easily accommodated in the mature, lower portion of the Agbada Formation and the uppermost Akata Formation.

We agree with researchers (Evamy and others, 1978 among others) who believe that both formations are source rocks for the Niger Delta oil. The two formations are just different facies within the same depositional system and likely contain similar organic matter. Each formation contributes variably to the hydrocarbons generated, depending on the location within the delta and the depth of burial. Based on proposed migration pathways, oil composition, and a variety of other factors, we tend to favor a source-rock thickness on the order of 100 to 300 meters rather than 825 meters. A 100 to 300 meter thickness implies that, if correct, the SPI value for the Niger Delta estimated by Demaison and Huizinga (1994) is too high.

\section{RESERVOIR ROCK}

Petroleum in the Niger Delta is produced from sandstone and unconsolidated sands predominantly in the Agbada Formation. Characteristics of the reservoirs in the Agbada Formation are controlled by depositional environment and by depth of burial. Known reservoir rocks are Eocene to Pliocene in age, and are often stacked, ranging in thickness from less than 15 meters to $10 \%$ having greater than 45 meters thickness (Evamy and others, 
1978). The thicker reservoirs likely represent composite bodies of stacked channels (Doust and Omatsola, 1990). Based on reservoir geometry and quality, Kulke (1995) describes the most important reservoir types as point bars of distributary channels and coastal barrier bars intermittently cut by sand-filled channels. Edwards and Santogrossi (1990) describe the primary Niger Delta reservoirs as Miocene paralic sandstones with $40 \%$ porosity, 2 darcys permeability, and a thickness of 100 meters. The lateral variation in reservoir thickness is strongly controlled by growth faults; the reservoir thickens towards the fault within the down-thrown block (Weber and Daukoru, 1975). The grain size of the reservoir sandstone is highly variable with fluvial sandstones tending to be coarser than their delta front counterparts; point bars fine upward, and barrier bars tend to have the best grain sorting. Much of this sandstone is nearly unconsolidated, some with a minor component of argillo-silicic cement (Kulke, 1995). Porosity only slowly decreases with depth because of the young age of the sediment and the coolness of the delta complex (see geothermal gradient data below).

In the outer portion of the delta complex, deep-sea channel sands, low-stand sand bodies, and proximal turbidites create potential reservoirs (Beka and Oti, 1995). Burke (1972) describes three deep-water fans that have likely been active through much of the delta's history (fig. 14). The fans are smaller than those associated with other large deltas because much of the sand of the Niger-Benue system is deposited on top of the delta, and buried along with the proximal parts of the fans as the position of the successive depobelts moves seaward (Burke, 1972). The distribution, thickness, shaliness, and porosity/permeability characteristics of these fans are poorly understood (Kulke, 1995).

Tectono-stratigraphy computer experiments ${ }^{6}$ show that local fault movement along the slope edge controls thickness and lithofacies of potential reservoir sands downdip (Smith-Rouch and others, 1996). The slope-edge fault simulation from these experiments is shown in Figure 15. Smith-Rouch (written communication, 1998) states that "by extrapolating the results to other areas along the shelf margin, new potential reservoirs are identified."

\footnotetext{
6 "Four experiments in tectono-stratigraphy were conducted on a digitized offshore Nigeria seismic profile using a 2-D forward stratigraphic computer simulation (PHIL). One set of experiments evaluated diverse stratigraphic responses to variable accommodation space developed first via eustasy, second via fault movement and third via a combination of eustasy and variable fault movement. The best match between simulation horizon thickness and stratal geometry and seismic horizons was developed by fluctuating the rate of fault movement in partner with a well constrained regional sea level curve ," (Linda Smith-Rouch, U.S. Geological Survey, written communication, 1998).
} 


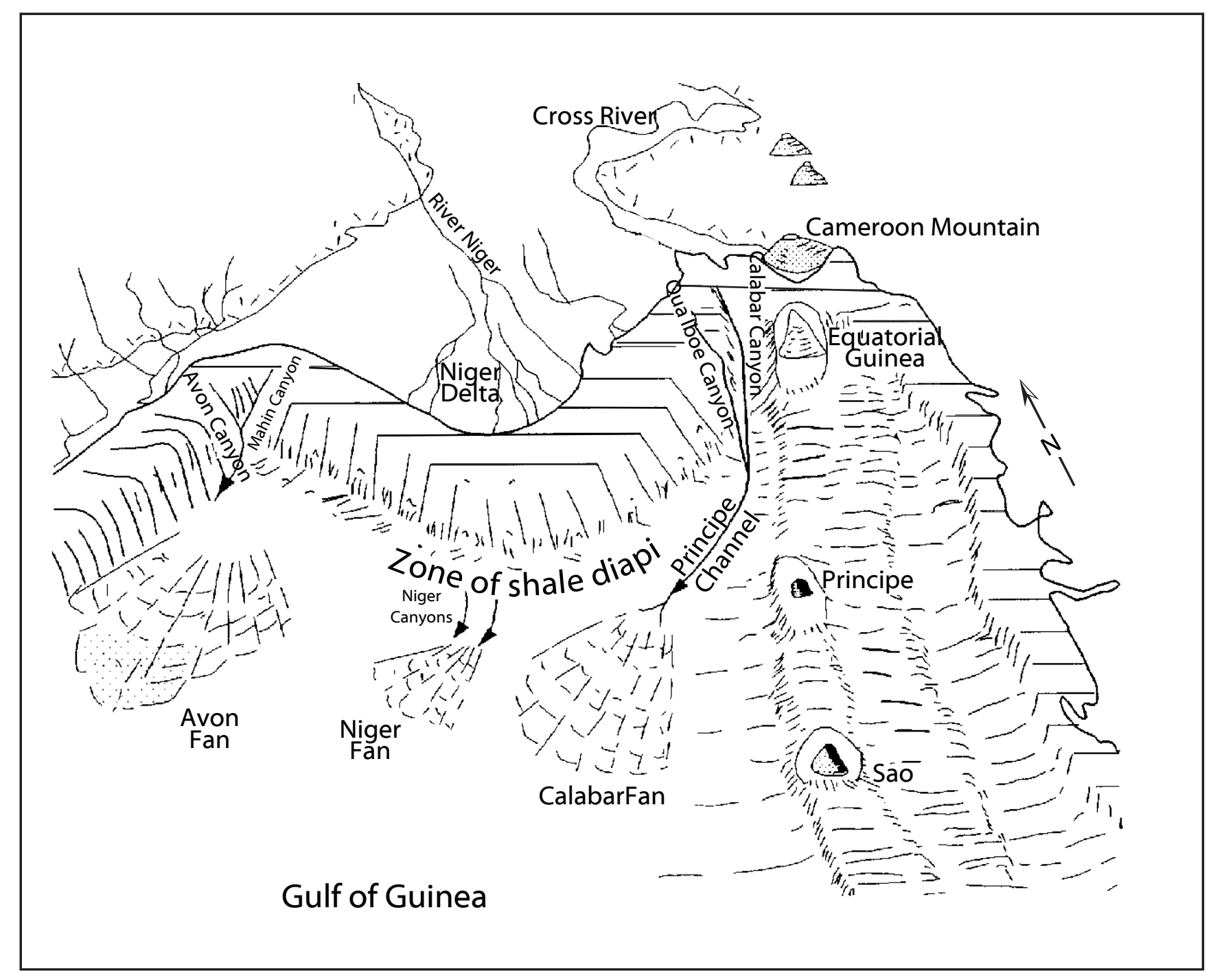

Figure 14. Physiographic sketch of the deep marine sediments in the Gulf of Guinea off the Niger Delta. Modified from Burke (1972) and Reijers and others (1997). 


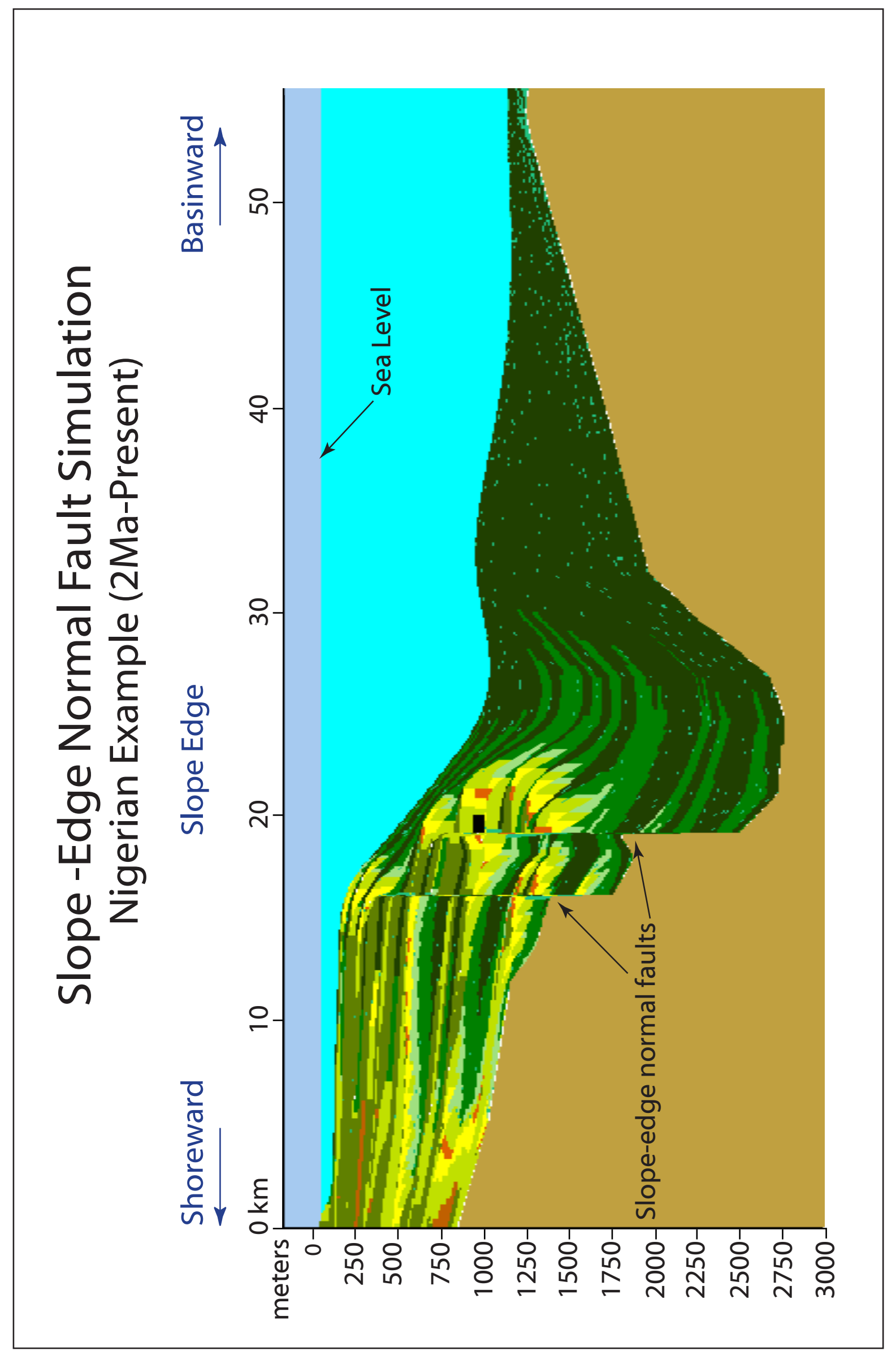

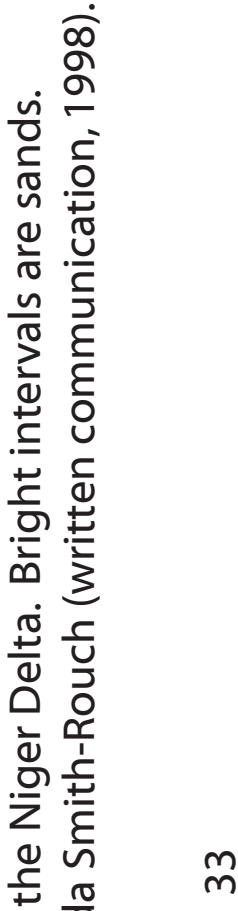
후음 흔 응 잉 흐응 交

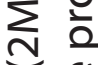
으 음 풍 으 כ ह ำ 음 壱 $\frac{0}{\frac{0}{0}}$ $\stackrel{\frac{0}{x}}{\frac{0}{x}}$ है ㅎํㄴ 工 ปั 잉 잉 응 운 ज 음 เก 논 言品 


\section{TRAPS AND SEALS}

Most known traps in Niger Delta fields are structural although stratigraphic traps are not uncommon (fig. 16). The structural traps developed during synsedimentary deformation of the Agbada paralic sequence (Evamy and others, 1978; Stacher, 1995). As discussed earlier, structural complexity increases from the north (earlier formed depobelts) to the south (later formed depobelts) in response to increasing instability of the under-compacted, overpressured shale. Doust and Omatsola (1990) describe a variety of structural trapping elements, including those associated with simple rollover structures, clay filled channels, structures with multiple growth faults, structures with antithetic faults, and collapsed crest structures.

On the flanks of the delta, stratigraphic traps are likely as important as structural traps (Beka and Oti, 1995). In this region, pockets of sandstone occur between diapiric structures. Towards the delta toe (base of distal slope), this alternating sequence of sandstone and shale gradually grades to essentially sandstone.

The primary seal rock in the Niger Delta is the interbedded shale within the Agbada Formation. The shale provides three types of seals-clay smears along faults, interbedded sealing units against which reservoir sands are juxtaposed due to faulting, and vertical seals (Doust and Omatsola, 1990). On the flanks of the delta, major erosional events of early to middle Miocene age formed canyons that are now clay-filled (fig. 7). These clays form the top seals for some important offshore fields (Doust and Omatsola, 1990).

\section{PETROLEUM GENERATION AND MIGRATION}

Evamy and others (1978) set the top of the present-day oil window in the Niger Delta at the $240^{\circ} \mathrm{F}\left(115^{\circ} \mathrm{C}\right)$ isotherm. In the northwestern portion of the delta, the oil window (active source-rock interval) lies in the upper Akata Formation and the lower Agbada Formation as shown in Figure 17. To the southeast, the top of the oil window is stratigraphically lower (up to 4000' below the upper Akata/lower Agbada sequence; Evamy and others, 1978). Some researchers (Nwachukwu and Chukwura, 1986; Doust and Omatsola, 1990; Stacher, 1995) attribute the distribution of the top of the oil window to the thickness and sand/shale ratios of the overburden rock (Benin Fm. and variable proportions of the Agbada Fm.). The sandy continental sediment (Benin Fm.) has the lowest thermal gradient $\left(1.3\right.$ to $\left.1 / 8^{\circ} \mathrm{C} / 100 \mathrm{~m}\right)$; the paralic Agbada Formation has an intermediate gradient $\left(2.7^{\circ} \mathrm{C} / 100 \mathrm{~m}\right)$; and the marine, over-pressured Akata Formation has the highest $\left(5.5^{\circ} \mathrm{C} / 100 \mathrm{~m}\right)$ (Ejedawe and others, 1984). Therefore, within any depobelt, the depth to any temperature is dependent on the gross distribution of sand and shale. If 


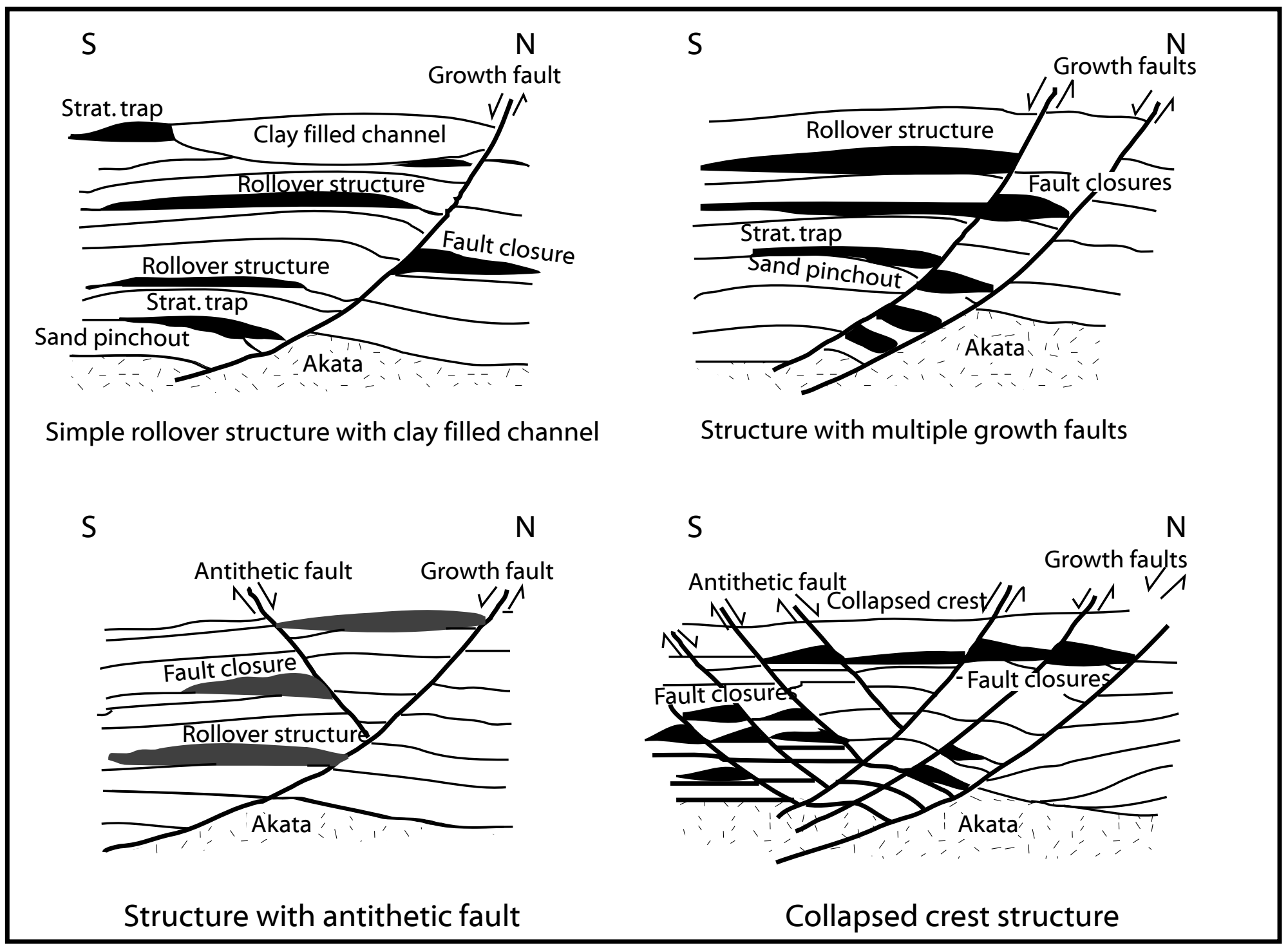

Figure 16. Examples of Niger Delta oil field structures and associated trap types. Modified from Doust and Omatsola (1990) and Stacher (1995). 


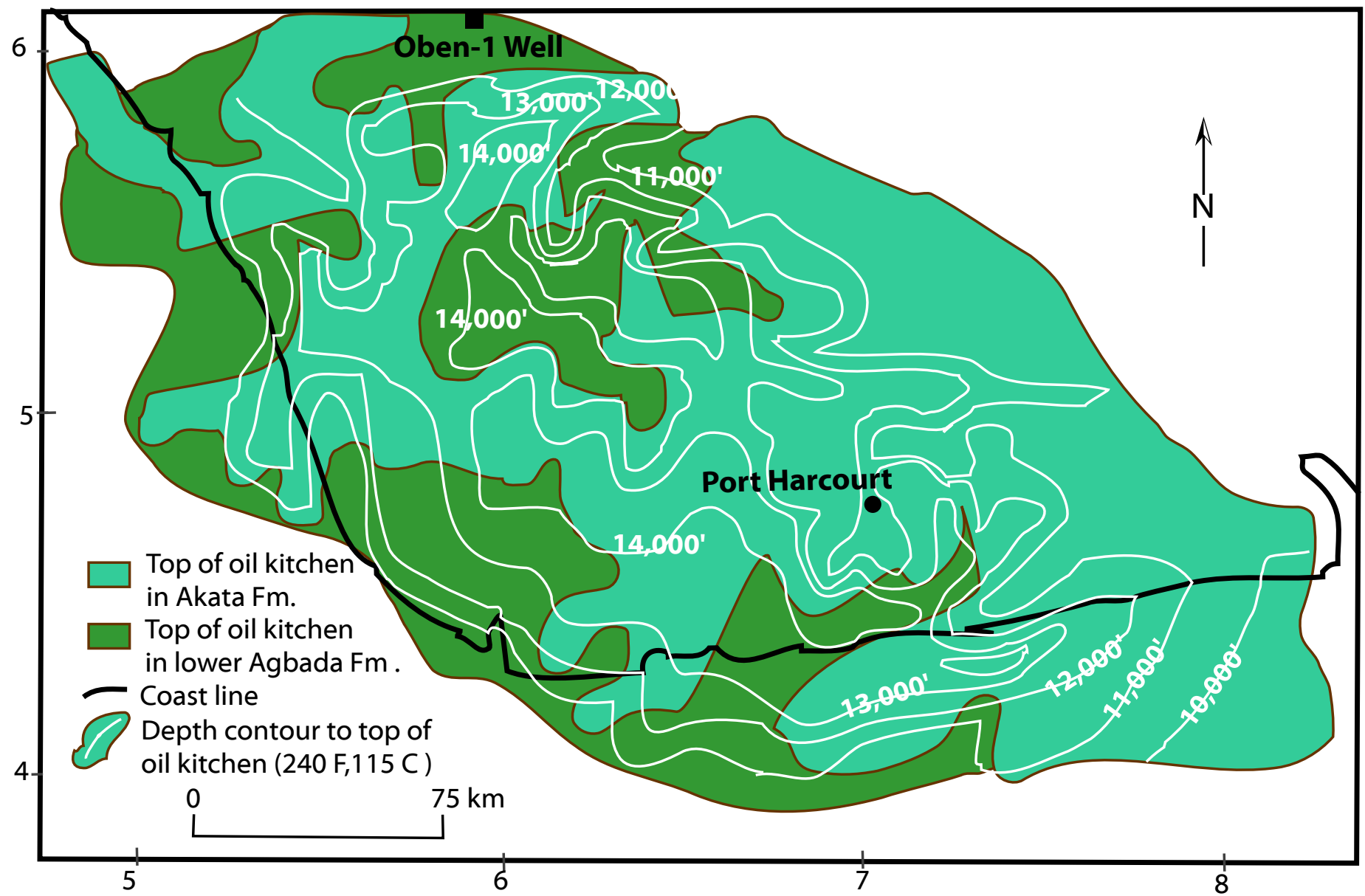

Figure 17. Subsurface depth to top of Niger Delta oil kitchen showing where only the Akata Formation is in the oil window and where a portion of the lower Agbada is in the oil window. Contours are in feet. Modified from Evamy and others (1978). 
sand/shale ratios were the only variable, the distal offshore subsurface temperatures would be elevated because sand percentages are lower. To the contrary, the depth of the hydrocarbon kitchen is expected to be deeper than in the delta proper, because the depth of oil generation is a combination of factors (temperature, time, and deformation related to tectonic effects) (Beka and Oti, 1995).

Figure 18 shows a burial history chart for the Oben-1 well in the northern portion of the delta (see fig. 17 for well location). In the late Eocene, the Akata/Agbada formational boundary in the vicinity of this well entered the oil window at approximately $0.6 \mathrm{R}_{\mathrm{o}}$ (Stacher, 1995). Evamy and other (1978) argue that generation and migration processes occurred sequentially in each depobelt and only after the entire belt was structurally deformed, implying that deformation in the Northern Belt would have been completed in the Late Eocene. ${ }^{7}$ The Akata/Agbada formational boundary in this region is currently at a depth of about 4,300 m, with the upper Akata Formation in the wet gas/condensation generating zone (vitrinite reflectance value $>1.2$; Tissot and Welte, 1984). The lowermost part of the Agbada Formation here entered the oil window sometime in the Late Oligocene.

The Northern Belt's Ajalomi- 1 well about $25 \mathrm{~km}$ to the south of Oben-1 shows the Akata source rock first entering the oil window in the Oligocene after reservoir rock deposition (see Figure 14, p. 266 in Stacher, 1995). Stacher assumes migration overlaps in time with the burial and structure development of overlying reservoir sequences and occurs primarily across and up faults (see fig. 11). Migration pathways were short as evidenced from the wax content, API gravity, and the chemistry of oils (Short and Stäuble, 1967; Reed, 1969).

Migration from mature, over-pressured shales in the more distal portion of the delta may be similar to that described from over-pressured shales in the Gulf of Mexico. Hunt (1990) relates episodic expulsion of petroleum from abnormally pressured, mature source rocks to fracturing and resealing of the top seal of the over-pressured interval. In rapidly sinking basins, such as the Gulf of Mexico, the fracturing/resealing cycle occurs in intervals of thousands of years. This type cyclic expulsion is certainly plausible in the Niger Delta basin where the Akata Formation is over-pressured. Beta and Oti (1995) predict a bias towards lighter hydrocarbons (gas and condensate) from the over-pressured shale as a result of down-slope dilution of organic matter as well as differentiation associated with expulsion from over-pressured sources.

\footnotetext{
${ }^{7}$ The distribution of biodegraded oils with depth (no biodegradation below $82^{\circ} \mathrm{C}$ ) strongly suggests that migration of the oil was late and that subsidence did not occur after migration (for a discussion of this argument, see Evamy and others, 1978; Doust and Omatsola, 1989).
} 


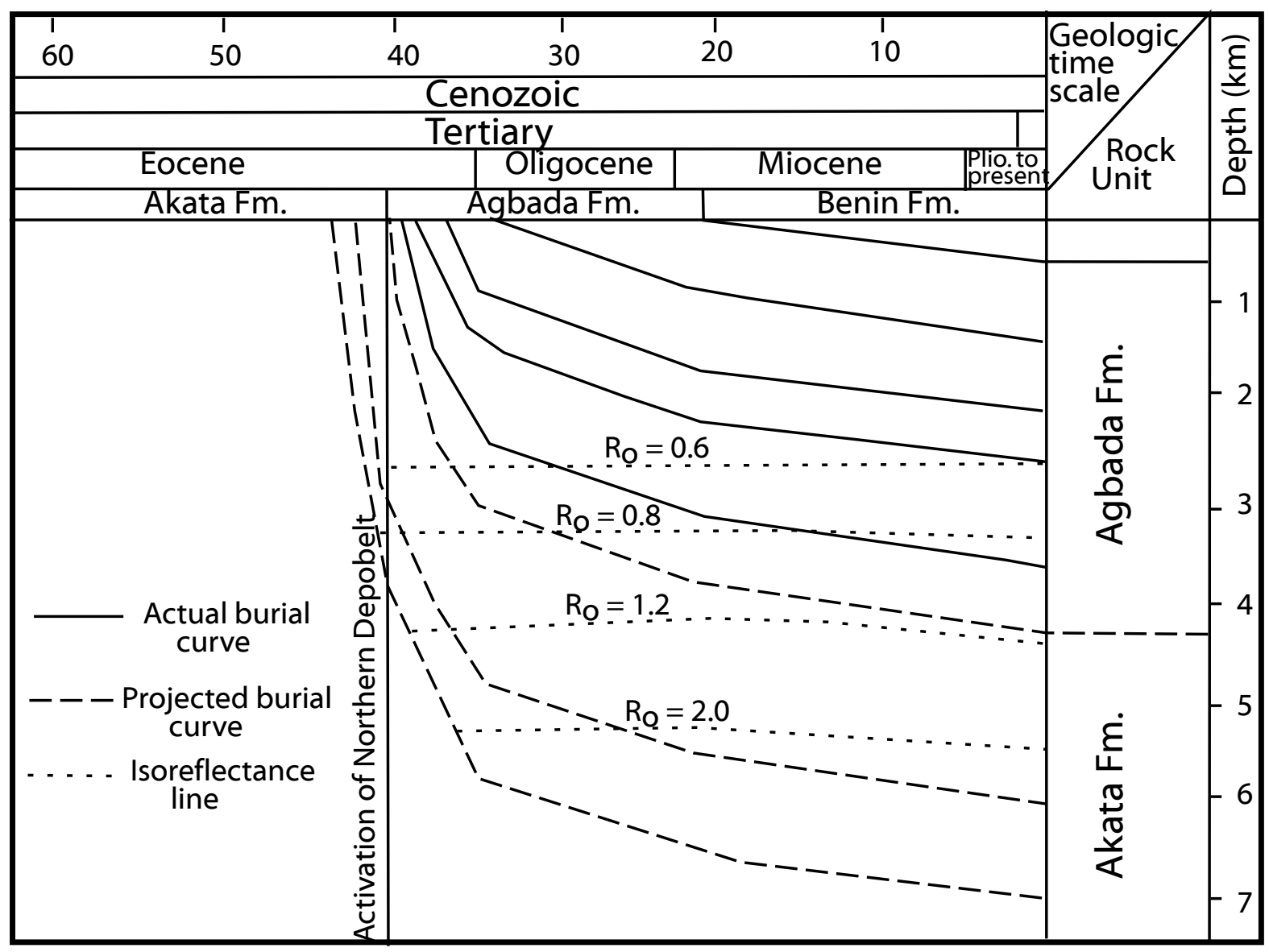

Figure 18. Burial history chart for the northern portion of the Niger Delta (Akata/Agbada) petroleum system. Data from Oben-1 well in Northern Depobelt (see fig. 17 for location). Modified from Ekweozor and Daukoru (1994). 


\section{SUMMARY}

The history of the formation of the Tertiary Niger Delta (Akata-Agbada) petroleum system is summarized in the events chart (fig. 19). Rocks within the petroleum system are from Paleocene to Recent in age. Most of the petroleum is sourced from the Akata Formation, with smaller amounts generated from the mature shale beds in the lower Agbada Formation. Deposition of overburden rock began in the Middle Eocene and continues to the present. Units include the Agbada and Benin Formations to the north with a transition to the Akata Formation in the deep-water portion of the basin where the Agbada and Benin Formations thin and disappear seaward.

Petroleum generation within the delta began in the Eocene and continues today. Generation occurred from north to south as progressively younger depobelts entered the oil window. Reservoirs for the discovered petroleum are sandstones throughout the Agbada Formation. Reservoirs for undiscovered petroleum below currently producing intervals and in the distal portions of the delta system may include turbidite sands within the Akata. Trap and seal formation is related to gravity tectonics within the delta. Structural traps have been the most favorable exploration target, however, stratigraphic traps are likely to become more important targets in distal and deeper portions of the delta. 


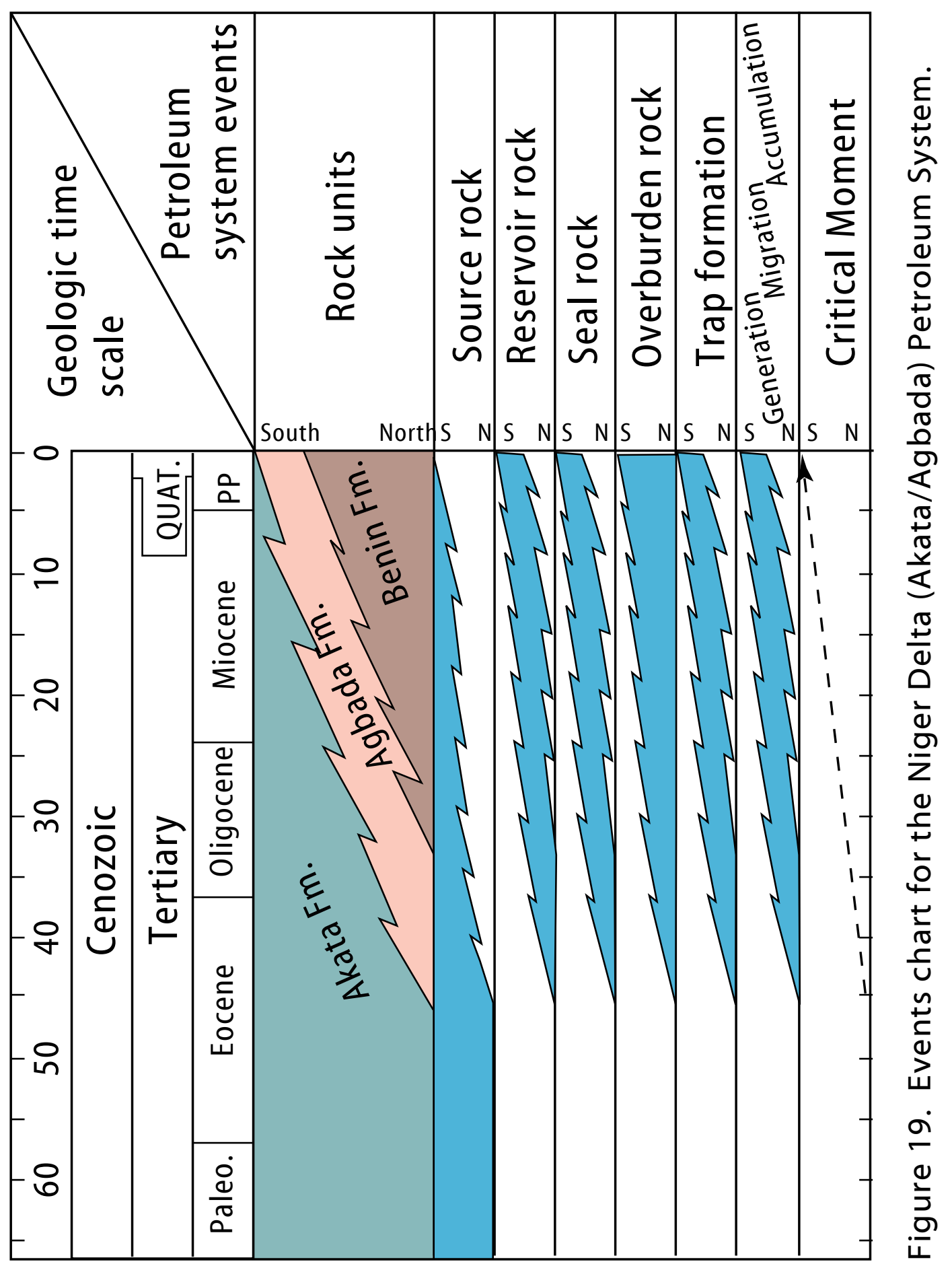




\section{REFERENCES CITED IN CHAPTER A}

Avbovbo, A. A., 1978, Tertiary lithostratigraphy of Niger Delta: American Association of Petroleum Geologists Bulletin, v. 62, p. 295-300.

Beka, F. T., and Oti, M. N., 1995, The distal offshore Niger Delta: frontier prospects of a mature petroleum province, in, Oti, M.N., and Postma, G., eds., Geology of Deltas: Rotterdam, A.A. Balkema, p. 237-241.

Burke, K., 1972, Longshore drift, submarine canyons, and submarine fans in development of Niger Delta: American Association of Petroleum Geologists, v. 56, p. 1975-1983.

Bustin, R. M., 1988, Sedimentology and characteristics of dispersed organic matter in Tertiary Niger Delta: origin of source rocks in a deltaic environment: American Association of Petroleum Geologists Bulletin, v. 72, p. 277-298.

Demaison, G., and Huizinga, B.J., 1994, Genetic classification of petroleum systems using three factors: charge, migration, and entrapment, in, Magoon, L.B., and Dow, W.G., eds., The Petroleum System--From Source to Trap, AAPG Memoir 60: Tulsa, American Association of Petroleum Geologists, p. 73-89.

Doust, H., and Omatsola, E., 1990, Niger Delta, in, Edwards, J. D., and Santogrossi, P.A., eds., Divergent/passive Margin Basins, AAPG Memoir 48: Tulsa, American Association of Petroleum Geologists, p. 239-248.

Edwards, J.D., and Santogrossi, P.A., 1990, Summary and conclusions, in, Edwards, J.D., and Santogrossi, P.A., eds., Divergent/passive Margin Basins, AAPG Memoir 48: Tulsa, American Association of Petroleum Geologists, P. 239-248.

Ejedawe, J.E., 1981, Patterns of incidence of oil reserves in Niger Delta Basin: American Association of Petroleum Geologists, v. 65, p. 1574-1585.

Ejedawe, J.E., Coker, S.J.L., Lambert-Aikhionbare, D.O., Alofe, K.B., and Adoh, F.O., 1984, Evolution of oil-generative window and oil and gas occurrence in Tertiary Niger Delta Basin: American Association of Petroleum Geologists, v. 68, p. 1744-1751.

Ekweozor, C. M., and Daukoru, E.M, 1984, Petroleum source bed evaluation of Tertiary Niger Delta--reply: American Association of Petroleum Geologists Bulletin, v. 68, p. 390-394.

Ekweozor, C. M., and Daukoru, E.M, 1994, Northern delta depobelt portion of the Akata-Agbada(!) petroleum system, Niger Delta, Nigeria, in, Magoon, L.B., and Dow, W.G., eds., The Petroleum System--From Source to Trap, AAPG Memoir 60: Tulsa, American Association of Petroleum Geologists, p. 599-614. 
Ekweozor, C. M., Okogun, J.I., Ekong, D.E.U., and Maxwell J.R., 1979, Preliminary organic geochemical studies of samples from the Niger Delta, Nigeria: Part 1, analysis of crude oils for triterpanes: Chemical Geology, v 27, p. 11-28.

Ekweozor, C.M., and Okoye, N.V., 1980, Petroleum source-bed evaluation of Tertiary Niger Delta: American Association of Petroleum Geologists Bulletin, v. 64, p 1251-1259.

Energy Information Administration, 1998a, <http://www.eia.doe.gov/emeu/ cabs/ngriasar.html>

Energy Information Administration, 1998b, <http://www.eia.doe.gov/emeu/ world/country / cntry_NI.html>

Evamy, B.D., Haremboure, J., Kamerling, P., Knaap, W.A., Molloy, F.A., and Rowlands, P.H., 1978, Hydrocarbon habitat of Tertiary Niger Delta: American Association of Petroleum Geologists Bulletin, v. 62, p. 277298.

Frost, B.R. ,1997, A Cretaceous Niger Delta Petroleum System, in, Extended Abstracts, AAPG/ABGP Hedberg Research Symposium, Petroleum Systems of the South Atlantic Margin, November 16-19, 1997, Rio de Janeiro, Brazil.

GeoMark Research, Inc., 1998, OILS: Oil Information Library System, version 1.0: Houston, Texas, GeoMark Research, Inc., [database available from GeoMark Research, Inc., 9748 Whithorn Drive, Houston, TX 77095].

Haack, R.C., Sundararaman, P., and Dahl, J., 1997, Niger Delta petroleum System, in, Extended Abstracts, AAPG/ABGP Hedberg Research Symposium, Petroleum Systems of the South Atlantic Margin, November 16-19, 1997, Rio de Janeiro, Brazil.

Hospers, J., 1965, Gravity field and structure of the Niger Delta, Nigeria, West Africa: Geological Society of American Bulletin, v. 76, p. 407-422.

Hunt, J.M., 1990, Generation and migration of petroleum from abnormally pressured fluid compartments: American Association of Petroleum Geologists Bulletin, v. 74, p. 1-12.

Kaplan, A., Lusser, C.U., Norton, I.O., 1994, Tectonic map of the world, panel 10: Tulsa, American Association of Petroleum Geologists, scale $1: 10,000,000$.

Klett, T.R., Ahlbrandt, T.S., Schmoker, J.W., and Dolton, J.L., 1997, Ranking of the world's oil and gas provinces by known petroleum volumes: U.S. Geological Survey Open-file Report-97-463, CD-ROM.

Kulke, H., 1995, Nigeria, in, Kulke, H., ed., Regional Petroleum Geology of the World. Part II: Africa, America, Australia and Antarctica: Berlin, Gebrüder Borntraeger, p. 143-172.

Lambert-Aikhionbare, D. O., and Ibe, A.C., 1984, Petroleum source-bed evaluation of the Tertiary Niger Delta: discussion: American Association of Petroleum Geologists Bulletin, v. 68, p. 387-394. 
Lehner, P., and De Ruiter, P.A.C., 1977, Structural history of Atlantic Margin of Africa: American Association of Petroleum Geologists Bulletin, v. 61, p. 961-981.

Lewan M.D., 1984, Factors controlling the proportionality of vanadium to nickel in the bitumen of organic sedimentary rocks: Geochimica et Cosmochimica Acta, v. 48, p. 2231-2238

Lewan, M.D., and Maynard, J.B., 1982, Factors controlling enrichment of vanadium and nickel in the bitumen of organic sedimentary rocks: Geochimica et Cosmochimica Acta, v. 46, p. 2547-2560.

Magoon, L.B., and Dow, W.G., 1994, the petroleum System, in, Magoon, L.B., and Dow, W.G., eds., The Petroleum System--from Source to trap, AAPG Memoir 60: Tulsa, American Association of Petroleum Geologists, p. 3-24.

Mbendi, 1996, <http:/ / mbendi.co.za/cyngoi.html>

Nwachukwu, S.O., 1972, The tectonic evolution of the southern portion of the Benue Trough, Nigeria: Geology Magazine, v. 109, p. 411-419.

Nwachukwu,J.I., and Chukwurah, P. I., 1986, Organic matter of Agbada Formation, Niger Delta, Nigeria: American Association of Petroleum Geologists Bulletin, v. 70, p. 48-55.

Nwachkwu, J.I., Oluwole, A.F., Asubiojo, O.I., Filby, R.H., Grimm, C.A., and Fitzgerald, S., 1995, A geochemical evaluation of Niger Delta crude oils, in, Oti, M.N., and Postma, G., eds., Geology of Deltas: Rotterdam, A.A. Balkema, p. 287-300.

Oluwole, A.F., Adegoke, O.S., Kehinde, L.O. et al., 1985, Chemical composition of bitumen extracts from Nigerian tar sands, in, 3rd. International UNITAR/UNDP Heavy Crude \& Tar Sand conf., Long Beach, CA, USA, 22.--31.7.85, Preprints 1, 467-480.

Persits, F., Ahlbrandt, T., Tuttle, M., Charpentier, R., and Brownfield, M., 1997, Map of the geology, oil and gas field, and geologic provinces of Africa, U.S. Geological Survey Open-file Report 97-470A, CD-ROM.

Petroconsultants, 1996a, Petroleum exploration and production database: Houston, Texas, Petroconsultants, Inc., [database available from Petroconsultants, Inc., P.O. Box 740619, Houston, TX 77274-0619].

Petroconsultants, 1996b, PetroWorld 21: Houston, Texas, Petroconsultants, Inc., [database available from Petroconsultants, Inc., P.O. Box 740619, Houston, TX 77274-0619].

Reed, K.J., 1969, Environment of deposition of source beds of high-wax oil: American Association of Petroleum Geologists Bulletin, v. 53, p. 15021506.

Reijers, T.J.A., Petters, S.W., and Nwajide, C.S., 1997, The Niger Delta Basin, in Selley, R.C., ed., African Basins--Sedimentary Basin of the World 3: Amsterdam, Elsevier Science, pp. 151-172.

Shannon, P. M., and Naylor N., 1989, Petroleum Basin Studies: London, Graham and Trotman Limited, p 153-169. 
Short, K. C., and Stäublee, A.J., 1965, Outline of geology of Niger Delta: American Association of Petroleum Geologists Bulletin, v. 51, p. 761779.

Smith-Rouch, L. S., Meisling, K.E., Hennings, P.E., and Armentrout, J.M., 1996, Tectono-stratigraphic computer experiments-Nigeria example: American Association of Petroleum Geologists Bulletin Abstracts, May 1996.

Stacher, P., 1995, Present understanding of the Niger Delta hydrocarbon habitat, in, Oti, M.N., and Postma, G., eds., Geology of Deltas:

Rotterdam, A.A. Balkema, p. 257-267.

Thomas, 1995, Niger delta oil production, reserves, field sizes assessed: Oil \& Gas Journal, November 13, 1995, p. 101-103.

Tissot, B.P., and Welte, D.H., 1984, Petroleum Formation and Occurrence: Berlin, Springer-Verlag, p. 518.

UNESCO, 1990, International Geologic Map of Africa. Paris, CGMW and UNESCO, scale 1:5,000,000.

Udo, O.T., and Ekweozor C.M., 1988, Comparative source rock evaluation of Opuama Channel Complex and adjacent producing areas of Niger delta: Nigerian Association of Petroleum Explorationists Bulletin, 3, n. 2, p. 10-27.

Udo, O.T., Ekweozor, C.M., and Okogun, J.I., 1988, Petroleum geochemistry of an ancient clay-filled canyon in the western Niger delta, Nigeria: Nigerian Association of Petroleum Explorationists Bulletin, v. 3, p. 825.

Weber, K.J., 1987, Hydrocarbon distribution patterns in Nigerian growth fault structures controlled by structural style and stratigraphy: Journal of Petroleum Science and Engineering, v. 1, p. 91-104.

Weber, K. J., and Daukoru, E.M., 1975, Petroleum geology of the Niger Delta: Proceedings of the Ninth World Petroleum Congress, volume 2, Geology: London, Applied Science Publishers, Ltd., p. 210-221.

Whiteman, A., 1982, Nigeria: Its Petroleum Geology, Resources and Potential: London, Graham and Trotman, 394 p.

Xiao, H., and Suppe, J., 1992, Origin of rollover: American Association of Petroleum Geologists Bulletin, v. 76, p. 509-229. 


\title{
Chapter B
}

\section{Assessment of Undiscovered Petroleum in the Tertiary Niger Delta (Akata-Agbada) Petroleum System (No. 719201), Niger Delta Province, Nigeria, Cameroon, and Equatorial Guinea, Africa}

\author{
by Michele L. W. Tuttle, Ronald R. Charpentier, and Michael E. \\ Brownfield
}

\begin{abstract}
We estimate undiscovered resources of the Tertiary Niger Delta (Akata-Agbada) Petroleum System to be 40.5 billion barrels of oil and 133 trillion cubic feet of gas. These resources are distributed between two assessment units, the Agbada Deltaic Reservoir Unit and the Akata Turbidite Reservoir Unit. Material balance calculations estimate that between 100 and 300 meters thickness of source rock is needed to generate the known and undiscovered oil resources within the petroleum system.
\end{abstract}

\section{INTRODUCTION}

The Tertiary Niger Delta (Akata-Agbada) Petroleum System (referred to as Niger Delta Petroleum System hereafter) was assessed as part of the World Energy Project of the Energy Resources Program of the U.S. Geological Survey. The quantities of oil, gas, and natural gas liquids that have the potential to be added to reserves within the next 30 years were considered. These volumes either reside in undiscovered fields whose sizes exceed the minimum-field-size cutoff value (1 million barrels of oil equivalent in this petroleum system), or occur as reserve growth of oil and gas fields already discovered (field growth).

Our assessment methodology for estimating the numbers and sizes of undiscovered fields (Charpentier and Klett, in prep) is sensitive to the homogeneity of each population being assessed. Therefore, the Niger Delta Petroleum System was divided into two assessment units-the Agbada "Deltaic" Reservoir Assessment Unit (hereafter referred to as Agbada Unit) and the Akata "Turbidite" Reservoir Assessment Unit (hereafter referred to as Akata Unit). This division was made based on the fact that the number and size distribution of hypothetical fields in the Akata Formation will be significantly different than in the Agbada Formation. 


\section{AGBADA ASSESSMENT UNIT}

The boundaries of the Agbada Unit are shown on Figure 1. They are the province boundaries to the north, west, and east (for description of province boundaries see Chapter A) and the 200-meter bathymetric contour to the south. The area of the assessment unit is $103,000 \mathrm{~km}^{2}$. Reservoirs in this unit are primarily paralic sandstone related to the delta proper.

As a check on the Monte Carlo results, we evaluated the petroleum yield of the Niger Delta assuming an accumulation sediment thickness of $3.0 \mathrm{~km}$ (most oil reservoirs occur between 1,000 and 4,000 $\mathrm{m}$ depth, fig. 2, Chapter A). The sediment volume defined by discovered fields is about $300,000 \mathrm{~km}^{3}$. To date, the known volume of recoverable oil in both oil and gas fields is $34.5 \mathrm{BBO}$ (calculated from data in Petroconsultants, 1996). Our calculated oil yield is $115,000 \mathrm{bbls} / \mathrm{km}^{3}$ of sediment. The yield increases to $165,000 \mathrm{BOE} / \mathrm{km}^{3}$ when 93.8 TCFG gas is included. These yields are two to three times the maximum recovery of 53,700 BOE $/ \mathrm{km}^{3}$ given for delta systems in 1975 (based on Niger and Mississippi delta data; Klemme, 1975). In the last two decades, the recovery of the Niger Delta has increased dramatically over Klemme's estimate. This increase is probably due not only to new discoveries, but to field growth as well.

\section{Field Growth}

The assessment for the undiscovered petroleum in the Agbada uses data from Petroconsultants (1996) to estimate size and volume of undiscovered fields. As of 1995, 481 oil fields greater than $1 \mathrm{MMBO}$ and 93 gas fields greater than 6 BCFG were established in the Agbada Unit. The volume data were "grown" ${ }^{1}$ for 30 years to account for the observation that estimates of recoverable quantities in fields increase over time. A summary of the grown data for the Agbada Unit is in the table below.

\begin{tabular}{|l|c|}
\hline & 1995 Data Grown for 30 Years \\
\hline Oil in oil fields (BBO) & 43.9 \\
\hline Oil in gas fields (BBO) & 0.43 \\
\hline Gas in gas fields (TCFG) & 42.0 \\
\hline Gas in oil fields (TCFG) & 75.0 \\
\hline Total oil (BBO) & 44.3 \\
\hline Total gas (TCFG) & 117 \\
\hline Total NGL (BBNGL) & 3.4 \\
\hline Total volume (BBOE) & 66.3 \\
\hline
\end{tabular}

\section{Exploration for Undiscovered Petroleum}

We evaluated the exploration maturity of the assessment unit using a variety of indicators such as field density and plots of past discovery data. A total of 574

\footnotetext{
${ }^{1}$ Field growth factors derived by the U.S. Minerals Management Service for offshore fields were used to grow the fields for the next 30 years (Schmoker and Crovelli, 1998).
} 
fields (481 oil and 93 gas fields) at least as large as one million BOE are reported by Petroconsultants (1996), resulting in an average field density of one field in every $210 \mathrm{~km}^{2}$. Attanasi and Root (1993) calculated their "current" growth in delineated prospective area per wildcat well for Nigeria at $39 \mathrm{~km}^{2} /$ well. Attanasi and Root's value represents that area added to the "delineated prospective area" by each wildcat well drilled. Although the area:well ratio is relatively small, growth has remained relatively constant since the late 1960's, indicating that there has been a constant increment in prospective area with each wildcat well drilled. Although the growth in delineated prospective area per wildcat well will have to decrease sometime in the future, it is not possible to determine exactly when the decrease will begin.

Next, we evaluated the discovery history of the basin (field size and petroleum volumes). Analysis of oil exploration trends (fig. 2) show that a consistent high rate of number of fields discovered per unit exploration effort has been maintained but that the oil fields are smaller in size (figs. 3 and 4). This decrease is reflected in the overall decrease in the slope of the curve in Figure 3 and by comparing the median size of the first third of the fields discovered (60 MMB) to the second third discovered (22 MMB) to the third third discovered (23 MMB) (fig. 4). This analysis shows that although as many fields are being discovered as in the past, the discovery sizes have been smaller during the last two-thirds of the discovery history.

A similar analysis for gas fields (figs. 2, 3, and 5) shows exploration of gas fields is less mature than of oil fields. The curves generated by plotting cumulative oil fields versus cumulative number of new-field wildcat wells indicate that, per exploration unit, the number of oil fields being found in 1995 is not significantly different than that in 1952. In addition, the size of the gas fields is not systematically decreasing with exploration-a median size of 116 BCFG for the first third discovered, 58 BCFG for the second third, and 119 BCFG for the third third (fig. 5). We might expect that gas discoveries may be more prevalent in the future, especially with development of liquefied natural gas export facilities (Thomas, 1995).

Future exploration targets for potential on-shore and off-shore undiscovered petroleum within the Agbada Unit include:

1. Structural traps similar to those explored in the past,

2. Stratigraphic traps, and

3. Faulted, low-stand sandstones on the slope edge. Continued exploration for the traditional structural traps onshore and near offshore is expected to yield some new fields, but the mature level of exploration will probably mean fewer and smaller discoveries of this type in the future.

\section{Assumptions for Assessing Undiscovered Petroleum}

The following four assumptions were made for assessing the undiscovered petroleum in the Agbada Unit. 


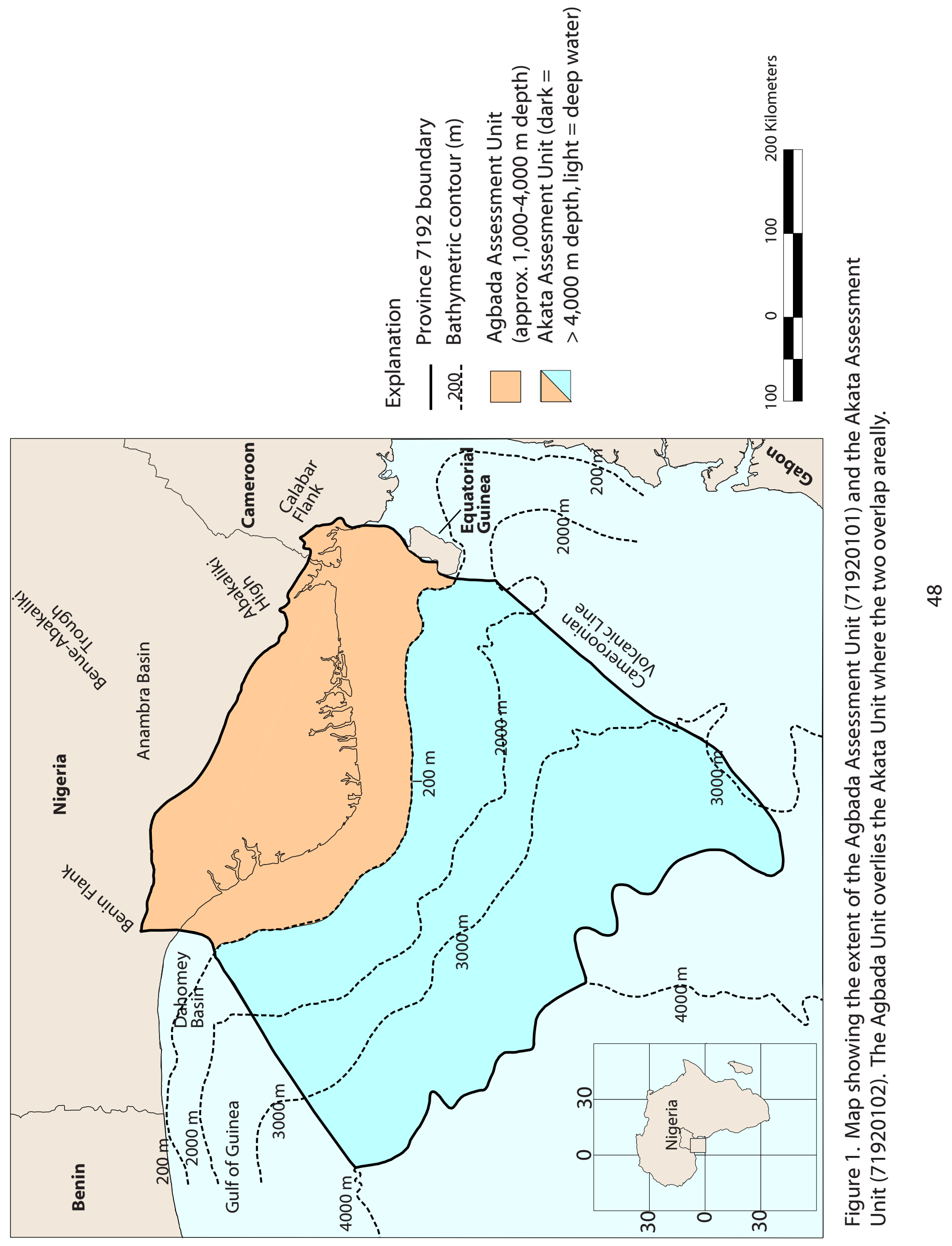



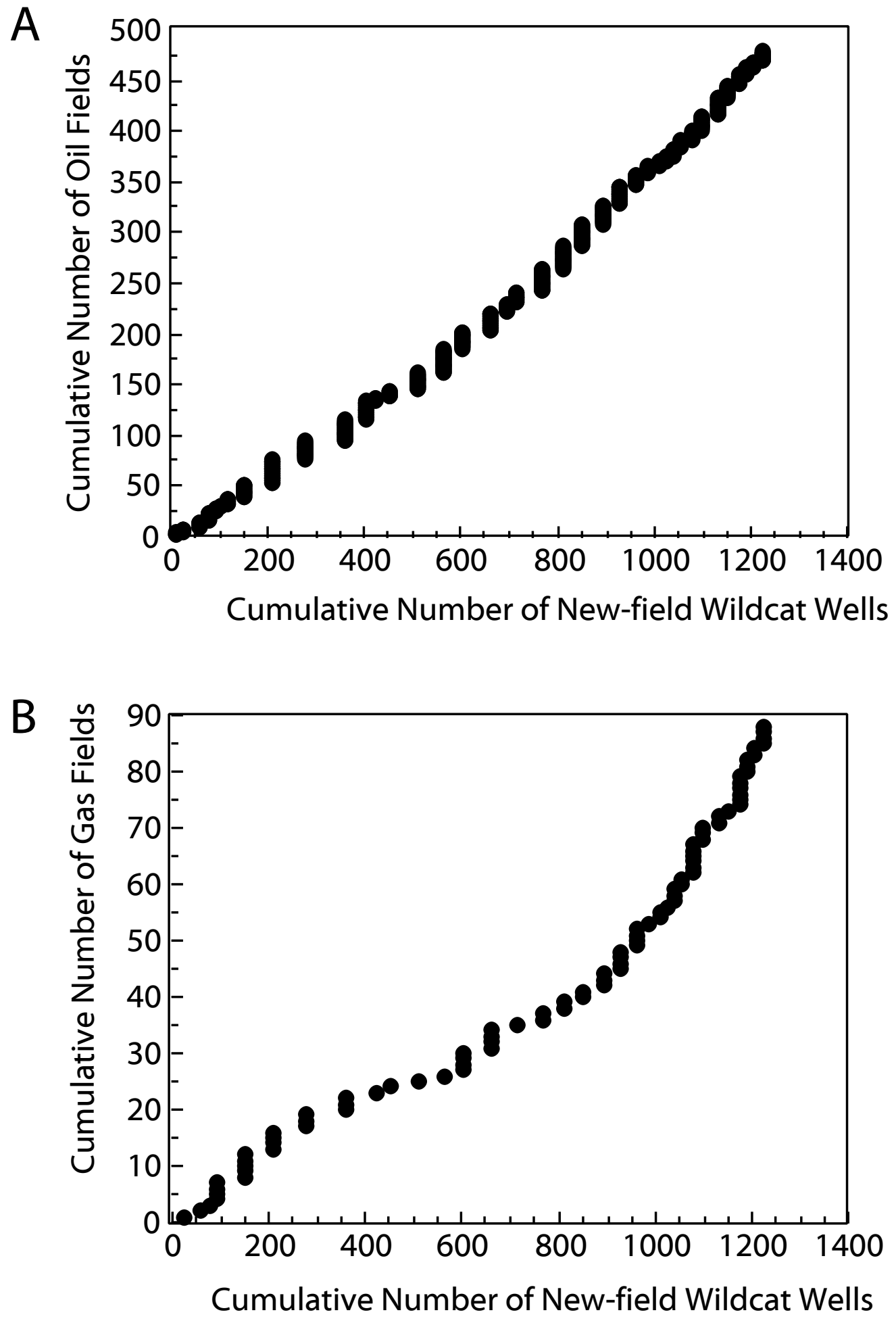

Figure 2. Crossplots for cumulative number of (A) oil fields and (B) gas fields versus cumulative number of total new-field wildcat wells in the Niger Delta Province. Data from Petroconsultants (1996). 

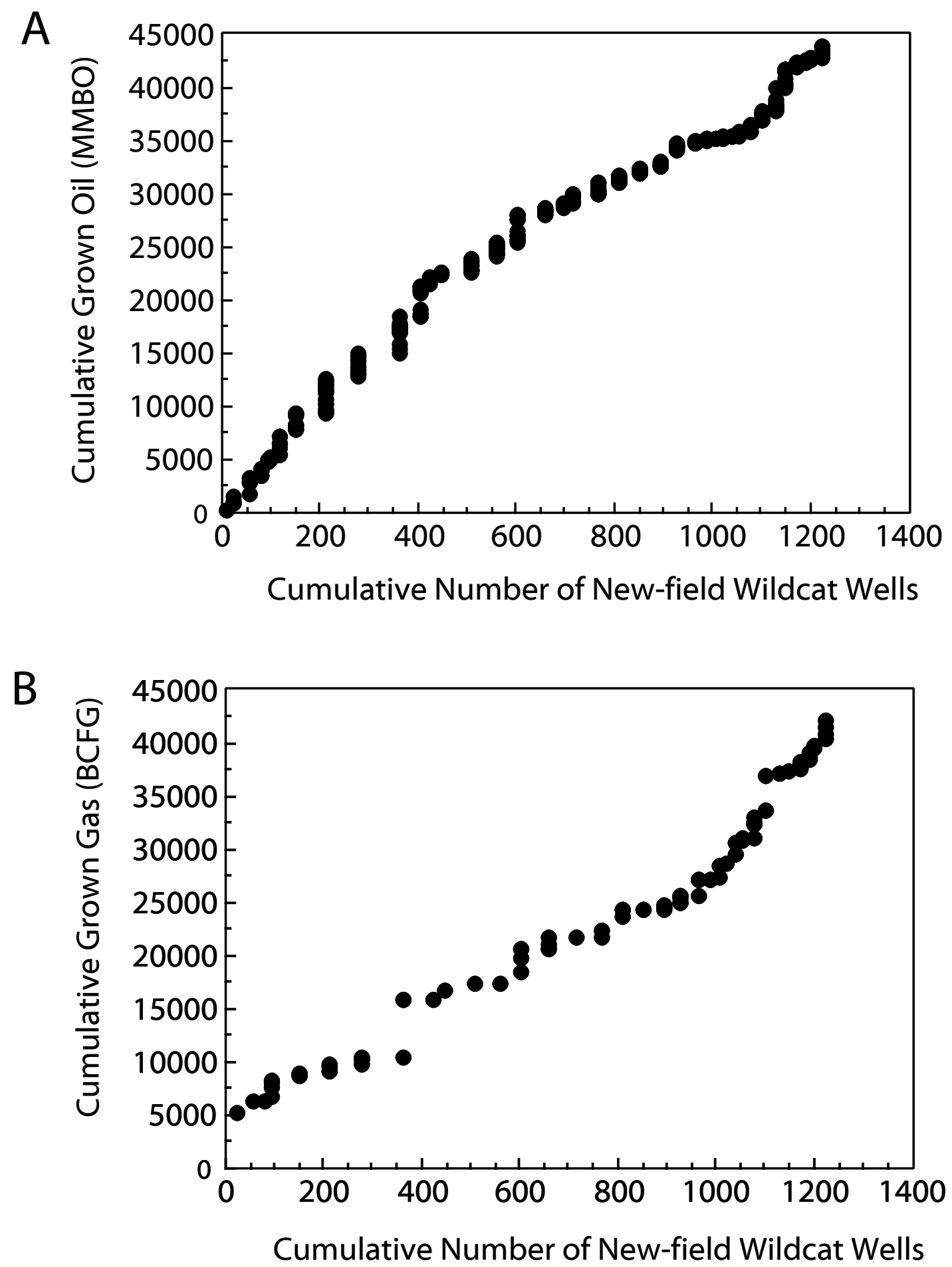

Figure 3. Crossplots for cumulative volume of discovered (A) grown oil fields (MMBO) and (B) grown gas fields (BCFG) versus cumulative number of new-field wildcat wells in the Niger Delta Province. Data from Petroconsultants (1996). 


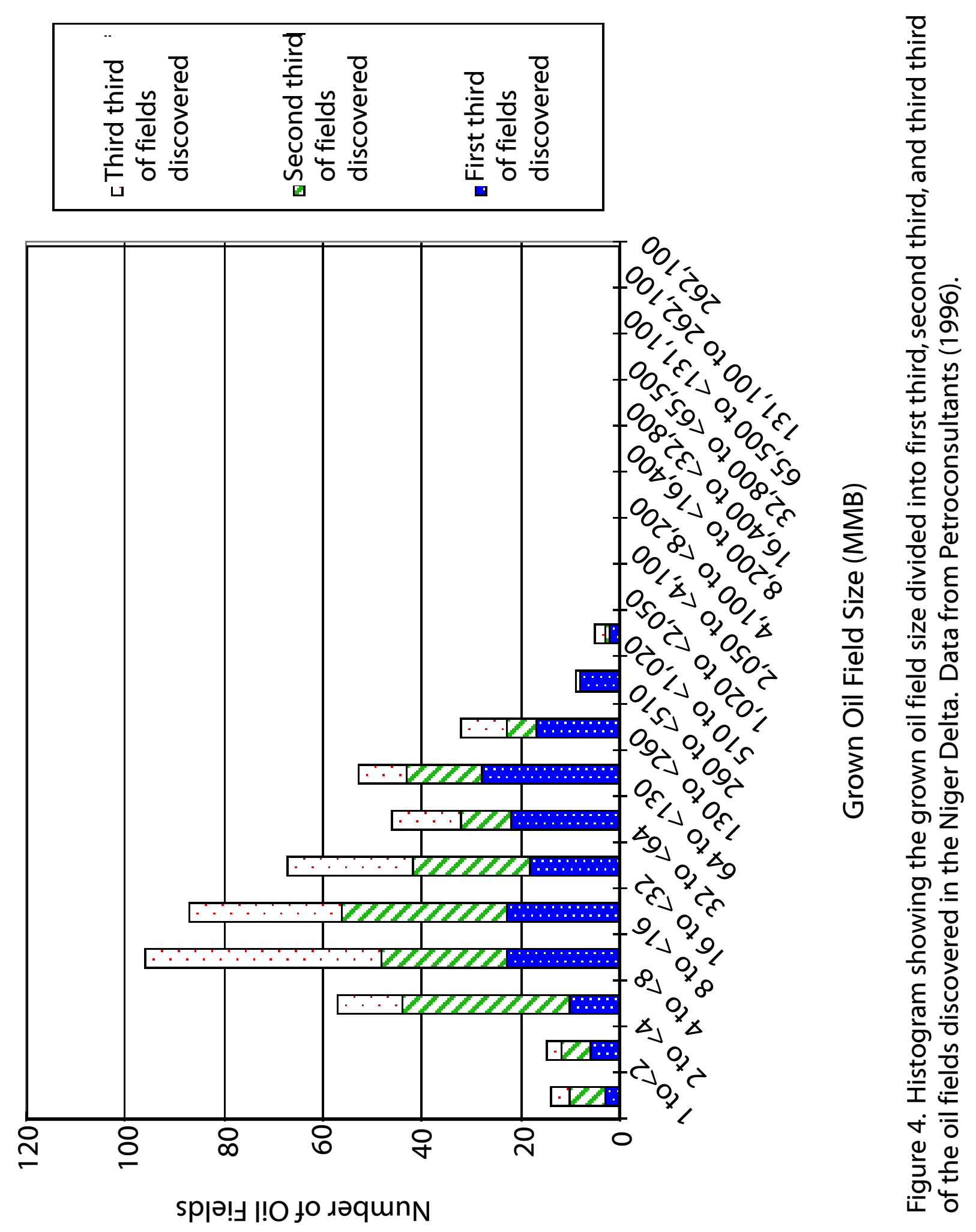




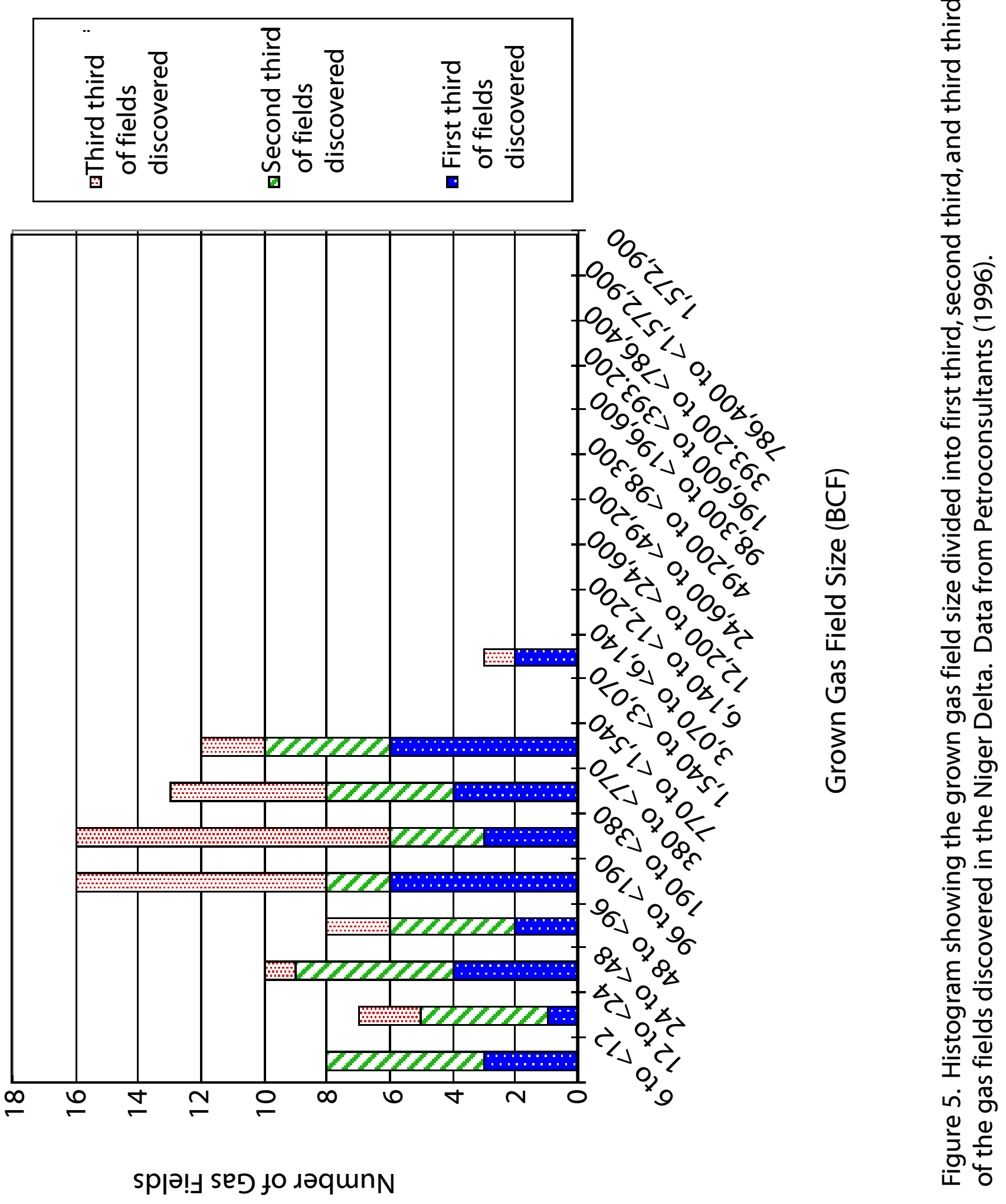

ก 
1. Major growth fault trends and structural trends within each depobelt are relatively evenly distributed across the assessment unit (Evamy and others, 1978, their Figure 10). Even though large, easily identified structures have been preferentially targeted, a few likely remain to be found based on the field sizes found recently (second largest oil field discovered in 1990 and the third largest gas field in 1989).

2. Undiscovered fields likely will include a greater percentage (and number) of smaller fields associated with stratigraphic traps that have been less attractive exploration targets in the past.

3. Undiscovered fields will have similar characteristics with respect to API, sulfur content, and producing depth. However, gas to oil ratios (GOR) in these fields probably will be greater than reported due to poor tracking of gas data to date. The natural gas liquids:gas ratio (NGL/gas) in undiscovered oil and gas fields likely is represented well by reported data.

4. The maturity of gas exploration is less than that of oil as gas has not been a significant exploration target in the past. This assumption is supported by the fact that $75 \%$ of gas produced in oil fields is currently flared.

Assessment of Undiscovered Petroleum in the Agbada Assessment Unit The following is the input for our assessment of undiscovered fields (see Appendix A):

\begin{tabular}{|l|c|c|c|}
\hline & Minimum & Median & Maximum \\
\hline No. of oil fields & 200 & 580 & 1,000 \\
\hline Size of oil fields (MMBO) & 1 & 12 & 1,500 \\
\hline No. of gas fields & 100 & 250 & 400 \\
\hline Size of gas fields (BCFG) & 6 & 60 & 7,000 \\
\hline
\end{tabular}

The estimates for the number and size of oil fields were derived as follows:

1. Minimum number of fields assumes that the stratigraphic traps within the assessment unit are not as numerous as we would expect, and the minimum field size is the cutoff for this petroleum system (1 MMBO).

2. Median number of fields reflects our conclusion that slightly less than one-half the oil fields have been discovered (based on exploration maturity analysis), and their median size is about one-half that for the second third and third third discovered fields.

3. Maximum number of fields assumes that the stratigraphic traps are far more common than we anticipated.

The estimates for number and size of gas fields were derived as follows:

1. Minimum number of fields assumes that the stratigraphic traps within the assessment unit are not as numerous as expected, and the minimum field size is the cutoff for this petroleum system (6 BCFG).

2. Median number of fields reflects our conclusion that about $1 / 3$ of the gas fields have been discovered, and median size is about one-half that for third third discovered fields. 
4. Maximum number of fields assumes that the stratigraphic traps are far better than we anticipated, and maximum volume allows for several large gas fields to be found.

The results from Monte Carlo simulations for the Agbada Assessment unit are in Appendix B and summarized in the table below.

\begin{tabular}{|l|c|c|}
\hline & Oil Fields & Gas Fields \\
\hline Mean volume of oil (BBO) & 21.9 & $--^{2}$ \\
\hline Mean volume of gas (TCFG) & 40.1 & 45.1 \\
\hline Mean volume of NGL (BBNGL) & 1.3 & 2.7 \\
\hline Largest Field (mean) & $1.0 \mathrm{BBO}$ & 3.8 TCFG \\
\hline
\end{tabular}

\section{AKATA ASSESSMENT UNIT}

The Akata Unit covers the entire Niger Delta Petroleum System, and is stratigraphically below the Agbada Unit where both formations exist (fig. 1). The area of the assessment unit is $300,000 \mathrm{~km}^{2}$-about equal size to the Mississippi Delta complex. About 56,000 $\mathrm{km}^{2}$ of the unit is on land and $244,000 \mathrm{~km}^{2}$ is in water. The Akata Assessment Unit is hypothetical and has no reported fields.

\section{Analogs for Hypothetical Fields}

Potential exists for significant discoveries in turbidite-related reservoirs in the Akata Formation. Reservoirs would be associated particularly with proximal turbidite "mounds," low-stand sands, and channel deposits. Marine shale of the Akata Formation serves as both source rock and seal. Exploration for turbiditerelated reservoirs in the Akata Formation will be in the deeper water offshore (turbidite reservoirs of the Campos basin, Brazil are currently being developed in waters >2,000 $\mathrm{m}$ in depth; Guardado and others, 1990). Onshore Akata reservoirs in the deeper stratigraphic sections underlying current production will be generally at depths greater than $2,500 \mathrm{~m}$ on the flanks of the delta to over $5,500 \mathrm{~m}$ in the center of the delta complex (see fig. $8 \mathrm{~A}$ in Chapter $\mathrm{A}$ ).

The Niger delta currently has three large submarine fan systems that have been active since the Eocene. We assume that, at least during the Oligocene and Miocene, these fans would have been extensive and perhaps each fan is similar to that deposited during the Oligocene in the Campos basin. Therefore, the PlioPleistocene channel fill and Oligocene sheets of sand in the Campos basin were used as an analogue for the number of fields in this assessment unit. We assigned three "sweet spots" to the assessment unit and assumed a much lower density for the remaining area in the assessment unit.

The oil field sizes in the Campos reservoirs were considered less useful than the number of fields because source rocks for the Niger Delta and the Campos are

\footnotetext{
${ }^{2}$ Included in the mean volume of NGL.
} 
very different (marine in the Niger Delta versus lacustrine in the Campos Basin). The charge assigned to the hypothetical reservoirs likely reflects this difference. Therefore, the Gulf Coast offshore data were used as the analog for the median size of fields in the Akata Unit.

\section{Assessment of Undiscovered Petroleum in the Akata Assessment Unit}

The following is the input for our assessment of undiscovered fields (see Appendix A):

\begin{tabular}{|l|c|c|c|}
\hline & Minimum & Median & Maximum \\
\hline No. of oil fields & 10 & 250 & 500 \\
\hline Size of oil fields (MMBO) & 1 & 23 & 3,000 \\
\hline No. of gas fields & 4 & 100 & 200 \\
\hline Size of gas fields (BCFG) & 6 & 60 & 3,500 \\
\hline
\end{tabular}

The estimates for number and size of oil and gas fields were derived as follows:

1. Minimum number of fields assumes the Campos reservoirs were a poor analog, and the minimum oil and gas volume is the cutoff for this petroleum system (1 MMBO; 6BCFG).

2. Median number of fields reflects our assumption that the Campos is a reasonable analog for the turbidite complexes, and median size reflects our assumption that the Gulf of Mexico offshore data are a good analog for oil and gas field sizes.

3. Maximum number of fields assumes that the reservoirs and traps are more numerous than we anticipated, maximum oil field size assumes that the Campos basin is an analog for oil field sizes as well as number of fields, and maximum gas field size allows for several gas fields $>3$ TCFG to be found.

The results from the Monte Carlo simulations for the Akata Assessment Unit are presented in Appendix B and summarized in the table below.

\begin{tabular}{|l|c|c|}
\hline & Oil Fields & Gas Fields \\
\hline Mean volume of oil (BBO) & 18.6 & $--^{3}$ \\
\hline Mean volume of gas (TCFG) & 34.0 & 13.6 \\
\hline Total volume (BBOE) & 25.1 & 3.1 \\
\hline Largest Field (mean) & $1.6 \mathrm{BBO}$ & $1.5 \mathrm{TCFG}$ \\
\hline
\end{tabular}

\section{MATERIAL BALANCE CALCULATIONS FOR PETROLEUM IN THE AGBADA ASSESSMENT UNIT}

Mass balance equations provided by Michael Lewan (written communication, 1999) where used to calculate a "ball-park" thickness of mature source rock in the delta required to account for the amounts of recoverable petroleum in the

\footnotetext{
${ }^{3}$ Included in the mean volume of NGL.
} 
Agbada Assessment Unit. The calculations are based on a number of assumptions that are substantiated by data from the Niger Delta or other source rock studies. Regardless, the calculations are not intended to be a rigorous treatment of the data and are presented to test the feasibility of our estimates.

Assumptions:

1. Mature source rock (active pod occurs at depths great than $3 \mathrm{k}(\mathrm{Ro}=0.08 \%$; fig. 18, Chapter A).

2. Twenty-five per cent of oil expelled is lost as residual during secondary migration (based on a study of petroleum generated from the Albany Shale; Lewan and others, 1995).

3. Weight of naturally expelled oil is 5 times less than during Rock Eval pyrolysis (Lewan and others, 1995).

Measured or estimated parameters

1. Mean TOC used $=2.6 \mathrm{wt} \%$ ( $3.0 \mathrm{wt} \%$ median for USGS proprietary data; 2.2 $\mathrm{wt} \%$ average reported by Bustin, 1988; 2.3-2.5 wt\%; Udo and Ekweozor, 1988).

2. Mean Hydrogen Index used $=180 \mathrm{mg} \mathrm{HC} / \mathrm{g}$ TOC (181 median for USGS proprietary data; 90 average reported by Bustin, 1988; 232, Udo and others, 1988).

3. Mean source rock density used $=2.26$ (assumes $5 \%$ porosity).

4. Mean API used $=35\left(0.85 \mathrm{~g} / \mathrm{cm}^{3}\right)(55 \%$ of Niger delta oils have API gravity values between 30 and 40; Thomas, 1995).

5. Surface area of sediment in Agbada Assessment Unit at depths greater than 3 $\mathrm{km} \approx 100,000$ (from fig 8B, Chapter A).

6. Petroleum Resources for Assessment Unit $1($ discovered + undiscovered $)=$ 106 BBOE. $^{4}$

Calculations

1. Volume of resource (discovered + undiscovered) $=106 \times 10^{9} \mathrm{bbl}$

2. Volume of oil lost as residue $(25 \%)=35 \times 10^{9} \mathrm{bbl}$

3. Volume of oil expelled $=141 \times 10^{9} \mathrm{bbl}$

4. Mass of oil expelled $=\left(141 \times 10^{9} \mathrm{bbl}\right) \times\left(.159 \mathrm{~m}^{3} / \mathrm{bbl}\right)=2.24 \times 10^{10} \mathrm{~m}^{3}$ $=2.24 \times 10^{10} \mathrm{~m}^{3} \times\left(0.85 \mathrm{~g} / \mathrm{cm}^{3} \times 10^{6} \mathrm{~cm}^{3} / \mathrm{m}^{3}\right)=1.91 \times 10^{16} \mathrm{~g}$

5. Mass of mature TOC $=1.91 \times 10^{16} \mathrm{~g} /(((165 \mathrm{mg} / \mathrm{g}$ TOC $) / 5) / 1000 \mathrm{mg} / \mathrm{g})=$ $5.79 \times 10^{17} \mathrm{~g}$ TOC.

6. Mass of mature source rock $=\left(5.79 \times 10^{17} \mathrm{~g} \mathrm{TOC}\right) /(.026 \mathrm{~g}$ TOC $/ \mathrm{g}$ rock $)=$ $2.23 \times 10^{19} \mathrm{~g}$ rock

7. Volume of mature source rock = $\left(2.23 \times 10^{19} \mathrm{~g}\right.$ rock $) /\left(\left(2.26 \mathrm{~g} / \mathrm{cm}^{3}\right) \times\left(10^{6} \mathrm{~cm}^{3} / \mathrm{m}^{3}\right)=9.85 \times 10^{12} \mathrm{~m}^{3}\right.$

8. Source rock thickness $=9.85 \times 10^{12} \mathrm{~m}^{3} /\left(100,000 \mathrm{~km}^{2} \times 10^{6} \mathrm{~m}^{2} / \mathrm{km}^{2}\right)=99 \mathrm{~m}$.

\footnotetext{
${ }^{4}$ These resource estimates includes oil, gas, and NGL resources. The calculations do not take into account any differences between migration and expulsion efficiencies of oil versus gas.
} 
If our assumptions are reasonable, $100 \mathrm{~m}$ of mature source rock are needed to account for petroleum resources in Agbada Assessment Unit. The two assumptions with the most uncertainty are the percentage of petroleum lost to residue and the amount of hydrocarbons expelled from the rock. The numbers used in our calculations are means derived from experimental work on the New Albany Shale (Lewan and others, 1995). Assuming that $50 \%$ of the petroleum is lost as residual instead of $25 \%$, the thickness of shale required increases to $148 \mathrm{~m}$. Assuming the amount of hydrocarbons expelled is one-tenth that expelled during Rock Eval pyrolysis instead of one-fifth as used in the calculations, the thickness increases to $197 \mathrm{~m}$. Changing both to $50 \%$ and one-tenth respectively increases the thickness to $296 \mathrm{~m}$.

Our calculations indicate that a minimum of $100 \mathrm{~m}$ and no more than $300 \mathrm{~m}$ of mature source rock are required to account for the estimated recoverable resources of the Agbada Assessment Unit. These thicknesses can be accommodated reasonably either in the Agbada Formation where mature or easily in the mature upper Akata Formation.

\section{REFERENCES CITED IN CHAPTER B}

Attanasi, E.D. and Root, D.H., 1993, Statistics of petroleum exploration in the Caribbean, Latin America, Western Europe, the Middle East, Africa, Noncommunist Asia, and the Southwestern Pacific: U.S. Geological Survey Circular 1096, $129 \mathrm{p}$

Bustin, R. M., 1988, Sedimentology and characteristics of dispersed organic matter in Tertiary Niger Delta: origin of source rocks in a deltaic environment: American Association of Petroleum Geologists Bulletin, v. 72, p. 277-298.

Evamy, B.D., Haremboure, J., Kamerling, P., Knaap, W.A., Molloy, F.A., and Rowlands, P.H., 1978, Hydrocarbon habitat of Tertiary Niger Delta: American Association of Petroleum Geologists Bulletin, v. 62, p. 1-39.

Guardado, L.R., Gamboa, L.A.P., and Lucchesi, C.T., 1990, Petroleum geology of the Campos basin, Brazil, a model for a producing Atlantic type basin: AAPG Memoir 48. Tulsa, American Association of Petroleum Geologists, p. 3-79.

Klemme, H.D., 1975, Giant oil fields related to their geologic setting, a possible guide to exploration: Bulletin of Canadian Petroleum Geology, v. 23, p. 30-66.

Lewan, M.D., Comer, J.B., Hamilton-Smith, T., Hasenmueller, N.R., Guthrie, J.M., Hatch, J.R., Gautier, D.L., and Frankie, W.T., 1995, Feasibility study of material-balance assessment of Petroleum from the New Albany Shale in the Illinois Basin: U.S. Geological Survey Bulletin 2137, 31 p.

Schmoker, J.W., and Crovelli, R.A., 1998, A simplified spreadsheet program for estimating future growth of oil and gas reserves: Nonrenewable Resources, v. 7, no. 2, p. 149-155. 
Petroconsultants, 1996, Petroleum exploration and production database:

Houston, Texas, Petroconsultants, Inc., [database available from

Petroconsultants, Inc., P.O. Box 740619, Houston, TX 77274-0619].

Thomas, 1995, Markets slow to develop for Niger Delta gas reserves: Oil \& Gas Journal, November 27, 1995, p. 77-80.

Udo, O.T. and Ekweozor C.M., 1988, Comparative source rock evaluation of Opuama Channel Complex and adjacent producing areas of Niger delta: Nigerian Association of Petroleum Explorationists Bulletin, v. 3, no. 2, p. 10-27.

Udo, O.T., Ekweozor, C.M., and Okogun, J.I., 1988, Petroleum geochemistry of an ancient clay-filled canyon in the western Niger delta, Nigeria: Nigerian Association of Petroleum Explorationists Bulletin, v. 3, p. 8-25. 


\section{APPENDIX A}

Input for Monte Carlo simulations of the Agbada Reservoir Assessment Unit

Date:...28 May 1998

Assessment Geologist:...Michele L. Tuttle, Michael Brownfield, Ronald Charpentier

Region (name, no.):...Sub-Saharan Africa/Antartica, Region 7

Province Name:....Niger Delta

Province Number:...7192

Priority or Boutique?... Priority

Total Petroleum System (name, no.):... Cenozoic Niger Delta, 719201

Assessment Unit (name, no.)....Agbada Deltaic Reservoirs, 71920101

* Notes from Assessor

\section{CHARACTERISTICS OF ASSESSMENT UNIT}

Oil or Gas $(<20,000 \mathrm{cfg} / \mathrm{bbl}$ oil overall $): . .$. Oil

What is the minimum field size?......... 1 mmboe grown ( $\geq 1 \mathrm{mmboe})$

(the smallest field that has potential to be added to reserves in the next 30 years)

Number of discovered fields exceeding minimum size:.............. Established ( $>13$ fields) $\mathrm{X}$ Frontier (1-13 fields)

.........Oil: $\quad 481$ $\overline{\text { Hypothetical (no fields) }}$ 93

Median size (grown) of discovered oil fields (mmboe):

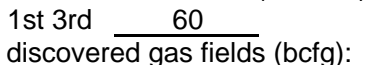

Median size (grown) of discovered gas fields (bcfg):

$$
1 \text { st } 3 \text { rd }
$$
116

\begin{tabular}{l} 
2nd 3rd $\quad 22$ \\
2nd 3rd $\quad 58$ \\
\hline
\end{tabular}

\begin{tabular}{lr} 
3rd 3rd & 23 \\
\cline { 2 - 2 } 3rd 3rd & 119 \\
\hline
\end{tabular}

Assessment-Unit Probabilities: Attribute Probability of occurrence $(0-1.0)$

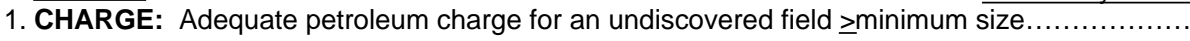

2. ROCKS: Adequate reservoirs, traps, and seals for an undiscovered field $\geq$ minimum size......

3. TIMING OF GEOLOGIC EVENTS: Favorable timing for an undiscovered field $\geq$ minimum size

\begin{tabular}{c}
$\frac{(0-1.0)}{1.0}$ \\
\hline 1.0 \\
\hline 1.0 \\
\hline
\end{tabular}

Assessment-Unit GEOLOGIC Probability (Product of 1, 2, and 3): 1.0

4. ACCESSIBILITY: Adequate location to allow exploration for an undiscovered field $\geq$ minimum size...

\section{UNDISCOVERED FIELDS}

Number of Undiscovered Fields: How many undiscovered fields exist that are $\geq$ minimum size?: (uncertainty of fixed but unknown values)

Oil fields: min. no. $(>0)$ min. no. $(>0)$

$\frac{200}{100}$ median no.

580

$\max$ no. $\frac{1000}{400}$

Gas fields:

Size of Undiscovered Fields: What are the anticipated sizes (grown) of the above fields?: (variations in the sizes of undiscovered fields)

Oil in oil fields (mmbo)

Gas in gas fields (bcfg):.

..min. size
...min. size

$\begin{array}{r}1 \\ \hline 6 \\ \hline\end{array}$
median size median size $\max$. size
$\max$ size $\max$ no. 400 


\section{AVERAGE RATIOS FOR UNDISCOVERED FIELDS, TO ASSESS COPRODUCTS}

(uncertainty of fixed but unknown values)

\begin{tabular}{|c|c|c|c|}
\hline $\begin{array}{l}\text { Oil Fields: } \\
\text { Gas/oil ratio }(\mathrm{cfg} / \mathrm{bbl} \text { oil) } \ldots \ldots \ldots \ldots \ldots \ldots \ldots \ldots \ldots \ldots \ldots \ldots \ldots \ldots \ldots \ldots \ldots \ldots \ldots \ldots \ldots \ldots \ldots \ldots \ldots \ldots\end{array}$ & $\begin{array}{c}\text { minimum } \\
1000 \\
20 \\
\end{array}$ & $\begin{array}{c}\text { mean } \\
1770 \\
34 \\
\end{array}$ & $\begin{array}{c}\text { maximum } \\
3000 \\
45\end{array}$ \\
\hline $\begin{array}{l}\text { Gas fields: } \\
\text { Total liquids/gas ratio (bbl ngl/mmcfg).. }\end{array}$ & $\begin{array}{l}\text { minimum } \\
50\end{array}$ & $\begin{array}{c}\text { mean } \\
61\end{array}$ & $\begin{array}{l}\text { maximum } \\
70 \\
\end{array}$ \\
\hline \multicolumn{4}{|c|}{$\begin{array}{l}\text { SELECTED ANCILLARY DATA FOR UNDISCOVERED FIELDS } \\
\text { (variations in the properties of undiscovered fields) }\end{array}$} \\
\hline 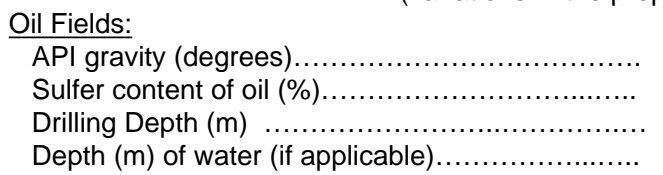 & $\begin{array}{c}\text { minimum } \\
10 \\
0.07 \\
350 \\
0\end{array}$ & $\begin{array}{c}\text { median } \\
40 \\
0.15 \\
2100 \\
40 \\
\end{array}$ & $\begin{array}{c}\text { maximum } \\
60 \\
0.60 \\
4500 \\
200 \\
\end{array}$ \\
\hline $\begin{array}{l}\text { Gas Fields: } \\
\text { Inert gas content }(\%) \ldots \ldots \ldots \ldots \ldots \ldots \ldots \ldots \ldots \ldots \ldots \ldots \ldots \ldots \ldots \ldots \ldots\end{array}$ & $\begin{array}{l}\text { minimum } \\
\text { low }\end{array}$ & median & maximum \\
\hline $\begin{array}{l}\mathrm{CO}_{2} \text { content }(\%) \ldots \ldots \ldots \ldots \ldots \ldots \ldots \ldots \ldots \ldots \ldots \ldots \\
\text { Hydrogen-sulfide content }(\%) \ldots \ldots \ldots \ldots \ldots \ldots \ldots \ldots \ldots \ldots \ldots \ldots \ldots \ldots \ldots \ldots\end{array}$ & $\frac{\text { low }}{\text { low-nil }}$ & & \\
\hline Drilling Depth $(\mathrm{m})$.................................. & 680 & 2200 & 4500 \\
\hline Depth $(\mathrm{m})$ of water (if applicable) .......................... & 0 & 40 & 200 \\
\hline
\end{tabular}

ALLOCATION OF UNDISCOVERED RESOURCES IN THE ASSESSMENT UNIT

TO COUNTRIES OR OTHER LAND PARCELS (uncertainty of fixed but unknown values)

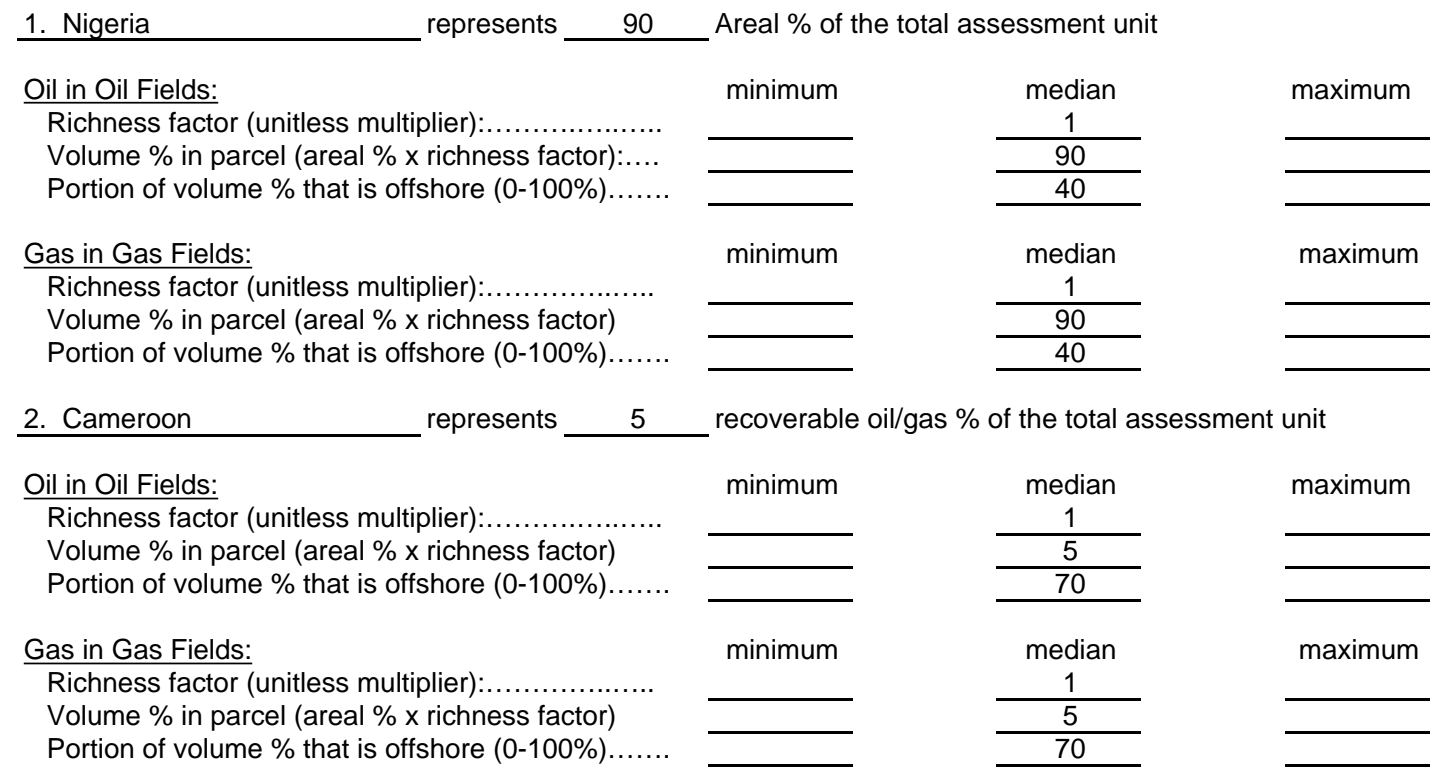

*Uncertainty about this mean will be calculated using statistical methods 
areal $\%$ of the total assessment unit

Oil in Oil Fields:

Richness factor (unitless multiplier):...

Volume \% in parcel (areal \% x richness factor)

Portion of volume $\%$ that is offshore $(0-100 \%)$

Gas in Gas Fields:

Richness factor (unitless multiplier):.

Volume \% in parcel (areal \% x richness factor)

Portion of volume $\%$ that is offshore $(0-100 \%) \ldots . . .$. minimum

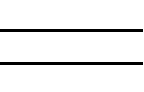

minimum

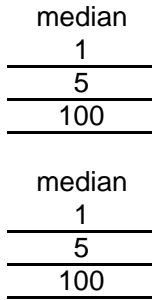

maximum

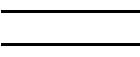

maximum

$\overline{ }$ 
Date:...28 May 1998

Assessment Geologist:...Michele L. Tuttle, Michael Brownfield, Ronald Charpentier

Region (name, no.):...Sub-Saharan Africa/Antartica, Region 7

Province Name:....Niger Delta

Province Number:...7192

Priority or Boutique?... Priority

Total Petroleum System (name, no.):... Cenozoic Niger Delta, 719201

Assessment Unit (name, no.):...Akata Turbidite Reservoirs, 71920102

* Notes from Assessor

\section{CHARACTERISTICS OF ASSESSMENT UNIT}

Oil or Gas $(<20,000 \mathrm{cfg} / \mathrm{bbl}$ oil overall):

oil

What is the minimum field size?......... $\quad 1 \quad$ mmboe grown ( $>1 \mathrm{mmboe})$

(the smallest field that has potential to be added to reserves in the next 30 years)

Number of discovered fields exceeding minimum size:............. Established (>13 fields)

Frontier (1-13 fields)

........... Oi : Oil: $\frac{\mathrm{X}}{\text { Hypothetical (no fields) }}$ Hypothetical (no fields) $\mathrm{X}$

Median size (grown) of discovered oil fields (mmboe): 1st 3rd 2nd 3rd 3rd 3rd

Median size (grown) of discovered gas fields (bcfg): 1 st 3rd

2nd 3rd

3rd 3rd

\section{Assessment-Unit Probabilities:}

Attribute

Probability of occurrence (0-1.0)

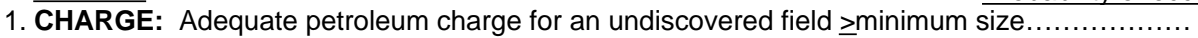

2. ROCKS: Adequate reservoirs, traps, and seals for an undiscovered field $\geq$ minimum size......

3. TIMING OF GEOLOGIC EVENTS: Favorable timing for an undiscovered field $\geq$ minimum size

\begin{tabular}{c}
1.0 \\
\hline 1.0 \\
\hline 1.0
\end{tabular}

Assessment-Unit GEOLOGIC Probability (Product of 1, 2, and 3): 1.0

4. ACCESSIBILITY: Adequate location to allow exploration for an undiscovered field $\geq$ minimum size

\section{UNDISCOVERED FIELDS}

Number of Undiscovered Fields: How many undiscovered fields exist that are $\geq$ minimum size?: (uncertainty of fixed but unknown values)

Oil fields:. $\min$. no. $(>0)$ min. no. $(>0)$

10

median no. median no. max no. $\quad 500$ $\max$ no. 200

Size of Undiscovered Fields: What are the anticipated sizes (grown) of the above fields?: (variations in the sizes of undiscovered fields)

Oil in oil fields (mmbo)

...min. size

$\frac{1}{6}$

median size

23

Gas in gas fields (bcfg):

...min. size

median size

60

max. size $\quad 3000$

max. size

3500


AVERAGE RATIOS FOR UNDISCOVERED FIELDS, TO ASSESS COPRODUCTS

(uncertainty of fixed but unknown values)

\begin{tabular}{|c|c|c|c|}
\hline \multirow[b]{2}{*}{ Oil Fields: } & \multicolumn{2}{|c|}{ 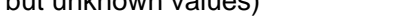 } & \multirow[b]{2}{*}{ maximum } \\
\hline & minimum & mean & \\
\hline Gas/oil ratio (cfg/bbl oil).......... & 1000 & 2000 & 3000 \\
\hline NGL/gas ratio (bbl ngl/mmcfg)........ & 20 & 40 & 45 \\
\hline Gas fields: & minimum & mean & maximum \\
\hline Total liquids/gas ratio (bngl/mmcfg).. & 50 & 61 & 70 \\
\hline
\end{tabular}

\section{SELECTED ANCILLARY DATA FOR UNDISCOVERED FIELDS}

(variations in the properties of undiscovered fields)

Oil Fields:

\begin{tabular}{c}
$\frac{\text { minimum }}{20}$ \\
\hline 0.07 \\
\hline 800 \\
\hline 0 \\
\hline
\end{tabular}

median

API gravity (degrees).

Sulfur content of oil $(\%)$

Drilling Depth $(\mathrm{m})$

Depth $(m)$ of water (if applicable)

\begin{tabular}{c}
$\begin{array}{c}\text { minimum } \\
\text { low }\end{array}$ \\
$\frac{\text { low }}{\text { low-nil }}$ \\
\hline 800 \\
\hline 0 \\
\hline
\end{tabular}

maximum

60

0.60

6500

4000

\section{Gas Fields:}

Inert gas content (\%)

$\mathrm{CO}_{2}$ content $(\%)$.

Hydrogen-sulfide content(\%)

Drilling Depth $(\mathrm{m})$

Depth $(m)$ of water (if applicable)

ALLOCATION OF UNDISCOVERED RESOURCES IN THE ASSESSMENT UNIT TO COUNTRIES OR OTHER LAND PARCELS (uncertainty of fixed but unknown values)

\begin{tabular}{|c|c|c|c|}
\hline 1. Nigeria represents $\quad 94$ & \multicolumn{2}{|c|}{ areal $\%$ of the total assessment unit } & \multirow[b]{2}{*}{ maximum } \\
\hline Oil in Oil Fields: & minimum & median & \\
\hline Richness factor (unitless multiplier).$\ldots \ldots \ldots \ldots \ldots \ldots \ldots$ & & 1 & \\
\hline Volume $\%$ in parcel (areal $\%$ x richness factor):.... & & 94 & \\
\hline Portion of volume $\%$ that is offshore $(0-100 \%) \ldots \ldots$ & & 80 & \\
\hline Gas in Gas Fields: & minimum & median & maximum \\
\hline Richness factor (unitless multiplier) $\ldots \ldots \ldots \ldots \ldots \ldots \ldots \ldots \ldots$ & & 1 & \\
\hline Volume $\%$ in parcel (areal $\%$ x richness factor) $: . .$. & & 94 & \\
\hline Portion of volume $\%$ that is offshore $(0-100 \%) \ldots \ldots$ & & 80 & \\
\hline 2. Cameroon & \multicolumn{2}{|c|}{ areal $\%$ of the total assessment unit } & \\
\hline Oil in Oil Fields: & minimum & median & maximum \\
\hline Richness factor (unitless multiplier).$\ldots \ldots \ldots \ldots \ldots \ldots \ldots \ldots \ldots \ldots$ & & 0.5 & \\
\hline Volume $\%$ in parcel (areal $\%$ x richness factor):.... & & 1 & \\
\hline Portion of volume $\%$ that is offshore $(0-100 \%) \ldots \ldots$ & & 70 & \\
\hline Gas in Gas Fields: & minimum & median & maximum \\
\hline Richness factor (unitless multiplier) $\ldots \ldots \ldots \ldots \ldots \ldots \ldots$ & & 0.5 & \\
\hline Volume $\%$ in parcel (areal $\%$ x richness factor) $\ldots . .$. & & 1 & \\
\hline Portion of volume $\%$ that is offshore $(0-100 \%) \ldots \ldots$. & & 70 & \\
\hline
\end{tabular}

*Uncertainty about this mean will be calculated using statistical methods 
areal $\%$ of the total assessment unit

Oil in Oil Fields:

Richness factor (unitless multiplier):.

Volume $\%$ in parcel (areal $\%$ x richness factor):.....

Portion of volume $\%$ that is offshore $(0-100 \%) \ldots \ldots$...

Gas in Gas Fields:

Richness factor (unitless multiplier):

Volume $\%$ in parcel (areal \% $\mathrm{x}$ richness factor):....

Portion of volume $\%$ that is offshore $(0-100 \%) \ldots \ldots$.

\begin{tabular}{c} 
minimum \\
\hline minimum \\
\hline \\
\hline
\end{tabular}

maximum

0.8

3.2

median

0.8

3.2

100

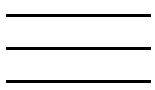

maximum 

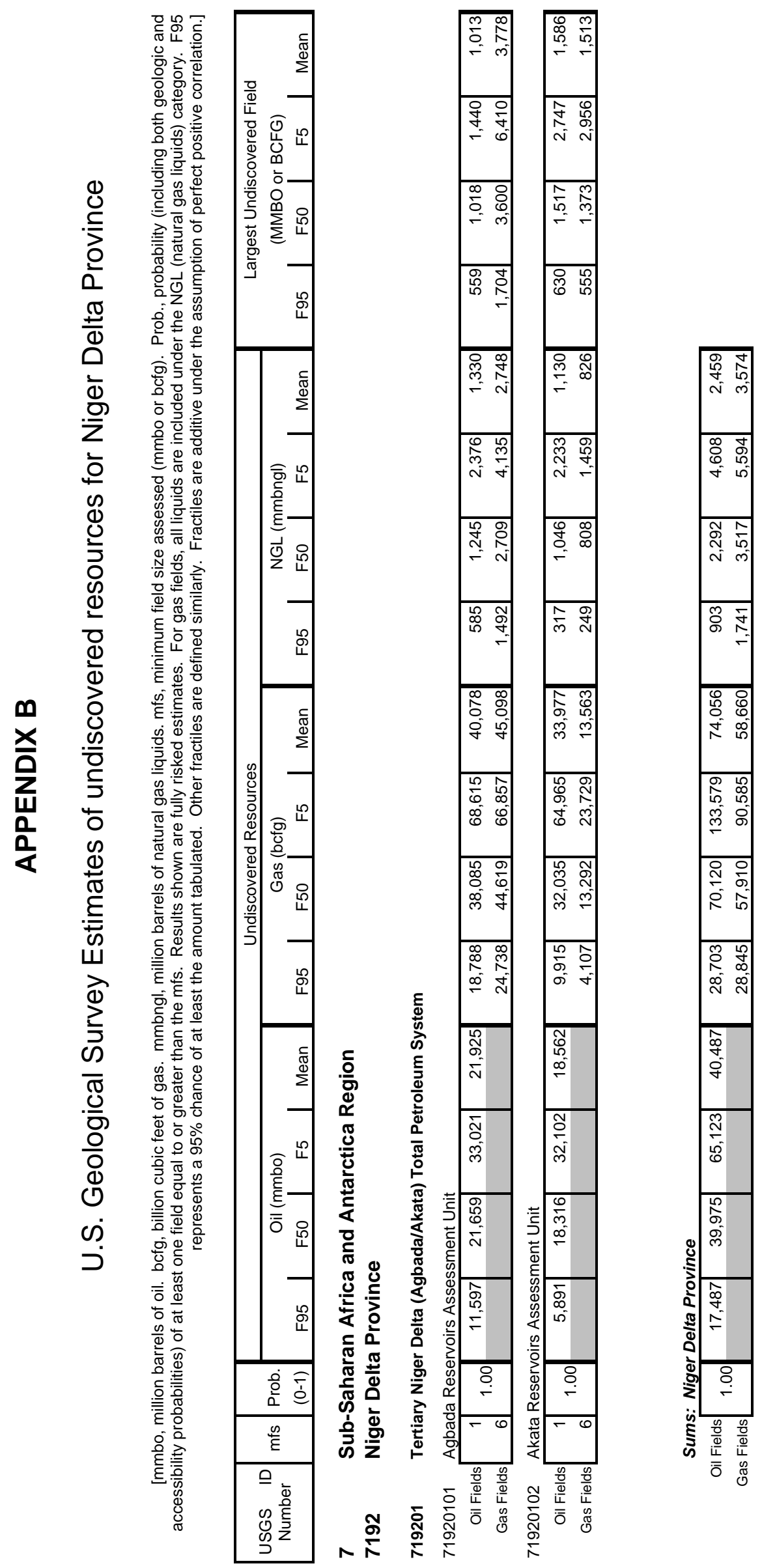